\title{
REABILITAÇÃO DE PAREDES DE ALVENARIA PELA APLICAÇÃO DE REVESTIMENTOS RESISTENTES DE ARGAMASSA ARMADA
}

\section{Fabiana Lopes de Oliveira}

Tese Apresentada à Escola de Engenharia de São Carlos, da Universidade de São Paulo, como parte dos requisitos para obtenção do título de Doutor em Engenharia de Estruturas.

ORIENTADOR: Prof. Titular João Bento de Hanai

São Carlos

2001 
Oliveira, Fabiana Lopes de

O47r Reabilitação de paredes de alvenaria pela aplicação de revestimentos resistentes de argamassa armada / Fabiana Lopes de Oliveira. -- São Carlos, 2001.

203p.

Tese (Doutorado) -- Escola de Engenharia de São CarlosUniversidade de São Paulo, 2001.

Orientador: Prof.Titular João Bento de Hanai

1. Reabilitação de estruturas de alvenaria. 2. Argamassa armada. I. Título. 
Pai, não poderia deixar de dedicarte mais essa vitória. É muito prazeroso te ter como pai, amigo e companheiro na vida. 


\section{AGRADECIMENTOS}

A Deus pelo amor incondicional que nos oferece. Obrigada pela perseverança e força durante todo esse período. "Que o teu coração deposite toda a sua confiança no Senhor! Não te firmes em tua própria sabedoria! Sejam quais forem os teus caminhos, pensa nele, e ele aplainará tuas sendas." Provérbios 3:5-6.

Ao Prof. João Bento de Hanai pela valiosa dedicação, amizade e incentivo dedicados durante todo esse tempo. Obrigada pelas idéias brilhantes que enriqueceram este trabalho e pela orientação sempre tão firme e segura. Considerote uma referência profissional para qualquer pesquisador.

Ao CNPQ (Conselho Nacional de Desenvolvimento Científico e Tecnológico) pela bolsa de Doutorado concedida durante os primeiros meses do Doutorado.

À FAPESP (Fundação de Amparo à Pesquisa de Estado de São Paulo) pela bolsa de Doutorado e por proporcionar toda condição necessária para o desenvolvimento da pesquisa.

Aos meus pais, saudade constante nessa jornada. Obrigada por terem me dado as bases emocionais e morais para o desenvolvimento de todos os projetos de minha vida.

Aos Professores Márcio Ramalho e Márcio Corrêa pela atenção, esclarecimento de dúvidas e amizade. Admiro muito vocês.

A GLASSER - Pisos e Pré-Moldados Ltda. e a TATU - Pré-Moldados pelos blocos concedidos para os ensaios. Vocês poderão não ver o resultado da doação em forma de edifícios, casas ou galpões mas sim, no enriquecimento da pesquisa, do conhecimento técnico e profissional trazendo benefícios para futuras construções de alvenaria. 
Aqui vai um agradecimento especialíssimo ao Prof. TAKEYA não só pela ajuda técnica, sempre muito significativa, mas também pelo eterno sorriso, educação e boa vontade que sempre me recebeu.

Aos funcionários do Laboratório de Estruturas da EESC (Amaury, João, Jorge, Luiz, Mário, Mauri, Ricardo e Valdir) pelo help nos ensaios realizados. Foram muitos ensaios, inúmeras horas de trabalho e de muita conversa também. Obrigada pela amizade e profissionalismo de vocês.

A Marta, Nadir e Rosi pela amizade sincera e consideração sempre demonstrada. Vocês "quebraram vários galhos" para mim. Vocês são simplesmente D+.

A todos os colegas, professores e funcionários do Departamento de Estruturas da Escola de Engenharia de São Carlos, pela ajuda, convívio e amizade durante todo esse período. 


\section{SUMÁRIO}

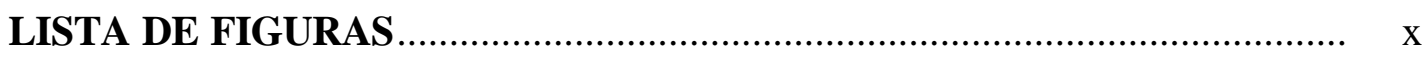

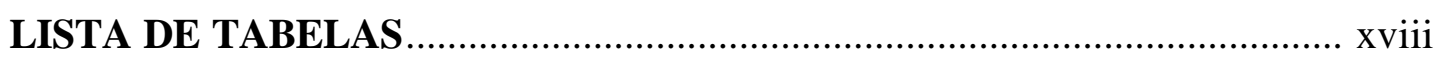

RESUMO

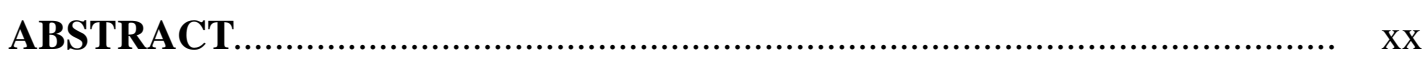

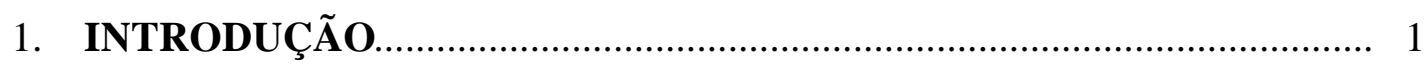

2. PATOLOGIA NAS ALVENARIAS E SUA REABILITAÇÃO................ 7

2.1 Patologia nas alvenarias de vedação.................................................... 8

2.2 Patologia nas alvenarias estruturais.................................................. 12

2.3 Reabilitação das alvenarias.......................................................... 16

3. O USO DE REVESTIMENTOS RESISTENTES NA REABILITAÇÃO DE ESTRUTURAS DE ALVENARIA ............................................ 22

\section{METODOLOGIA APLICADA PARA O DESENVOLVIMENTO}

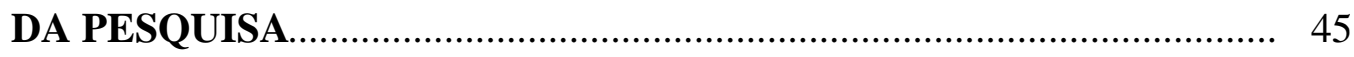

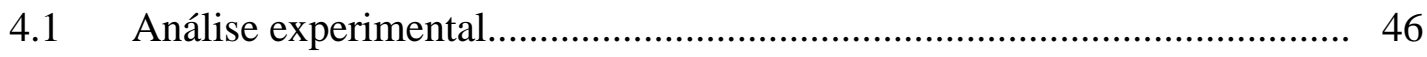

4.1.1 Ensaios de compressão axial........................................................... 46

4.1.2 Ensaios de compressão diagonal......................................................... 57

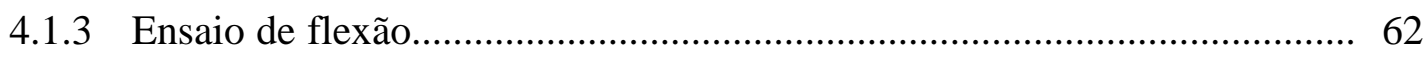

4.1.4 Ensaios de protótipos com abertura........................................................ 63

4.2 Análise teórica.................................................................................. 64

4.2.1 Comportamento de paredes submetidas à compressão axial...................... 64

4.2.2 Compressão diagonal..................................................................... 71

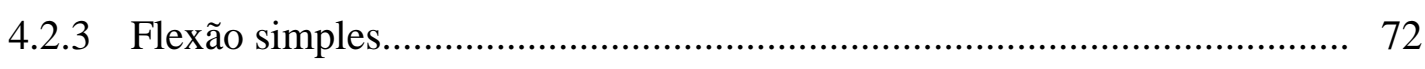

4.2.4 Análise numérica.............................................................................. 73

5. ENSAIOS DE PAREDES DE ALVENARIA SUBMETIDAS

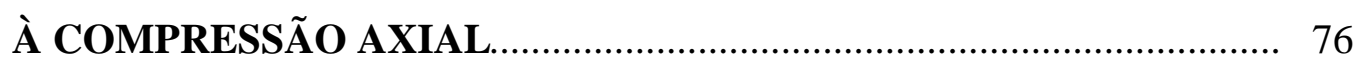

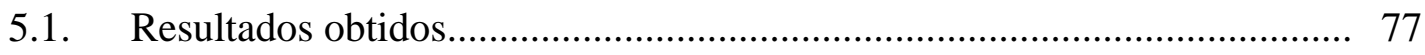

a) Paredes P01 e P02 (sem revestimento)..................................................... 77 
b) Paredes P03 e P04 (revestidas com argamassa "fraca")........................... 77

c) Paredes P05 e P06 (revestidas com argamassa "forte")............................ 78

d) Paredes P07 e P08 (revestidas com argamassa "forte" + telas soldadas)... 78

e) Paredes P09 e P10 (revestidas com argamassa "forte" + telas soldadas conectores 1 - telas nas juntas e no plano da parede)............................... 78

f) Paredes P11 e P12 (revestidas com argamassa "fraca" + fibras de

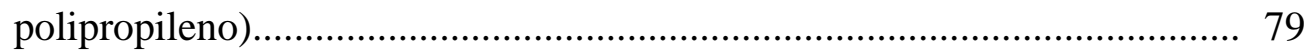

g) Paredes P13 e P14 (revestidas com argamassa "forte" + fibras de aço)..... 79

h) Paredes P15 e P16 (revestidas com argamassa "forte" + telas soldadas + conectores 2) .............................................................................. 80

5.2 Análise dos resultados...................................................................... 89

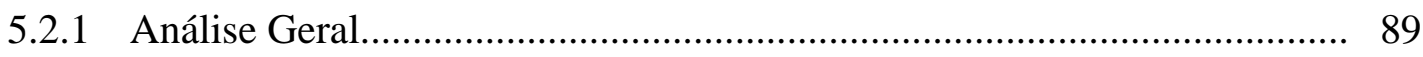

5.2.2 Paredes sem revestimento............................................................... 91

5.2.3 Desenvolvimento de uma formulação teórico-experimental de referência........................................................................................... 93

5.2.4 Paredes revestidas com argamassa simples.......................................... 96

5.2.4 Paredes revestidas com argamassa com fibras....................................... 98

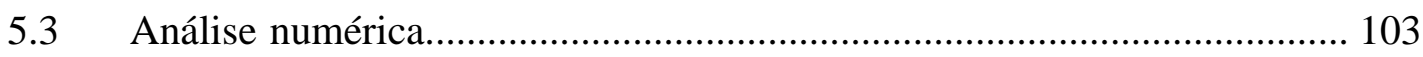

5.4 Conclusões parciais dos ensaios de compressão axial............................... 112

6. ENSAIOS DE PAREDES DE ALVENARIA SUBMETIDAS À

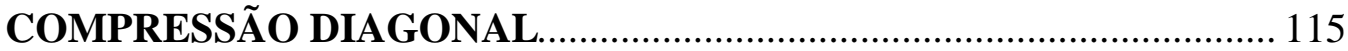

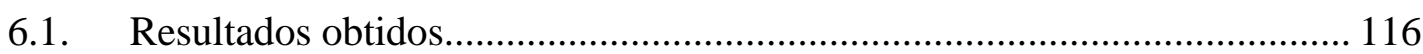

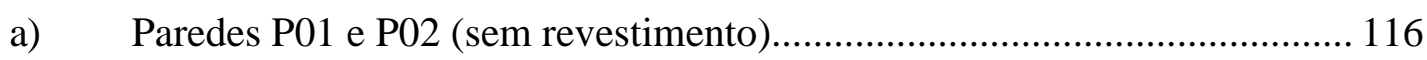

b) Paredes P03 e P04 (revestidas com argamassa "fraca")............................ 117

c) Paredes P05 e P06 (revestidas com argamassa "forte")...............................117

d) Paredes P07 e P08 (revestidas com argamassa "fraca" + fibras de polipropileno)

e) Paredes P09 e P10 (revestidas com argamassa "forte" + fibras de aço)...... 118

f) Paredes P11 e P12 (revestidas com argamassa "forte" + telas soldadas).... 118

g) Paredes P13 e P14 (revestidas com argamassa "forte" + telas soldadas nas faces e nas juntas da parede). 
h) Paredes P15 e P16 (revestidas com argamassa "forte" + telas soldadas + conectores 2).

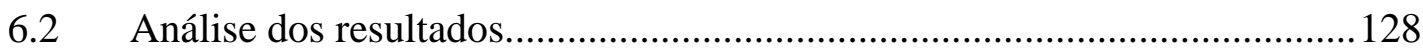

6.3 Conclusões parciais dos ensaios de compressão diagonal........................... 137

7. ENSAIOS DE PAREDES DE ALVENARIA SUBMETIDAS À FLEXÃO. 139

7.1. Resultados obtidos. 140

a) Paredes P01 e P02 - revestidas com argamassa "forte" + telas soldadas (situação 1 de carregamento). 140

b) Paredes P03 (situação 1 de carregamento) e P04 (situação 2 de carregamento) - revestidas com argamassa "forte" + telas soldadas + conectores tipo 1 140

c) Paredes P05 (situação 1 de carregamento) e P06 (situação 2 de carregamento) - revestidas com argamassa "forte" + telas soldadas + conectores tipo 2 141

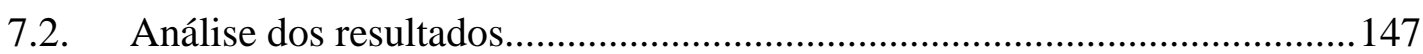

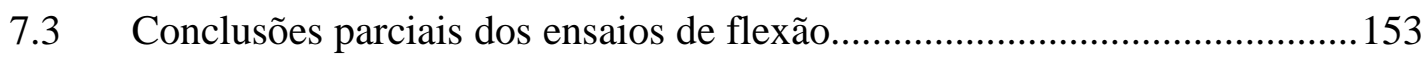

8. ENSAIOS DE PAREDES COM ABERTURA ….................................. 155

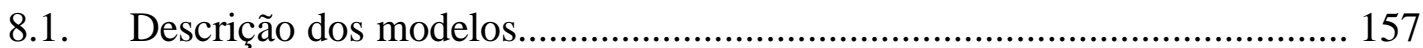

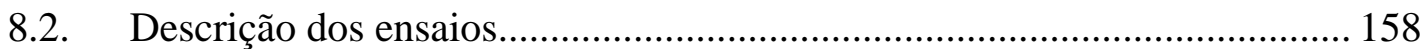

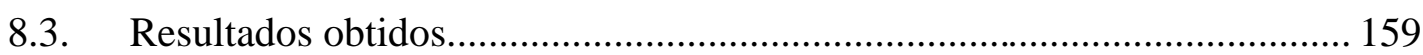

a) Parede P01 (sem revestimento),.............................................................. 159

b) Parede P02 (revestida sem danificação prévia)......................................... 160

c) Parede P03 (sem revestimento).............................................................. 160

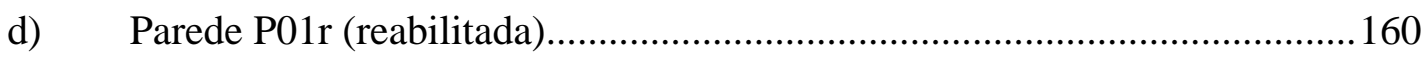

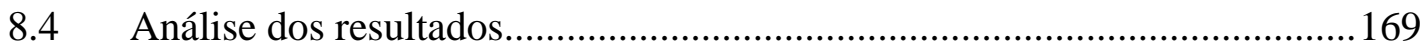

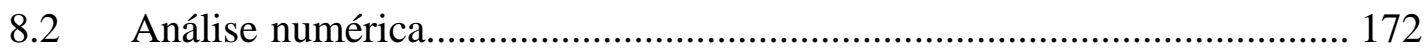

8.3 Conclusões parciais..................................................................... 184 
9. CONCLUSÕES 185

9.1 Sobre a técnica de reabilitação e o comportamento geral das paredes. .185

9.2 Sobre a metodologia geral de análise. 187

9.3 Sobre o comportamento na compressão axial................................................ 189

9.4 Sobre o comportamento na compressão diagonal............................................ 192

9.5 Sobre o comportamento na flexão..................................................................... 193

9.6 Sobre o comportamento misto nas paredes com abertura................................. 193

9.7 Desenvolvimento de pesquisas futuras............................................................ 194

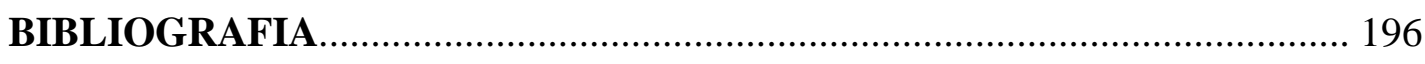

ANEXO A - Resultados dos ensaios das paredes submetidas à compressão axial.

ANEXO B - Resultados dos ensaios das paredes submetidas à compressão diagonal.

ANEXO C - Resultados dos ensaios das paredes submetidas à flexão.

ANEXO D - Resultados dos ensaios das paredes com aberturas.

ANEXO E - Resultados da análise teórica (formulação aditiva). 


\section{LISTA DE FIGURAS}

Figura 1.1 - Ensaio de compressão axial...................................................................... 4

Figura 1.2 - Ensaio de compressão.................................................................................. 4

Figura 1.3 - Ensaio de flexão.................................................................................... 5

Figura 2.1 - Flecha da viga superior igual à da viga inferior porém maior que a alvenaria suporta - adaptada de PFEFFERMANN (1968)...

Figura 2.2 - Flecha da viga inferior é maior que a da viga superior - adaptada de PFEFFERMANN (1968)

Figura 2.3 - Flecha da viga inferior é menor que a da viga superior - adaptada de PFEFFERMANN (1968).

Figura 2.4 - Ruptura seccionando os componentes de alvenaria. Argamassa mais resistente que o bloco e aderência adequada.

Figura 2.5 - Ruptura em forma de escada. Argamassa menos resistente que o bloco, com módulo de elasticidade elevado e/ou má aderência ao bloco..

Figura 2.6 - Argamassa menos resistente que o bloco, com baixo módulo de elasticidade e aderência adequada.

Figura 2.7 - Fissuração oriunda de sobrecarregamentos - adaptada de THOMAZ, 1990.

Figura 2.8 - Fissuração em paredes com aberturas - adaptada de THOMAZ, 1990.

Figura 2.9 - Fissura horizontal na base da alvenaria causada por flexo-compressão adaptada de THOMAZ, 1990.

Figura 2.10 - Fissura horizontal na base da alvenaria causada por movimentações higroscópicas - adaptada de THOMAZ, 1990.

Figura 2.11 - Fissuras de cisalhamento na alvenaria. FONTE: THOMAZ (1990)........... 14

Figura 2.12 - Recalque diferenciado da fundação - adaptada de THOMAZ, 1990......... 15

Figura 2.13 - Fundação contínua solicitada por carregamento desbalanceado................... 15

Figura 2.14 - Sob a abertura surgem fissuras por flexão................................................... 16

Figura 2.15 - Desvinculação entre a parede fissurada e o componente estrutural superior - extraída de THOMAZ, 1989..................................................... 18

Figura 2.16- Recuperação de destacamento entre pilar e parede....................................... 19

Figura 2.17 - Recuperação com bandagem.................................................................... 20

Figura 2.18 - Reforço de alvenaria portante com tirante de aço....................................... 20

Figura 3.1 - Parede não revestida........................................................................ 23

Figura 3.2 - Parede revestida............................................................................. 24

Figura 3.3 - Esquema do ensaio de compressão diagonal................................................... 24 
Figura 3.4 - Resultados dos ensaios - extraída de REINHORN \& PRAWEL, 1991

Figura 3.5 - Gráfico força x deslocamento dos ensaios realizados, extraído de SINGH et al. (1988).

Figura 3.6 - Fissuras observadas nas faces laterais dos blocos das paredes nãorevestidas.

Figura 3.7 - Tipos de fissuras encontradas nas paredes revestidas - extraída de CAVALHEIRO \& MÜLLER (1991).

Figura 3.8 - Fissuras que ocasionavam o descolamento do revestimento - extraída de CAVALHEIRO \& MÜLLER (1991)

Figura 3.9 - Descrição dos modelos ensaiados (com telas) - extraída de IRIMIES \& CRAINIC (1993).

Figura 3.10 - Fissuração das paredes ensaiadas - extraída de IRIMIES \& CRAINIC (1993)

Figura 3.11 - Gráfico força x deslocamento das paredes P1 e P1s 34

Figura 3.12 - Gráfico força x deslocamento das paredes P2 e P2s 35

Figura 3.13 - Reforço utilizados nas paredes - adaptada de JABAROV et al. (1985).

Figura 3.14 - Modelo ensaiado sem revestimento - extraída de JABAROVet al. (1985)

Figura 3.15 - Modelo ensaiado com reforço nas paredes 1 e 2 (barras diagonais) extraída de JABAROV et al. (1985)

Figura 3.16 - Modelo ensaiado com reforço na parede 3 (telas soldadas) - extraída de JABAROV et al. (1985).

Figura 3.17 - Aplicação do revestimento nos painéis - extraída de KAHN, L F. (1984).

Figura 3.18 - Modelo sem revestimento

Figura 3.19 - Modelo reabilitado.

Figura 3.20 - Modelo M0.

Figura 3.21 - Modelo M1

Figura 3.22 - Modelo M2.

Figura 3.23 - Modelo M3.

Figura 3.24 - Exemplo de aplicação dos compósitos de fibras - extraída de EHSANI \& SAADATMANESH (1996)

Figura 3.25 - Gráfico tensão - deformação dos compósitos analisados - EHSANI \& SAADATMANESH (1996)

Figura 4.1 - Situação 1 46

Figura 4.2 - Situação 2 46

Figura 4.3 - Situação 3 46

Figura 4.4 - Esquema do ensaio à compressão simples de paredes de alvenaria. 47 


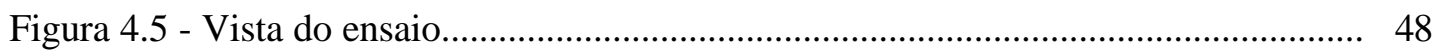

Figura 4.6 - Colocação das telas.................................................................................. 48

Figura 4.7 - Diagramas Força x Encurtamento médio da parede...................................... 50

Figura 4.8 - Vista dos modelos da $2^{\mathrm{a}}$ série de ensaios................................................... 53

Figura 4.9 - Vista de frente................................................................................ 54

Figura 4.10 - Vista lateral................................................................................. 54

Figura 4.11 - Vista de cima............................................................................... 54

Figura 4.12 - Execução das paredes com o gabarito.......................................................... 55

Figura 4.13 - Vista das paredinhas sendo confeccionadas................................................ 55

Figura 4.14 - Esquema do ensaio...................................................................... 56

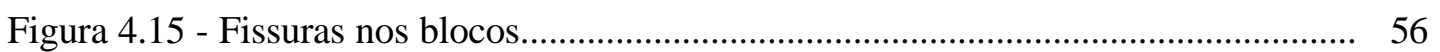

Figura 4.16 - Fissura na argamassa prolongada no bloco............................................. 56

Figura 4.17 - Gráfico força $\mathrm{x}$ encurtamento da paredinha piloto....................................... 57

Figura 4.18 - Gabarito de madeira................................................................................ 58

Figura 4.19 - Esquema do ensaio............................................................................. 58

Figura 4.20 - Dimensão das sapatas....................................................................... 58

Figura 4.21 - Transporte do modelo............................................................................ 59

Figura 4.22 - Modelo no equipamento de ensaio............................................................ 59

Figura 4.23 - Colocação de massa plástica na sapata de apoio........................................... 60

Figura 4.24 - Esquema do ensaio............................................................................... 61

Figura 4.25 - Ruptura na interface tijolo-argamassa..................................................... 61

Figura 4.26 - Gráfico força $\mathrm{x}$ deslocamento da paredinha piloto..................................... 61

Figura 4.27 - Ensaio com carga aplicada no vão................................................................ 62

Figura 4.28 - Ensaio com carga aplicada nos terços do vão............................................... 63

Figura 4.29 - Vista dos protótipos com abertura................................................................. 64

Figura 4.30 - Representação do Modelo de Reuss............................................................... 68

Figura 4.31 - Representação do modelo de Voigt............................................................... 69

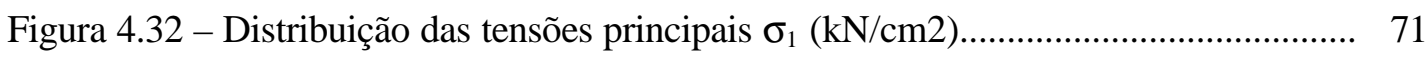

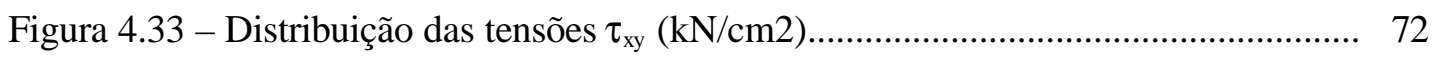

Figura 4.34 - Elemento SOLID 95 ....................................................................... 74

Figura 4.35 - Elemento SOLID 65 .......................................................................... 74

Figura 4.36 - Elemento bidimensional PLANE 42 _................................................. 75

Figura 5.1 - Ruptura da parede P01 ........................................................................ 81

Figura 5.2 - Ruptura da parede P02 ........................................................................ 81

Figura 5.3 - Gráfico força x encurtamento médio das paredes P01 e P02........................ 81 


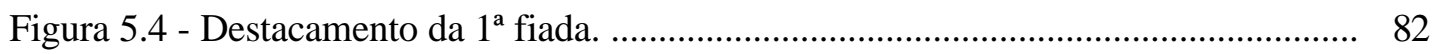

Figura 5.5 - Ruptura dos septos............................................................................. 82

Figura 5.6 - Gráfico força x encurtamento médio da parede P03 ..................................... 82

Figura 5.7 - Ruptura da parede P05 ......................................................................... 83

Figura 5.8 - Ruptura da parede P06..................................................................... 83

Figura 5.9 - Gráfico força x encurtamento médio das paredes P05 e P06......................... 83

Figura 5.10 - Ruptura dos septos dos blocos da parede P07 ............................................ 84

Figura 5.11 - Ruptura dos septos dos blocos da parede P08 ............................................ 84

Figura 5.12 - Gráfico força x encurtamento médio das paredes P07 e P08....................... 84

Figura 5.13 - Fissuras horizontais na parede P09...................................................... 85

Figura 5.14 - Ruptura da parede P10 .................................................................... 85

Figura 5.15 - Gráfico força x encurtamento médio das paredes P09 e P10....................... 85

Figura 5.16 - Fissuras na parte superior da parede.............................................................. 86

Figura 5.17 - Fissura nos septos dos blocos da parede P11 .............................................. 86

Figura 5.18 - Gráfico força x encurtamento médio das paredes P11 e P12....................... 86

Figura 5.19 - Ruptura da parede P13 ..................................................................... 87

Figura 5.20 - Fissuras verticais no revestimento da parede P14 ....................................... 87

Figura 5.21 - Gráfico força x encurtamento médio das paredes P13 e P14 ....................... 87

Figura 5.22 - Destacamento do revestimento da parede P15 .......................................... 88

Figura 5.23 - Abaulamento do núcleo destacando-se do revestimento.............................. 88

Figura 5.24 - Gráfico força x encurtamento médio das paredes P15 e P16...................... 88

Figura 5.25 - Gráfico força $x$ encurtamento das paredinhas ensaiadas à compressão

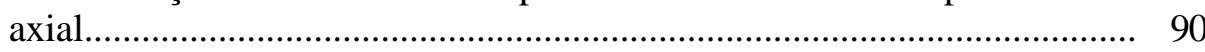

Figura 5.26 - Gráfico força x encurtamento das paredes sem revestimento...................... 93

Figura 5.27 - Gráfico força x encurtamento das paredes revestidas com argamassa simples.

Figura 5.28 - Gráfico tensão x deformação da parede sem revestimento e das argamassas simples do revestimento.

Figura 5.29 - Gráficos força x deslocamento da parede sem revestimento (experimental) e dos revestimentos de argamassa simples (teóricos).......... 96

Figura 5.30 - Gráficos força x deslocamento da parede sem revestimento e dos revestimentos de argamassas simples, depois da interpolação..

Figura 5.31 - Gráficos das paredes revestidas com argamassa simples e da formulação aditiva.

Figura 5.32 - Gráficos das paredes revestidas com argamassa fraca e fibras de polipropileno e da formulação aditiva.

Figura 5.33 - Gráficos das paredes revestidas com argamassa forte e fibras de aço e da formulação aditiva. 
Figura 5.34 - Gráficos das paredes revestidas com argamassa forte e telas soldadas e da formulação aditiva

Figura 5.35 - Gráficos das paredes revestidas com argamassa forte + telas soldadas + conectores1 e da formulação aditiva. 102

Figura 5.36 - Gráficos das paredes revestidas com argamassa forte + telas soldadas + conectores 2 e da formulação aditiva. 102

Figura 5.37 - Parede analisada. 104

Figura 5.38 - Malha discretizada. 104

Figura 5.39 - Deslocamento na direção y.................................................................... 105

Figura 5.40 - Deformação na direção y........................................................................ 105

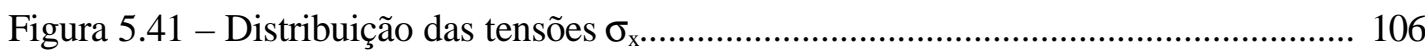

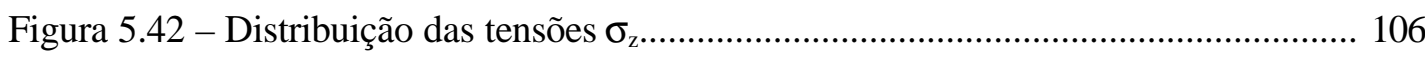

Figura 5.43 - Parede analisada (situação 2)............................................................... 107

figura 5.44 - Malha discretizada (parede sem revestimento)........................................... 107

Figura 5.45 - Gráfico força x deslocamento das paredes sem revestimento (análise teórica $\mathrm{x}$ análise teórica) 107

Figura 5.46 - Parede analisada com revestimento........................................................... 108

figura 5.47 - Malha discretizada (parede revestida)...................................................... 108

Figura 5.48 - Gráficos força $\mathrm{x}$ deslocamento das paredes revestidas (análise experimental $\mathrm{x}$ análise teórica).

Figura 5.49 - Gráfico força $\mathrm{x}$ deslocamento das paredes sem revestimento (análise teórica considerando o $\mathrm{E}_{\text {equivalente }}$ ).

Figura 5.50 - Gráfico força x deslocamento das paredes revestidas com argamassa fraca (análise teórica considerando o $\mathrm{E}_{\text {equivalente) }}$

Figura 5.51 - Gráfico força x deslocamento das paredes revestidas com argamassa forte (análise teórica considerando o $\mathrm{E}_{\text {equivalente }}$ )

Figura 6.1 - Ruptura da parede P01 120

Figura 6.2 - Esquema de ensaio 120

Figura 6.3 - Gráfico força x deslocamento médio das paredes P01 e P02 120

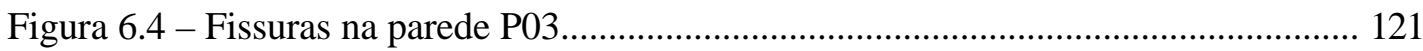

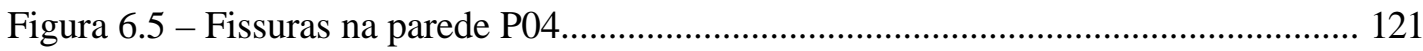

Figura 6.6 - Gráfico força x deslocamento médio da parede P03 e P04............................. 121

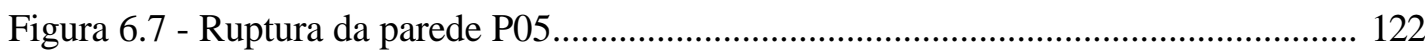

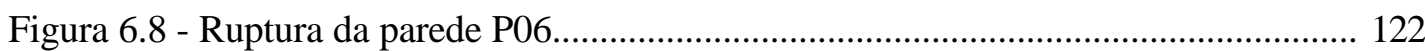

Figura 6.9 - Gráfico força x deslocamento médio das paredes P05 e P06......................... 122

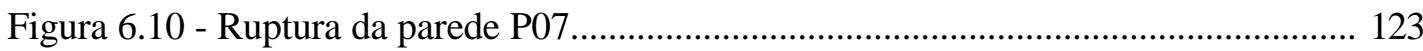

Figura 6.11 - Fissuras da parede P08........................................................................... 123 
Figura 6.12 - Gráfico força x deslocamento médio das paredes P07 e P08........................ 123

Figura 6.13 - Fissuras horizontais na parede P09....................................................... 124

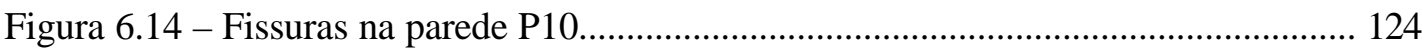

Figura 6.15 - Gráfico força x deslocamento médio das paredes P09 e P10........................ 124

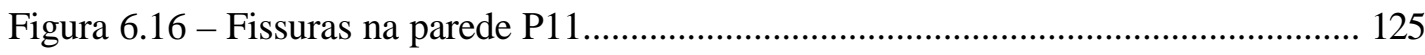

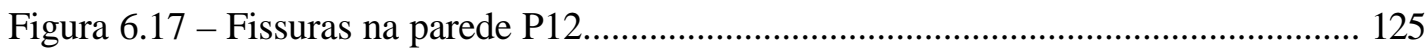

Figura 6.18 - Gráfico força x deslocamento médio das paredes P11 e P12....................... 125

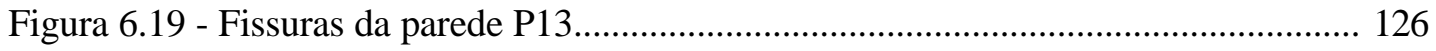

Figura 6.20 - Fissuras da parede P14 ...................................................................... 126

Figura 6.21 - Gráfico força x deslocamento médio das paredes P13 e P14....................... 126

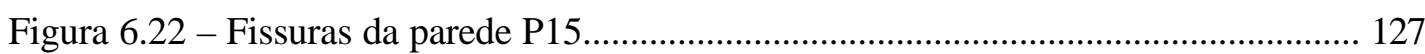

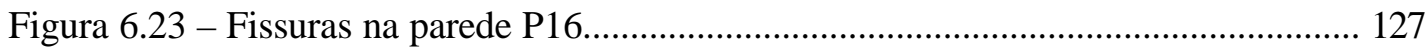

Figura 6.24 - Gráfico força x deslocamento médio das paredes P15 e P16........................ 127

Figura 6.25 - Gráfico força x deslocamento das paredes ensaiadas à compressão diagonal

Figura 6.25 - Gráfico representativo da força de ruptura experimental e teórica das paredes

Figura 6.26 - Deformação das paredes transversais ou resistentes ao cisalhamento 135

Figura 7.1 - Configuração final de fissuras da parede P01 ................................................. 142

Figura 7.2 - Configuração final de fissuras da parede P02 ………………………............ 142

Figura 7.3 - Gráfico força x deslocamento médio das paredes P01 e P02 ........................... 142

Figura 7.4 - Esquema de ensaio da parede P03 …........................................................... 143

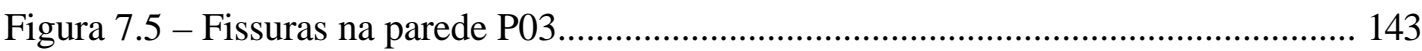

Figura 7.6 - Gráfico força x encurtamento médio da parede P03 ...................................... 143

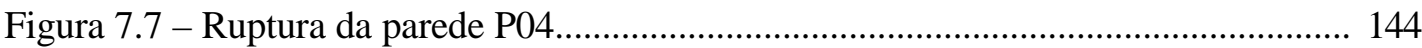

Figura 7.8 - Seccionamento de toda a fiada de blocos na ruptura da parede P04............... 144

Figura 7.9 - Gráfico força x encurtamento médio da parede P04 ..................................... 144

Figura 7.10 - Configuração final de fissuras da parede P05............................................. 145

Figura 7.11 - Gráfico força x encurtamento médio das paredes P05 .................................. 145

Figura 7.12 - Seccionamento de uma das fiadas de bloco da parede P06.......................... 146

Figura 7.13 - Gráfico força x encurtamento médio das paredes P06................................. 146

Figura 7.14 - Gráfico momento fletor x deslocamento das paredes ensaiadas

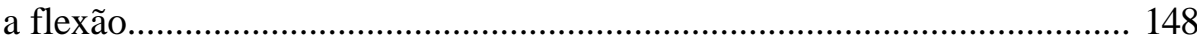

Figura 7.15 - Esquema da parede para cálculo da inércia............................................... 150 
Figura 8.1 - Aspecto em elevação do primeiro protótipo idealizado.................................... 156

Figura 8.2 - Aspecto em elevação do protótipo ensaiado.................................................... 156

Figura 8.3 - Ilustração dos componentes de uma verga................................................... 157

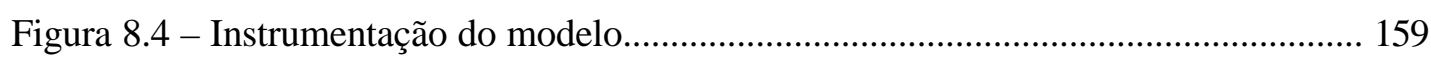

Figura 8.5 - Vista de cima dos do protótipo instrumentado............................................... 159

Figura 8.6 - Aspecto geral da parede P01 (sem revestimento)........................................... 161

Figura 8.7 - Configuração de fissuras da parede P01...................................................... 161

Figura 8.8 - Gráfico força x deslocamento da parede P01 - transdutores

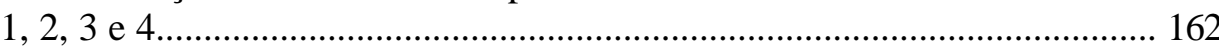

Figura 8.9 - Gráfico força x deslocamento da parede P01 - transdutor 6......................... 162

Figura 8.10 - Ruptura da parede P02 (revestida)............................................................. 163

Figura 8.11 - Configuração das fissuras........................................................................ 163

Figura 8.12 - Gráfico força x deslocamento da parede P02 - transdutores

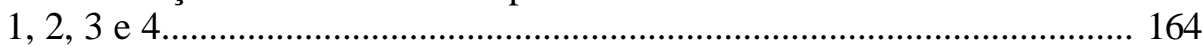

Figura 8.13 - Gráfico força x deslocamento da parede P02 - transdutor 6........................ 164

Figura 8.14 - Esquema de ensaio da parede P03 ........................................................... 165

Figura 8.15 - Configuração de fissuras da parede sem revestimento................................. 165

Figura 8.16 - Gráfico força x deslocamento da parede P03 - transdutores

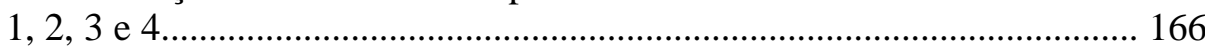

Figura 8.17 - Gráfico força x deslocamento da parede P03 - transdutor 6........................ 166

Figura 8.18 - Configuração de fissuras da parede reabilitada - face A............................... 167

Figura 8.19 - Configuração de fissuras da parede P1r - face B......................................... 167

Figura 8.20 - Gráfico força x deslocamento da parede P01r - transdutores

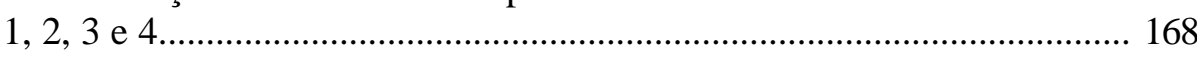

Figura 8.21 - Gráfico força x deslocamento da parede P01r - transdutor 6....................... 168

Figura 8.22 - Gráfico força $\mathrm{x}$ deslocamento das protótipos ensaiados -

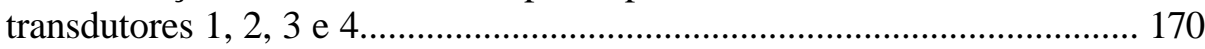

Figura 8.23 - Gráfico força x deslocamento das protótipos ensaiados - transdutor 6......... 171

Figura 8.24 - Protótipo analisado - ilustração da malha de discretização........................... 173

Figura 8.25 - Ilustração da malha deformada após aplicado o carregamento $(155 \mathrm{kN})$.

Figura 8.26 - Distribuição das tensões $\sigma_{\mathrm{x}}\left(\mathrm{kN} / \mathrm{cm}^{2}\right)$ - protótipo sem revestimento.............. 174

Figura 8.27 - Distribuição das tensões $\sigma_{\mathrm{y}}\left(\mathrm{kN} / \mathrm{cm}^{2}\right)$ - protótipo sem revestimento.............. 174

Figura 8.28 - Distribuição das tensões $\tau_{\mathrm{xy}}\left(\mathrm{kN} / \mathrm{cm}^{2}\right)$ - protótipo sem revestimento.............. 175

Figura 8.29 - Distribuição das tensões $\sigma_{1}\left(\mathrm{kN} / \mathrm{cm}^{2}\right)$ - protótipo sem revestimento.............. 175

Figura 8.30 - Distribuição das tensões $\sigma_{2}\left(\mathrm{kN} / \mathrm{cm}^{2}\right)$ - protótipo sem revestimento.............. 176

Figura 8.31 - Distribuição das tensões $\sigma_{\mathrm{x}}\left(\mathrm{kN} / \mathrm{cm}^{2}\right)$ - protótipo com revestimento............. 176 
Figura 8.32 - Distribuição das tensões $\sigma_{\mathrm{y}}\left(\mathrm{kN} / \mathrm{cm}^{2}\right)$ - protótipo com revestimento............ 177

Figura 8.33 - Distribuição das tensões $\tau_{\mathrm{xy}}\left(\mathrm{kN} / \mathrm{cm}^{2}\right)$ - protótipo com revestimento............ 177

Figura 8.34 - Distribuição das tensões $\sigma_{1}\left(\mathrm{kN} / \mathrm{cm}^{2}\right)$ - protótipo com revestimento.............. 178

Figura 8.35 - Distribuição das tensões $\sigma_{2}\left(\mathrm{kN} / \mathrm{cm}^{2}\right)$ - protótipo com revestimento.............. 178

Figura 8.36 - Gráfico força x deslocamento das paredes sem revestimento na análise experimental e teórica (transdutores 1, 2, 3 e 4)......................................... 181

Figura 8.37 - Gráfico força $\mathrm{x}$ deslocamento das paredes revestidas na análise experimental e teórica (transdutores 1, 2, 3 e 4) ...................................... 182

Figura 8.38 - Gráfico força x deslocamento das paredes sem revestimento na análise experimental e teórica (transdutor 6)...................................................... 182

Figura 8.39 - Gráfico força $\mathrm{x}$ deslocamento das paredes revestidas na análise experimental e teórica (transdutor 6)......................................................... 183 


\section{LISTA DE TABELAS}

Tabela 3.1 - Revestimentos de argamassa armada.................................................. 23

Tabela 3.2 - Descrição dos corpos-de-prova ensaiados................................................... 26

Tabela 3.3 - Resultados dos ensaios (SINGH et al.,1988)............................................. 27

Tabela 3.4 - Resultados obtidos nos ensaios de pequenas paredes.................................... 29

Tabela 4.1 - Resumo dos resultados dos ensaios.......................................................... 48

Tabela 5.1 - Resultados dos ensaios das paredinhas ensaiadas à compressão axial.......... 89

Tabela 5.2 - Propriedades dos materiais......................................................................... 104

Tabela 5.3 - Valores dos módulos de elasticidade considerado nos modelos teóricos....... 110

Tabela 5.4 - Encurtamentos obtidos nos modelos teóricos analisados................................ 111

Tabela 6.1 - Resultados dos ensaios das paredes ensaiadas à compressão diagonal........... 128

Tabela 6.2 - Valores da carga de ruptura experimental e da carga máxima teórica............ 132

Tabela 6.3 - Resistências ao cisalhamento recomendadas pela BS 5628/1978................... 134

Tabela 6.4 - Resistências ao cisalhamento recomendadas pela NCH 1928/1954................ 134

Tabela 6.5 - Resistências ao cisalhamento recomendadas por SAHLIN (1971)................. 135

Tabela 6.6 - Resultados obtidos através da ASTM E 519/93 ............................................ 136

Tabela 7.1 - Resultados dos ensaios das paredes à flexão................................................ 147

Tabela 7.2 - Valores obtidos nas análises teórica e experimental.................................... 152

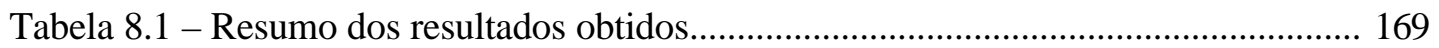

Tabela 8.2 - Principais eventos e valores da força aplicada e de tensões............................ 179 


\section{RESUMO}

OLIVEIRA, F. L. (2001). Reabilitação de paredes de alvenaria pela aplicação de revestimentos resistentes de argamassa armada. São Carlos,2001. 203p. Tese (Doutorado) - Escola de Engenharia de São Carlos, Universidade de São Paulo.

O presente trabalho apresenta os resultados obtidos na pesquisa sobre o uso de revestimentos resistentes de argamassas de cimento e areia na reabilitação de paredes de alvenaria, quando solicitadas à compressão axial, compressão diagonal e flexão de painéis. Os ensaios foram baseados nas normas NBR 8949, ASTM 519 e NBR 14322 respectivamente. $\mathrm{O}$ objetivo dos ensaios realizados foi observar o comportamento estrutural de paredes de blocos de concreto revestidas com diversos tipos de argamassa de cimento e areia, os quais resultaram de combinações de argamassa de resistência baixa ou mais elevada, telas de aço soldadas, fibras de aço, fibras de polipropileno e conectores de cisalhamento. Os modelos dos ensaios de compressão axial tinham dimensões de 39 x $81 \mathrm{~cm}$ e foram confeccionados em gabaritos de aço para uma maior precisão durante o assentamento. Para os ensaios de compressão diagonal foram idealizados gabaritos de madeira para confecção e transporte dos modelos cujas dimensões eram de 80 x $80 \mathrm{~cm}$. Nos ensaios de flexão as paredes $(80 \times 1,60)$ foram ensaiadas com a face maior na posição horizontal com duas situações de carregamento. Depois de terminados estes ensaios e analisados os resultados foi realizada também uma série de ensaios sobre painéis de alvenaria, submetidos a forças distribuídas numa região pequena do topo da parede e ensaiados em três situações diferentes: paredes íntegras, reabilitadas e reforçadas. A decisão de ensaiar painéis com aberturas se deu pela intenção de criar situações de desvio de tensões no plano da parede, provocando esforços de compressão, tração e cisalhamento. Todos os ensaios foram realizados com uso de equipamento hidráulico servo-controlado INSTRON, controlando-se a velocidade de deslocamento, o que permitiu observar o comportamento das paredes após à sua resistência de pico. Pode-se dizer que a técnica em estudo apresenta diversos aspectos interessantes, que podem ser explorados tanto na reabilitação (reforço ou reparo) de estruturas de alvenaria, como na execução de estruturas novas com exigências especiais de desempenho.

Palavras-chave: reabilitação, reforço, alvenaria, argamassa armada. 


\begin{abstract}
OLIVEIRA, F. L. (2001). Rehabilitation of masonry walls by the application of resistant ferrocement overlays. Sao Carlos,2001. 203p. Thesis (PhD) - School of Engineering at São Carlos, University of Sao Paulo.

This paper reports on the results of a study about the use of resistant overlays of cement and sands mortars in the rehabilitation of masonry walls subjected to axial and diagonal compression and flexure. The tests were carried out according to the NBR8949, ASTM 519 and NBR 14322 codes. The purpose of the tests was to observe the structural behavior of concrete block walls covered with several combinations of materials: plain mortar with two different strengths, welded steel mesh, steel fibers, polypropylene fibers and shear connectors. The dimensions of the specimens subjected to axial compression tests were $390 \times 810 \mathrm{~mm}$. They were built inside steel templates for a better precision during their construction. Wooden templates were set up for the diagonal compression tests to build and transport the $800 \times 800 \mathrm{~mm}$ specimens. In the flexure tests, the walls $(800 \times 1600 \mathrm{~mm})$ were tested with the larger side in the horizontal position, using two loading situations. After the conclusion of these tests and an analysis of the results, a series of tests was carried out on masonry panels subjected to loads distributed over a small area at the top of the wall. Three different situations were tested, i.e., undamaged walls, rehabilitated walls and reinforced walls. The decision to test panels with openings was based on the idea of creating situations to deviate the stresses in the plane of the wall, thereby inducing compression, tension and shear. All the tests were performed using an universal servo-controlled INSTRON machine to control the displacement speed, allowing the observation of the behavior of the walls after their peak resistance. Based on this study, it can be stated that this technique offers several interesting aspects that may be applied both in the rehabilitation (strengthening or repair) of masonry structures and in the construction of new structures with special performance requirements.
\end{abstract}

Keywords: rehabilitation, strengthening, masonry, ferrocement. 


\section{INTRODUÇÃO}

Desde a Antigüidade a alvenaria vem sendo largamente utilizada como forma de construção em habitações, monumentos e templos religiosos. Exemplos famosos deste tipo de técnica construtiva são a Pirâmide de Queóps e o Farol de Alexandria.

Admite-se que as primeiras construções em alvenaria datam do ano 10.000 A.C., quando assírios e persas construíam com tijolos queimados ao sol. Já em 3.000 A.C., estes mesmos povos utilizavam os tijolos queimados em fornos. Nos séculos XII a XVII, as grandes catedrais, que se conservam até os dias de hoje, são exemplos de alvenaria como estrutura-suporte de edifícios de grande altura. Como exemplos do século XIX, sobrados e casarões foram construídos e são atualmente característica presente da época colonial no Brasil.

Todavia, as construções em alvenaria eram dimensionadas empiricamente e a concepção estrutural era intuitiva, daí o motivo de encontrarmos nestas antigas construções paredes com espessuras que variam de $30 \mathrm{~cm}$ a $1,30 \mathrm{~m}$.

Com o aparecimento do concreto armado e do aço estrutural no início do século, a alvenaria se restringiu às construções de pequeno porte, reaparecendo, após inúmeras pesquisas, no início da década de 50, quando o engenheiro suíço Paul Haller dimensionou e construiu na Basiléia em 1951, um edifício de 13 andares, em alvenaria não armada, com paredes resistentes internas de $15 \mathrm{~cm}$ de espessura e externas de $37,5 \mathrm{~cm}$.

Em países como a Inglaterra, França, Estados Unidos, Canadá e Austrália, a utilização da alvenaria estrutural está amplamente difundida, existindo há muito tempo um conjunto de normas técnicas sobre o cálculo e procedimentos construtivos.

No Brasil, pode-se dizer que já houve grandes avanços na área de Alvenaria Estrutural, embora a normalização tenha sido realizada somente em meados de 1980. 
Alguns exemplos de grandes construções em alvenaria são o Central Parque Lapa (1972), em São Paulo, com 4 blocos de 12 pavimentos; o Jardim Prudência (1977), em São Paulo, com 9 pavimentos e o Conjunto Habitacional de Itaquera (1978), também em São Paulo. Neste último exemplo, foram utilizados simultaneamente vários processos construtivos com o objetivo de comparar custos e prazos de execução, chegando-se ao resultado de que a alvenaria estrutural foi o processo que se adequou melhor às premissas básicas.

Atualmente, verifica-se uma tendência de aumento do volume de construção de edifícios em alvenaria estrutural. Isto se deve ao melhor discernimento das vantagens e desvantagens - hoje conhecidas com maior clareza devido às intensas pesquisas realizadas nesta área - do processo construtivo, que pode contar com diversos parâmetros racionais de análise e decisão na fase de projeto e de execução da obra.

O sucesso econômico da alvenaria estrutural tem sido alcançado não só pela racionalização da estrutura em si, mas também porque é possível que as paredes que constituem a estrutura da edificação desempenhem várias outras funções simultaneamente, tais como subdivisão de espaço, isolamento térmico e acústico, proteção ao fogo e adequação às condições climáticas.

Conclui-se então que as alvenarias foram evoluindo e deixaram de ser pesadas, espessas e rígidas como na Antigüidade. Tornaram-se delgadas e os processos de produção, mais industrializados. Contudo, ao lado da evolução das técnicas de projeto e de execução de obras, surgiram problemas de falhas nas construções. Assim, o diagnóstico das causas e dos mecanismos de evolução dessas falhas, as formas de manifestação e as medidas de prevenção e de recuperação vêm sendo estudados por pesquisadores de todo o mundo, de forma a acrescentar técnicas adequadas para execução de reparos ou reforços nas estruturas.

Diante da necessidade permanente de racionalização e melhoria da confiabilidade na definição de estratégias de reabilitação e no projeto tecnológico (conjugando a análise estrutural com os procedimentos de seleção de materiais, processos de execução, etc.) no campo das construções de alvenaria estrutural, este trabalho de pesquisa objetiva dar início ao estudo de paredes de alvenaria reabilitadas 
mediante adição de revestimentos resistentes de argamassa ou microconcreto armado, analisando as seguintes variáveis:

a) Avaliação da eficiência das técnicas de reabilitação indicadas na literatura;

b) Estudo da distribuição de tensões normais e tangenciais que surgem nas paredes íntegras ou danificadas, submetidas a diversos tipos de solicitação;

c) Investigação experimental e analítica do comportamento composto ou parcialmente composto do conjunto formado pelas camadas de revestimento de argamassa armada e núcleo de alvenaria;

d) Estudo das possibilidades de aplicação dessa técnica na reabilitação de estruturas de alvenaria.

Portanto, o presente trabalho objetiva não só contribuir à solução de falhas nas alvenarias, mas também formalizar procedimentos aplicáveis à resolução e prevenção de problemas estruturais. Os resultados deste trabalho também poderão ser estendidos ao projeto e à execução de paredes de alvenaria com características especiais de desempenho, que possam ser supridas pela adição de revestimentos resistentes, como no caso de paredes de reservatórios, muros de arrimo, etc., que sejam resistentes a ações de carregamentos perpendiculares ao plano da parede.

As atividades desenvolvidas e a metodologia realizada na pesquisa estão descritas de maneira sucinta a seguir:

a) Pesquisa bibliográfica onde foram analisados inicialmente os casos mais simples de recuperação ou reforço de paredes planas, com ou sem aberturas, submetidas a diversos tipos de solicitação. Ressalta-se que algumas áreas correlatas também foram estudadas para maior exploração do assunto pesquisado;

b) Análise teórica efetuada com auxílio do programa computacional disponível (ANSYS) fundamentado no Método dos Elementos Finitos, por meio de análises simplificadas, ressaltando-se que este trabalho de pesquisa enfatiza a obtenção de dados experimentais;

c) Os ensaios realizados tiveram valor principalmente qualitativo, podendo-se eventualmente chegar à validação de técnicas para uso prático. Todavia, não se 
teve a pretensão de elaborar modelos matemáticos mais requintados e calibrá-los por meio de dados experimentais;

d) Os fenômenos ocorridos durante os ensaios foram estudados, bem como todos os resultados de cálculos numéricos analisados, e avaliou-se potencial que a técnica de reabilitação em estudo pode proporcionar à estrutura danificada, a recuperação ou a melhoria de suas características originais quando submetida a solicitações de flexão, compressão e cisalhamento;

e) A metodologia dos ensaios foi definida de acordo com as normas existentes, sendo que os procedimentos, quando necessário, sofreram algumas modificações. Os ensaios realizados estão representados nas Figuras 1.1, 1.2 e 1.3. Além disso, foram também realizados ensaios em protótipos com abertura de dimensões de 1,99 x $1,60 \mathrm{~m}$;

f) Alguns ensaios-piloto foram realizados para avaliação preliminar da técnica proposta, assim como para verificar a metodologia de ensaio;

g) Durante o desenvolvimento da pesquisa e o estabelecimento de conclusões parciais, foram efetuadas avaliações dos resultados efetivamente alcançados.

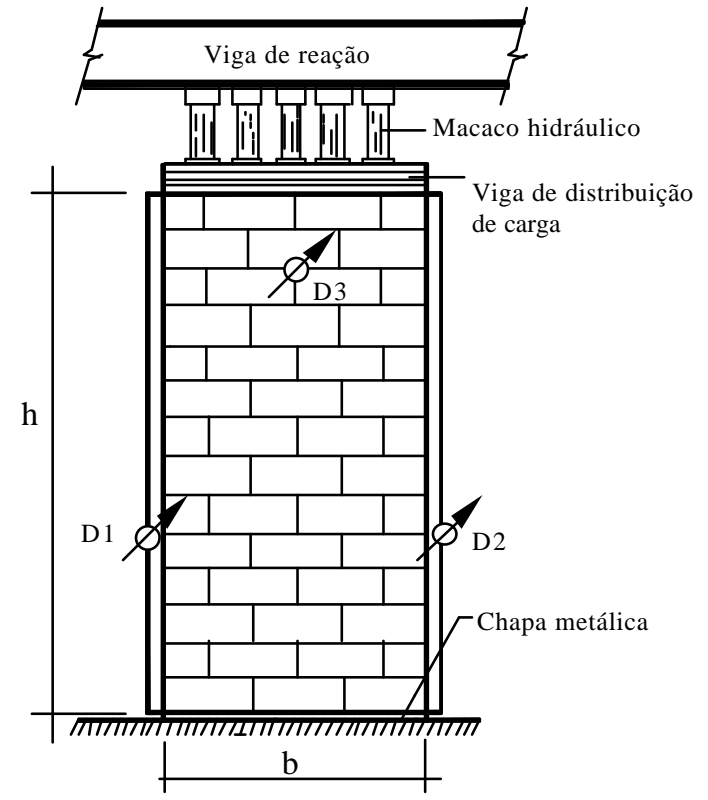

Figura 1.1 - Ensaio de compressão axial.

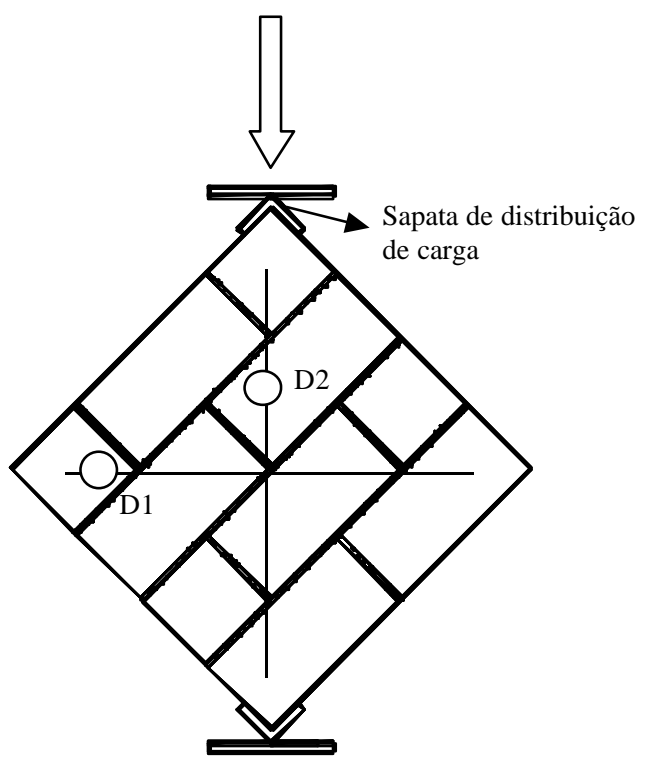

Figura 1.2 - Ensaio de compressão diagonal. 


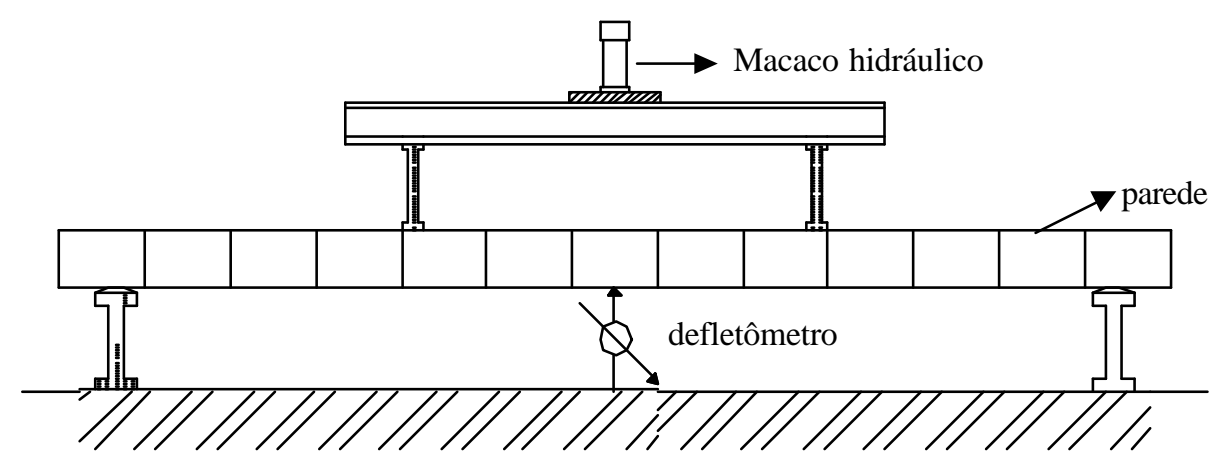

Figura 1.3 - Ensaio de flexão.

Dentro desse contexto, o corpo deste trabalho está dividido da seguinte forma:

No Capítulo 2 são abordadas as patologias mais freqüentes nas alvenarias estruturais e de vedação, como também, os métodos de reabilitação empregados para sua recuperação. No Capítulo 3 aborda-se o conhecimento disponível sobre o uso dos revestimentos resistentes para reforço e reparo de componentes (pilares, vigas, lajes, reservatórios, etc.) e estruturas de alvenaria com diferentes tipos de revestimentos e sob diferentes solicitações. São apresentados os resultados e as conclusões, bem como comentários sucintos sobre cada referência bibliográfica.

No Capítulo 4 do trabalho são abordadas de maneira geral as análises teóricas e experimentais realizadas sobre séries de modelos submetidos à compressão axial, compressão diagonal e flexão. São relatadas as técnicas construtivas utilizadas na execução dos modelos, os equipamentos e dispositivos empregados nos ensaios, a instrumentação de cada modelo justificando-se a sua posição, a metodologia de cada ensaio e as normas técnicas consultadas.

Nos Capítulos 5, 6, 7 e 8 são abordadas de maneira individual cada uma das séries de ensaios, descrevendo-se os resultados obtidos e a sua análise dos mesmos. O mecanismo de ruptura, a resistência final e os deslocamentos encontrados são apresentados em forma de figuras, tabelas e gráficos. Faz-se também comentários sobre algumas dificuldades encontradas na metodologia empregada nos ensaios e modificações são sugeridas.

$\mathrm{Na}$ descrição das "análises teóricas" são relatados os métodos analíticos e numéricos empregados, bem como comentários sobre o programa ANSYS utilizado, e são feitas as considerações sobre a modelagem numérica do modelo, como o elemento escolhido, as características dos materiais e a vinculação. São analisadas as 
tensões, as deformações e o deslocamentos obtidos comparando-os com os dados experimentais. Serão analisadas três situações diferentes de paredes submetidas às mesmas solicitações utilizadas na análise experimental. A primeira refere-se á parede sem revestimento, a segunda com módulo de elasticidade do núcleo (parede) menor que o do revestimento $-\mathrm{E}_{\mathrm{pa}}<\mathrm{E}_{\mathrm{rev}}-\mathrm{e}$ a terceira com módulo de elasticidade do núcleo maior que o do revestimento - $\mathrm{E}_{\mathrm{pa}}>\mathrm{E}_{\mathrm{rev}}$.

Os resultados da análise experimental e teórica são discutidos e apresentados através de gráficos e tabelas. Os principais fenômenos e parâmetros analisados nos ensaios serão a resistência, a fissuração, ductilidade, a forma de ruína e o comportamento pós-pico.

As conclusões apresentadas no Capítulo 09 são fundamentadas na revisão bibliográfica e nos resultados da análise experimental e numérica. Analisa-se a validade da técnica proposta, o desenvolvimento da pesquisa e a confrontação entre os objetivos propostos e atingidos dentro da limitação do trabalho. Propõe-se temas para continuidade da pesquisa. 


\section{PATOLOGIA NAS ALVENARIAS E SUA REABILITAÇÃo}

Os problemas patológicos e a necessidade de reabilitação afetam as construções desde os primórdios das civilizações e dependem principalmente da qualidade da edificação construída. Como nos últimos tempos tem-se observado uma grande preocupação em relação aos aspectos relacionados com a durabilidade e manutenção das obras civis, pode-se notar um sensível desenvolvimento de tecnologias destinadas a solucionar problemas em peças deterioradas, danificadas ou tornadas obsoletas.

Cresce a área da Engenharia denominada de Patologia e Terapia das Construções, que trata justamente das correções de problemas patológicos, indicando os fatores que os provocaram e os procedimentos e técnicas mais adequadas para superá-los.

Apesar deste ramo da Engenharia estar se desenvolvendo com relativa rapidez, os profissionais ainda contam apenas com técnicas baseadas na experiência empírica acumulada. Isto ocorre porque os processos de reabilitação apresentam, em sua maioria, um caráter artesanal e particular, pois cada problema enfrentado tem características próprias.

Não há dados precisos sobre o volume de aplicações e o estado das construções de alvenaria no Brasil, mas possivelmente, dada a longa tradição de uso, uma análise patológica revelaria um quadro muito extenso de situações de deterioração. Muitos dos problemas de desempenho das construções poderiam ser evitados com materiais, técnicas, procedimentos e normas adequadas.

A recuperação de construções de alvenaria vem sendo estudada de modo mais sistemático desde a década de 60, quando algumas publicações passaram a 
demonstrar a fenomenologia e o que deve ser feito para evitar e tratar de problemas patológicos como trincas e fissuras, como por exemplo C.S.T.C. (1967) e PFEFFERMANN (1968).

As paredes de alvenaria apresentam em geral bom comportamento frente às solicitações de compressão, não ocorrendo o mesmo em relação às solicitações de tração, flexão e cisalhamento. Nos casos de fissuração, as tensões de tração e de cisalhamento são responsáveis pela quase sua totalidade. Como as alvenarias são muito susceptíveis às distorções e deformações excessivas, elas exigem cuidados especiais no projeto das fundações, assim como na execução e no cálculo da estrutura portante.

No presente trabalho será dada ênfase às patologias referentes à trincas e fissuras. Elas serão subdivididas em dois tipos: patologias nas alvenarias de vedação e patologias nas alvenarias estruturais. Ressalta-se que em algumas situações a mesma ocorrência patológica pode ocorrer nos dois tipos de alvenaria, mas são citadas separadamente para melhor entendimento do texto.

\subsection{Patologia nas alvenarias de vedação}

O aparecimento de trincas nas paredes de alvenaria indica um estado de deformação excessiva dos elementos estruturais e comprometimento da durabilidade e/ou estanqueidade à água do edifício, trazendo descontentamento (eventualmente pânico) ao usuário pela possibilidade de ruína dos elementos fissurados. É preciso certificar-se das causas e possíveis danos que as trincas podem trazer à edificação, para definir se podem comprometer a segurança estrutural e a estanqueidade, ou se elas são somente de caráter estético, que mesmo assim devem ser corrigidas para evitar eventual surgimento de outras patologias.

THOMAZ (1998) destaca também a evolução da tecnologia do concreto armado, representada pela fabricação de aços com grande limite de elasticidade, produção de cimentos de melhor qualidade e desenvolvimento de métodos mais refinados de cálculo. As estruturas de concreto foram se tornando cada vez mais flexíveis, o que exige a análise mais cuidadosa das suas deformações e de suas respectivas conseqüências.

Não se têm observado comumente problemas graves decorrentes de deformações promovidas por solicitações de compressão (pilares), cisalhamento ou torção. 
Entretanto; a ocorrência de flechas em componentes fletidos tem causado repetidos e graves transtornos aos edifícios, verificando-se, em função das flechas desenvolvidas em componentes estruturais, freqüentes problemas de compressão de caixilhos, empoçamento de água em lajes de cobertura, destacamento de pisos cerâmicos e ocorrência de fissuras em paredes.

Deve-se frisar que o desenvolvimento das fissuras será função não só da grandeza da flecha, mas também de diversas características da alvenaria como: dimensões dos blocos, tipo de junta, características do material de assentamento, dimensões e localização dos vãos inseridos na parede, etc.. Contudo, na previsão da flecha de um componente fletido é essencial considerar as parcelas das flechas instantâneas (antes e após fissuração) e flechas provenientes da deformação lenta do concreto. Quando as alvenarias não são dimensionadas para suportar as flechas excessivas das estruturas de concreto, estas tendem a introduzir esforços de tração e cisalhamento causando trincas em diversas configurações.

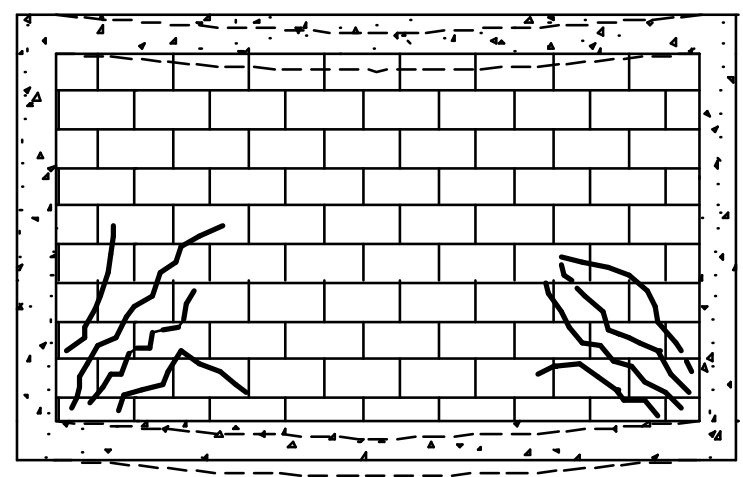

Figura 2.1 - Flecha da viga superior igual à da viga inferior porém maior que a alvenaria suporta - adaptada de PFEFFERMANN (1968).

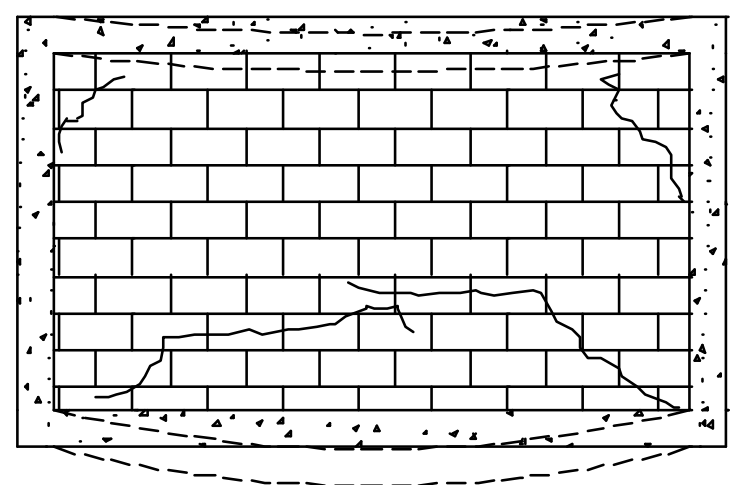

Figura 2.2 - Flecha da viga inferior é maior que a da viga superior - adaptada de PFEFFERMANN (1968). 


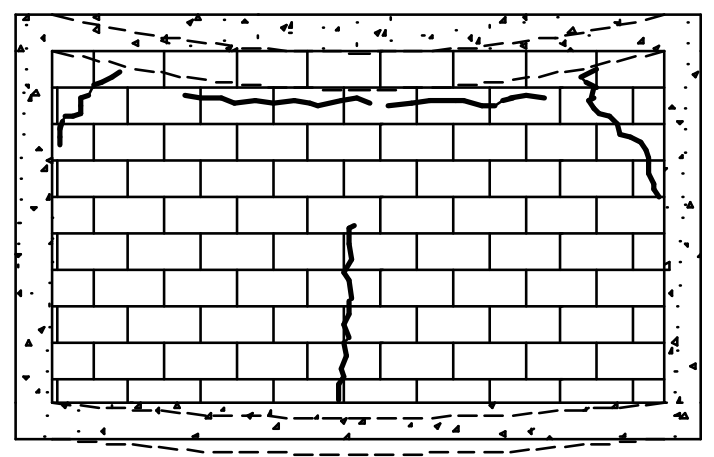

Figura 2.3 - Flecha da viga inferior é menor que a da viga superior - adaptada de PFEFFERMANN (1968).

Ocorrem também destacamentos entre alvenarias e estrutura pela retração de secagem dos blocos mal curados e do abatimento plástico da argamassa de assentamento, quando solicitada pelo peso próprio da parede recém construída e sua posterior retração de secagem. Isto acontece quando a parede é precocemente encunhada na estrutura, ocorrendo também destacamentos no encontro da parede com a viga ou laje junto ao topo.

A retração das alvenarias de vedação pode também dar origem a fissuras verticais, igualmente espaçadas no corpo das paredes mais longas; nos encontros entre paredes, nas seções onde eventualmente ocorra mudança de espessura da parede, ou ainda, nas seções enfraquecidas pela presença de aberturas ou tubulações embutidas.

THOMAZ (1989) comenta que diversos fatores influenciam o comportamento mecânico das paredes de alvenaria como: geometria, rugosidade superficial e porosidade do componente de alvenaria; índice de retração, poder de aderência e poder de retenção de água da argamassa de assentamento; esbeltez, eventual presença de armaduras, número e disposição das paredes contraventantes; amarrações, cintamentos, disposição e tamanho dos vãos de portas e janelas e enfraquecimentos provocados pelo embutimento de tubulações, rigidez dos elementos de fundação, geometria do edifício, etc..

Um fator também significante no aparecimento de fissuras é a heterogeneidade resultante da utilização conjunta de materiais diferentes com propriedades distintas. Ou seja, blocos e argamassa de assentamento possuem resistência mecânica, módulo 
de deformação longitudinal, coeficiente de Poisson e outros parâmetros diferentes e, em função dessa não coincidência de propriedades mecânicas e elásticas, as fissuras podem propagar-se tanto pelas juntas como seccionar os componentes de alvenaria. Hedstrom et al. apud SABBATINI (1984), por exemplo, determinaram a distribuição de tensões na face dos blocos, após ruptura da junta vertical, e comprovaram ocorrer uma concentração de tensões no centro do bloco, no ponto correspondente à junta vertical falida. Nessa ocasião três situações podem ocorrer:

a) se argamassa for mais resistente que o bloco, a resistência de aderência ao cisalhamento da junta horizontal for adequada e, se as tensões concentradas na região central dos blocos contíguos à junta falida excederem a resistência à tração dos blocos, estes serão seccionados no meio, bem como a argamassa entre as duas fiadas, (Figura 2.4);

b) Se a argamassa for menos resistente que o bloco, mas apresentar um alto módulo de elasticidade e/ou a interface apresentar uma fraca resistência de aderência (no cisalhamento), as tensões tangenciais irão atuar na interface seccionando-a até a próxima junta vertical falida, ficando então o desenvolvimento da fissura com o aspecto de uma escada (Figura 2.5);

c) Se a argamassa for menos resistente que o bloco, possuir um baixo módulo de elasticidade e uma capacidade de aderência adequada, as tensões de tração fissurarão a argamassa sob a forma de fissuras distribuídas por toda a massa da junta horizontal (Figura 2.6).

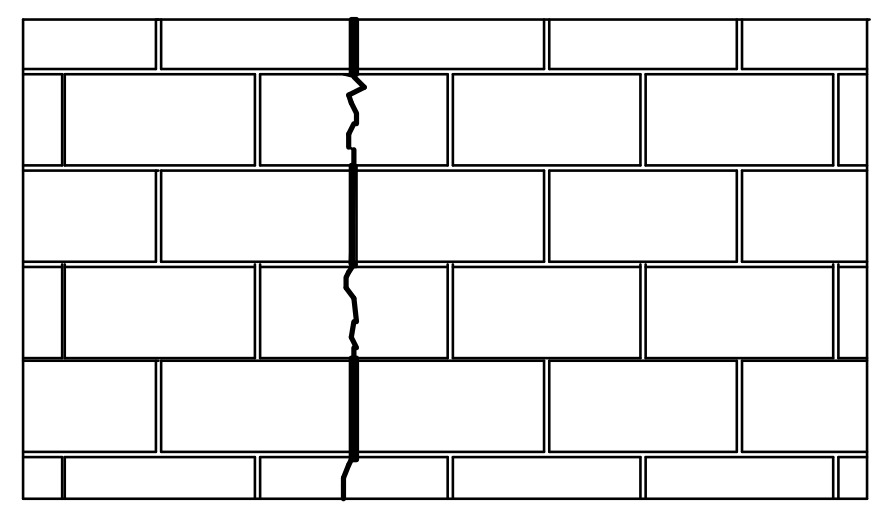

Figura 2.4 - Ruptura seccionando os componentes de alvenaria. Argamassa mais resistente que o bloco e aderência adequada . 


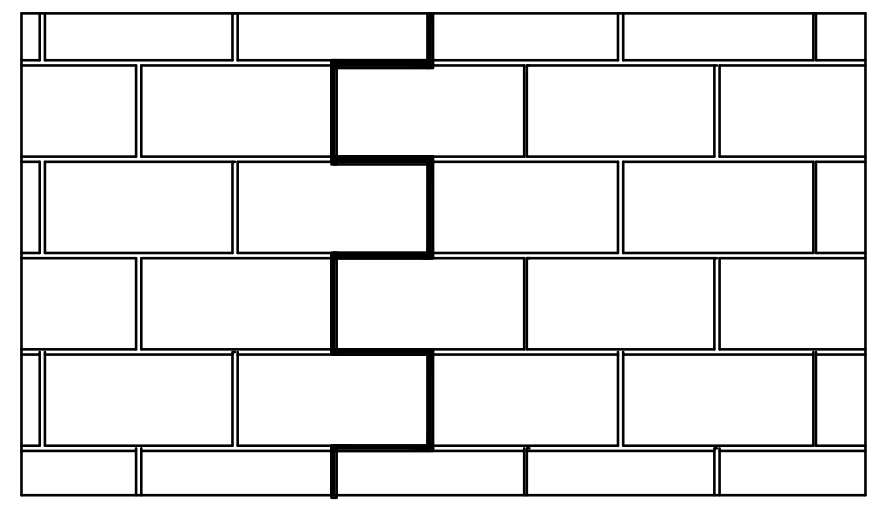

Figura 2.5 - Ruptura em forma de escada. Argamassa menos resistente que o bloco, com módulo de elasticidade elevado e/ou má aderência ao bloco.

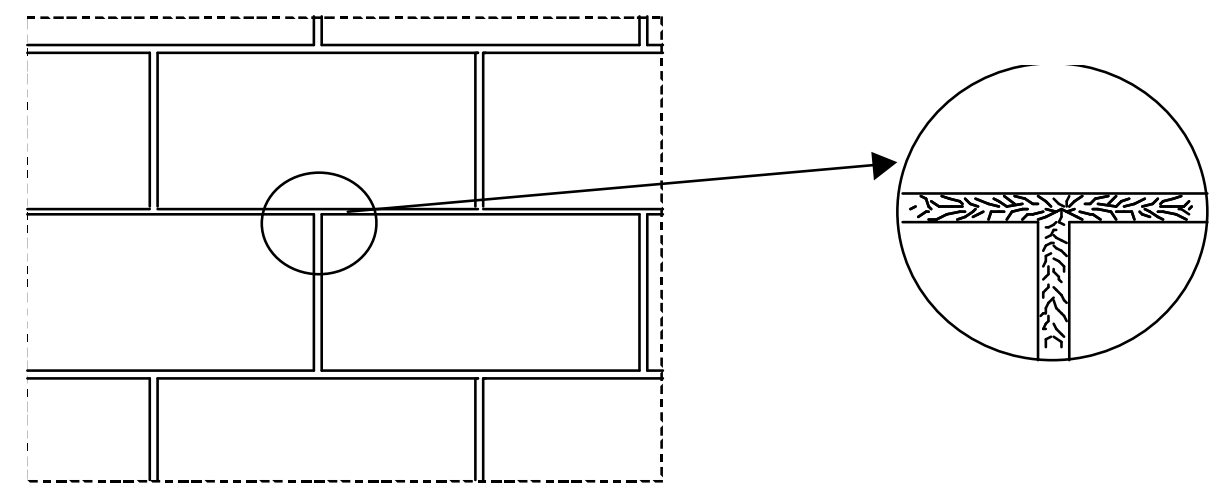

Figura 2.6 - Argamassa menos resistente que o bloco, com baixo módulo de elasticidade e aderência adequada.

\subsection{Patologia nas alvenarias estruturais}

Geralmente, as fissuras que se manifestam em alvenarias oriundas de sobrecarregamentos (cargas axiais uniformemente distribuídas), são verticais, provenientes da deformação transversal da argamassa de assentamento e dos próprios componentes de alvenaria por flexão local.

As fissuras causadas pela atuação de sobrecargas ocorrem pela solicitação excessiva do painel de alvenaria (compressão ou tração), condicionada normalmente pela concentração de esforços em determinadas regiões e à inexistência de dispositivos adequados para distribuí-los. Nas paredes com aberturas de portas ou janelas com ausência ou inadequação de vergas e contravergas, haverá considerável concentração de tensões no entorno dos vãos. As fissuras assumem configurações inclinadas a partir dos cantos dessas aberturas (Figura 2.8). 


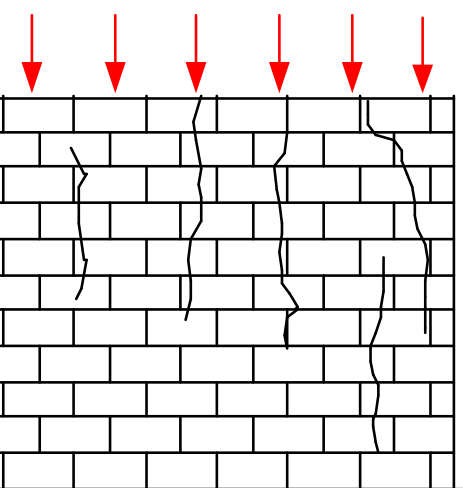

Figura 2.7 - Fissuração oriunda de sobrecarregamentos - adaptada de THOMAZ, 1990.

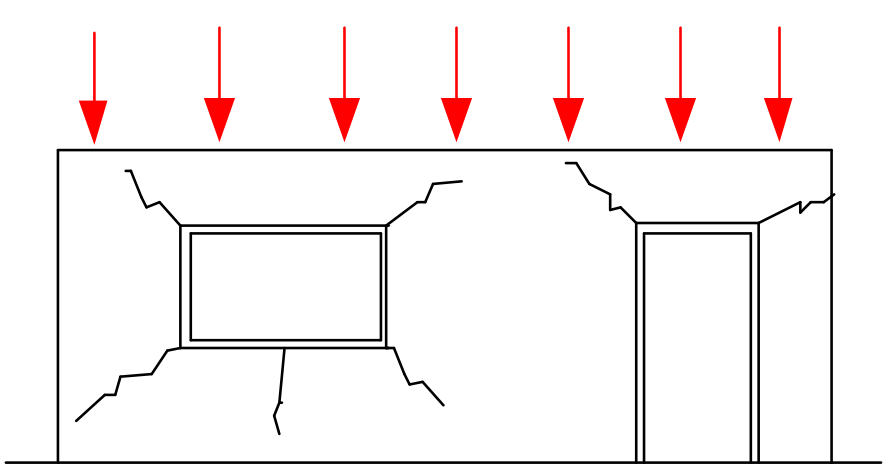

Figura 2.8 - Fissuração em paredes com aberturas - adaptada de THOMAZ, 1990.

As fissuras horizontais nas alvenarias não são tão freqüentes, salvo quando submetidas à flexo-compressão (Figura 2.9). Um caso freqüente desse tipo de fissuras ocorre quando há excessiva deformação de lajes ancoradas nas paredes introduzindo nas mesmas esforços de flexão lateral. Em caso de pouco carregamento elas (as fissuras horizontais) também podem ocorrer devido à expansão das alvenarias por higroscopicidade. A expansão diferenciada entre fiadas de blocos provocam fissuras na base das paredes (Figura 2.10).

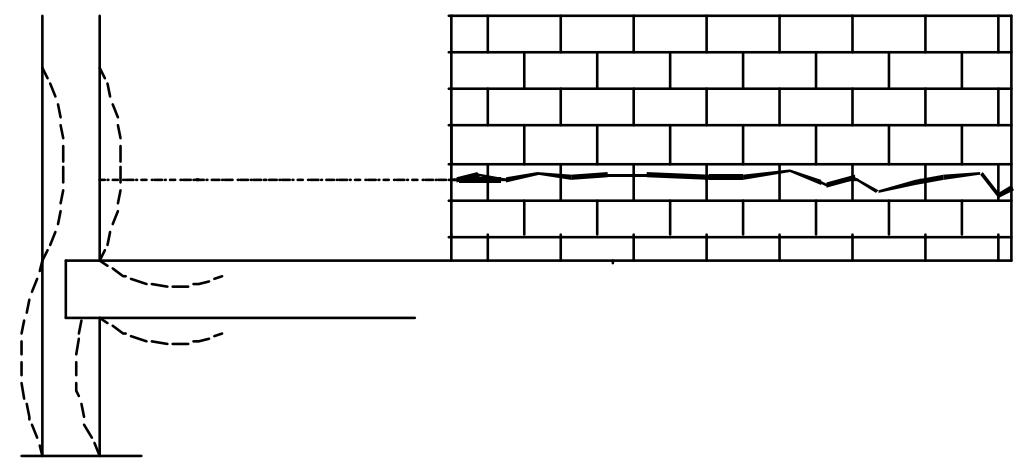

Figura 2.9 - Fissura horizontal na base da alvenaria causada por flexo-compressão - adaptada de THOMAZ, 1990. 


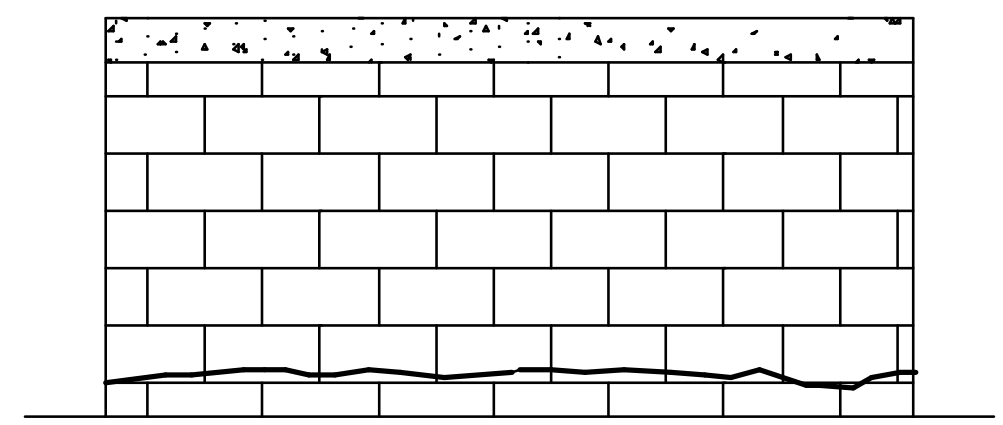

Figura 2.10 - Fissura horizontal na base da alvenaria causada por movimentações higroscópicas - adaptada de THOMAZ, 1990.

As fissuras causadas por dilatação térmica de lajes de cobertura são causadas pela existência de detalhes inapropriados no encontro entre as paredes e a laje de cobertura (cintamento muito rígido ou sistema de apoio deslizante). Neste caso ocorrerão fissuras de cisalhamento na alvenaria, nas proximidades da laje Figura 2.11).

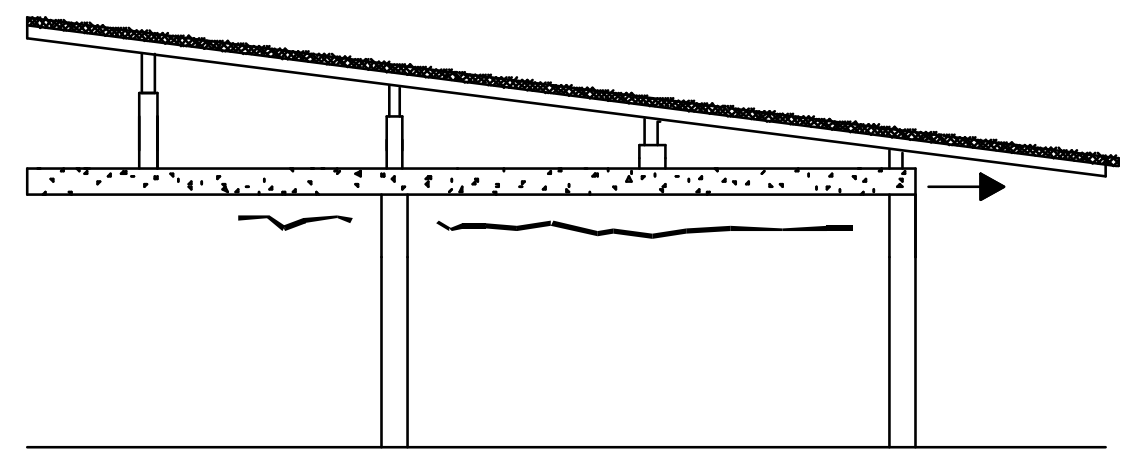

Figura 2.11 - Fissuras de cisalhamento na alvenaria. FONTE: THOMAZ (1990).

O comportamento das fundações afeta diretamente o desempenho das alvenarias. Recalques diferenciados ocorridos por falhas de projeto, rebaixamento do lençol freático, falta de homogeneidade do solo, consolidações diferenciadas de aterros, etc. contribuirão para o aparecimento de fissuras inclinadas em direção ao ponto onde ocorreu o maior recalque (Figura 2.12). Quando muito acentuado, ocorrem esmagamentos localizados, em forma de escamas, dando indícios das tensões de cisalhamento que os provocam (THOMAZ, 1990). 


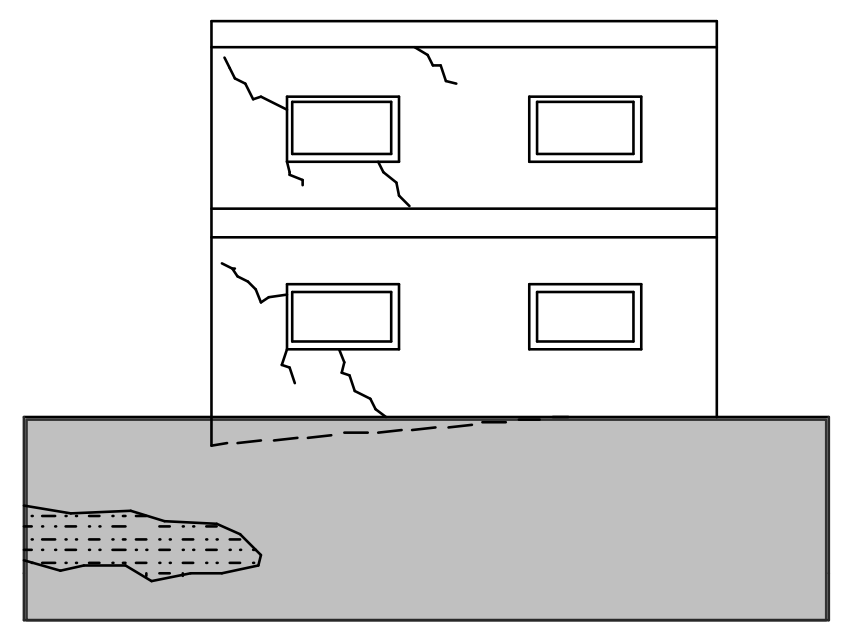

Figura 2.12 - Recalque diferenciado da fundação - adaptada de THOMAZ, 1990.

Em alvenarias estruturais as fissuras podem ser causadas por carregamentos desbalanceados, particularmente no caso de sapatas corridas ou vigas de fundação excessivamente flexíveis. Como exemplo (Figura 2.13), pode-se citar a sobrecarga que se encontra nas vizinhanças de grandes aberturas nas paredes, cujo trecho de alvenaria existente sob o vão acaba sendo solicitado à flexão, surgindo fissuras verticais nas proximidades do peitoril da janela (THOMAZ, 1990).

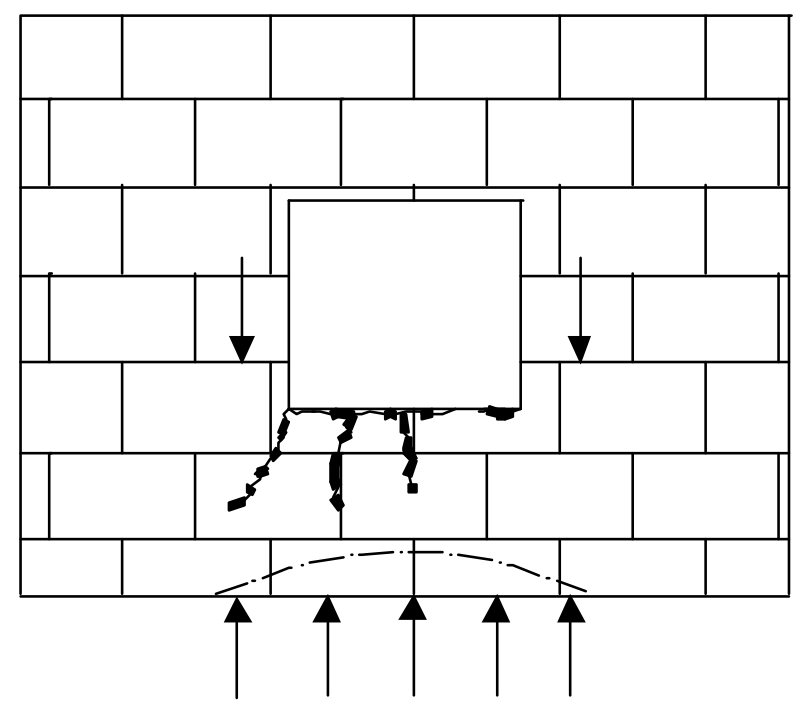

Figura 2.13 - Fundação contínua solicitada carregamento desbalanceado. 


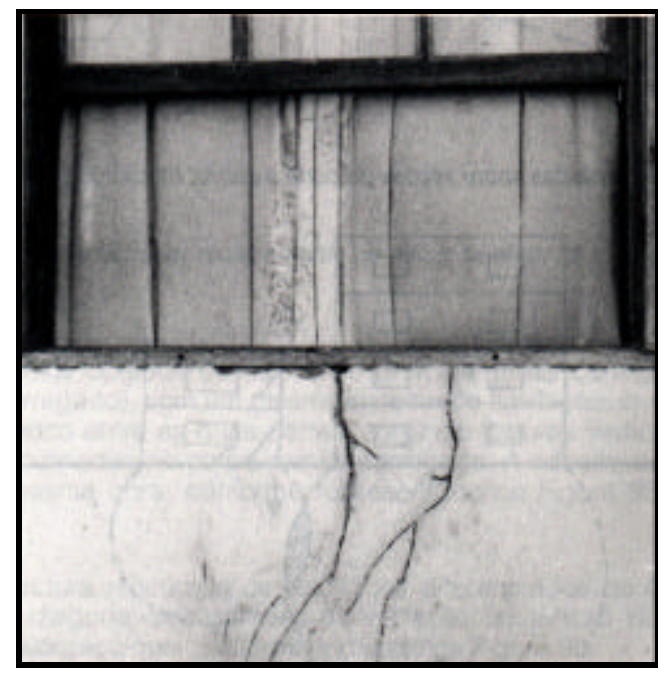

Figura 2.14 - Sob a abertura surgem fissuras de flexão.

GRIMM (1988) também ressalta que no caso de construções de alvenaria estrutural as fissuras são provavelmente a mais freqüente manifestação de perda de desempenho e podem ser causadas por diversos fatores como retração da argamassa, deformação de outras estruturas de concreto, expansão térmica diferenciada entre unidade de alvenaria e argamassa, recalque da fundação etc.. GRIMM destaca também que as fissuras podem acontecer devido às diferentes deformações ocorridas na interseção entre as paredes estruturais e as paredes de vedação. Neste caso, as fissuras se apresentam horizontalmente no meio da parede, devido à flexão causada por uma excessiva deformação de uma das paredes. Já as fissuras causadas por recalque de fundação são geralmente diagonais ou verticais.

\subsection{Reabilitação das alvenarias}

Como o estudo em questão propõe uma técnica de reabilitação de alvenaria, é necessário conhecer outras práticas também usadas para esse fim. Todas as referências que foram encontradas sobre esse assunto ressaltam que a melhor maneira de se prevenir um edifício da necessidade de reabilitações sérias é o dimensionamento e execução corretos. Assim, no dimensionamento deve-se considerar as solicitações necessárias para o cálculo da estrutura e, na execução, exigir-se um controle sistemático e eficiente da qualidade dos materiais e dos serviços. 
Como as alvenarias manifestam bom comportamento às solicitações de compressão deve-se evitar então, sempre que possível, cargas excêntricas e as cargas concentradas devem ser distribuídas por meio de coxins. As concentrações de tensão nas aberturas deverão ser absorvidas por vergas e contravergas. Deve-se evitar também, a presença de água na alvenaria acabada, pois provoca movimentações higroscópicas, eflorescências, expansão pela presença de sulfatos ou dissolução de compostos de argamassa de assentamento. Nestes casos, as providências a serem tomadas podem ser: impermeabilização da fundação, revestimento da parede com película impermeável ou hidrófuga e medidas que evitem o empoçamento de água nas bases das paredes.

Para D’Elia, apud DUARTE (1998) ${ }^{1}$, após a identificação da origem do problema, parte-se para as avaliações das conseqüências da anomalia e da evolução do fenômeno gerador. Chega-se então à conclusão de como e com que elementos será feita a recuperação. Se a questão envolver segurança, isto é, a perda de capacidade portante por solicitação mecânica, um reforço ideal para peças trincadas pode ser o emprego da protensão. Por outro lado, se o problema for relacionado à durabilidade, parte-se para a proteção aos agentes agressivos.

Segundo D'Elia, dentre os tratamentos convencionais de trincas "vivas" destacase os elásticos à base de poliuretanos, siliconados, polissulfetos e resinas acrílicas. Em caso de fissuras "mortas" os tratamentos com massa de resina epóxicas ou selantes rígidos. Diferentemente do primeiro, neste caso eles não precisam necessariamente ser injetados. Pode-se apenas fazer uma colmatação (cobrimento) superficial.

Quando as fissuras aparecem no revestimento de argamassa, SABBATINI (1998) afirma que estas podem ocorrer em função da amplitude de deformação da base, no caso da alvenaria de vedação. Para este autor não é função do revestimento absorver as deformações de grande amplitude da base. Na maioria dos casos a situação mais comum é que a fissuração do revestimento ocorra em virtude da própria fissuração da alvenaria, conforme LOGEAIS (1989). Sendo assim, faz-se

\footnotetext{
${ }^{1}$ D’Elia, AA. Engenheiro da Concrejato apud COSTA (1993) A linguagem das trincas. p. 16.
} 
necessário escolher um método de recuperação adequado para que a parede também seja tratada.

Nas alvenarias aparentes, os destacamentos entre componentes e argamassa de assentamento são recuperados pela escarificação das juntas, até uma profundidade de $15 \mathrm{~mm}$. Deve-se remover a poeira e materiais soltos, umedecer as juntas e preencher com argamassa de cimento; cal; areia no traço 1:2:9 (em volume) com solução de cola à base de resina PVA e água, na proporção de 1:2, também em volume.

Nas paredes de vedação danificadas por movimentações térmicas de lajes de cobertura ou pelo sobrecarregamento vindo da deformação dos componentes estruturais, é aconselhável a desvinculação entre o topo da parede e o componente estrutural (Figura 2.15).
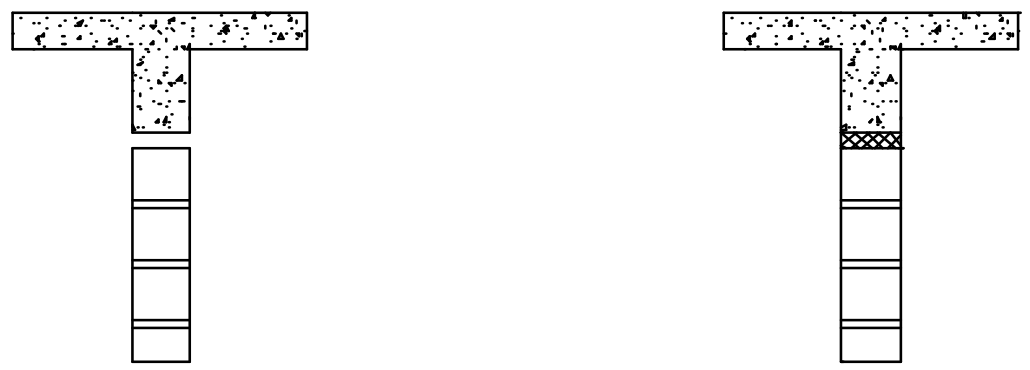

Figura 2.15 - Desvinculação entre a parede fissurada e o componente estrutural superior - extraída de THOMAZ, 1989.

Quando as lajes de cobertura sofrem dilatação térmica e estas são apoiadas em alvenaria portante, pode-se fazer o escoramento da laje, a remoção da última junta de assentamento e introduzir um material deformável. Quando não for possível o escoramento da laje de cobertura, a raspagem da junta $(\cong 10 \mathrm{~mm})$ é feita e preenchida com selante flexível.

THOMAZ (1989) afirma que as fissuras causadas por concentração de tensões só poderão ser recuperadas quando houver uma redistribuição de tensões no trecho carregado da parede. Uma saída é a colocação de coxins de distribuição convenientemente dimensionado.

Quando ocorrem destacamentos entre paredes e pilares ou vigas, a inserção de um material flexível (poliuretano expandido, feltro betumado, poliestireno expandido etc.) entre eles é a técnica mais utilizada. No caso de paredes revestidas pode-se, por exemplo, remover o revestimento numa largura de aproximadamente $25 \mathrm{~cm}$ para 
cada lado da fissura. A região deve ser limpa com uma trincha para remover poeiras e materiais soltos. É então fixada uma tela metálica de estuque traspassando $20 \mathrm{~cm}$ para cada lado, por meio de pregos ou cravos de metal. A tela deverá ficar medianamente distendida (Figura 2.16). Chapisca-se a alvenaria e o pilar ou viga e executa-se o revestimento com argamassa de cimento; cal; areia no traço de 1:2:9 em volume.

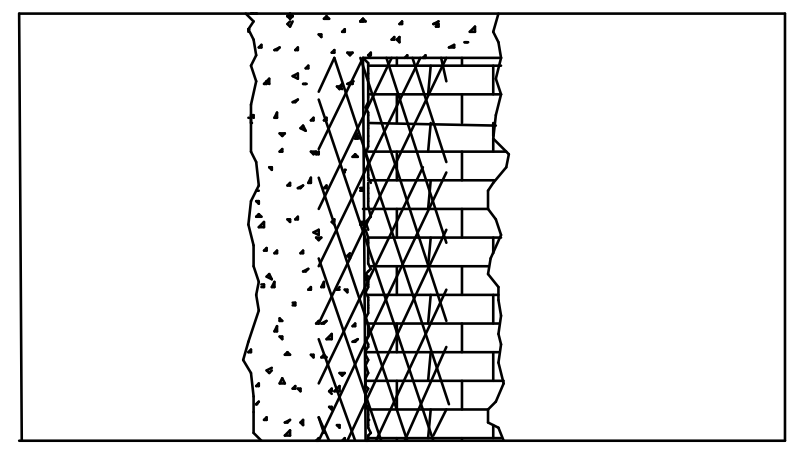

Figura 2.16- Recuperação de destacamento entre pilar e parede.

Em paredes longas com fissuras intermediárias pode-se criar juntas de movimentação ou a utilização de uma bandagem (Figura 2.17). Essa técnica consiste, por exemplo, em remover o revestimento numa faixa de aproximadamente $15 \mathrm{~cm}$, limpar a região e aplicar a bandagem com distribuição regular para ambos os lados da fissura. Chapisca-se toda a região onde fora removido o revestimento, inclusive sobre a bandagem e executa-se o revestimento com argamassa de cimento, cal hidratada e areia no traço de 1:2:9 em volume.

A técnica de bandagem também é utilizada nas fissuras em locais de enfraquecimento ou concentração de tensões na parede (cantos de aberturas, regiões de embutimento de tubulações etc.). As paredes são recuperadas superficialmente com a introdução de bandagem no revestimento ou de tela de náilon na pintura. Para recuperar o comportamento monolítico da parede, remove-se o revestimento original e introduz-se armaduras na alvenaria, no trecho fissurado. 


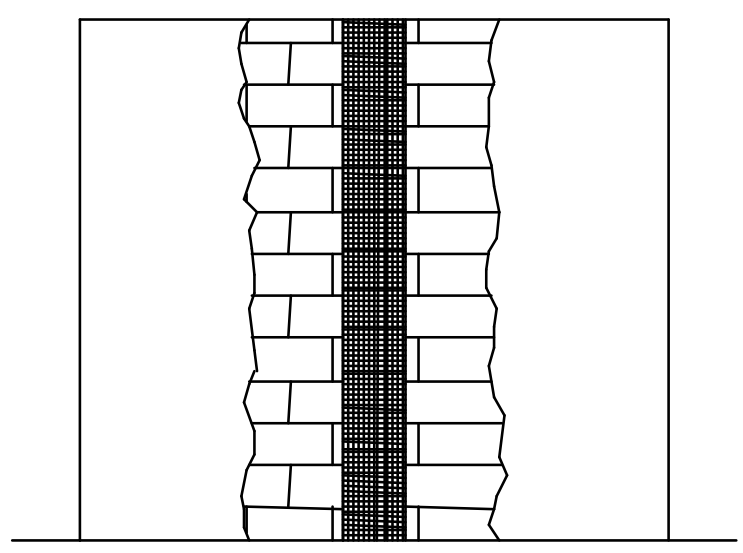

Figura 2.17 - Recuperação com bandagem.

Para reforço das paredes portantes trincadas, a introdução de armaduras chumbadas com argamassa rica em cimento e posicionadas perpendicularmente à fissura é uma das técnicas de reabilitação utilizadas. Para fissurações consideradas graves, como as causadas por recalques intensos da fundação pode-se recorrer ao atiramento da alvenaria (Figura 2.18).

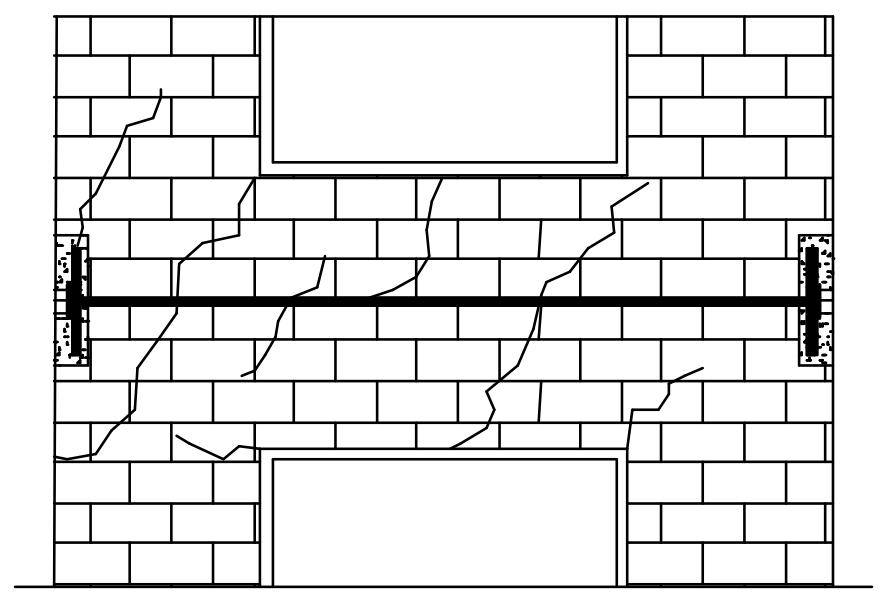

Figura 2.18 - Reforço de alvenaria portante com tirante de aço.

Nesta técnica, o tirante transmite seus esforços através de placas de aço apoiadas em superfície regularizada com argamassa. Deve-se proteger com argamassa aditivada de agente impermeabilizante o corpo e as extremidades rosqueadas do tirante, as placas de apoio e as porcas de fixação. Recomenda-se que no aperto das porcas o tirante deva estar aquecido, produzindo com seu resfriamento e conseqüente contração a compressão da alvenaria, THOMAZ (1989). 
Chama-se a atenção que a técnica aqui proposta para desenvolvimento corresponde à aplicação de revestimentos resistentes em toda a parede, não só recuperando a trinca, mas também reforçando a alvenaria como um todo. Com isso, espera-se não só aumentar a resistência, ductilidade e durabilidade, das paredes de alvenaria, como também utilizar a técnica em paredes com necessidades especiais de desempenho estrutural como reservatórios e muros de arrimo, etc.. 


\section{O USO DE REVESTIMENTOS RESISTENTES NA REABILITAÇÃO DE ESTRUTURAS DE ALVENARIA}

A argamassa armada vem sendo utilizada como um material de reparo e reforço tanto em estruturas de concreto como de alvenaria. Os resultados mostram um aumento de resistência, ductilidade e durabilidade das estruturas reabilitadas.

Um dos problemas mais questionáveis ao uso da argamassa armada é a sua pequena espessura podendo com isso, propiciar corrosão na armadura. Tal fato se deve à falta de cobrimento adequado quando se compara a argamassa armada com o concreto, tomando-se como base as recomendações da NBR-6118 (NB-1) "Projeto e execução de obras de concreto armado". Essas recomendações são, no entanto, de caráter geral e não devem ser tomadas como únicas, nem como as melhores para todas as situações. Isso poderia por exemplo, inviabilizar alguns processos construtivos que só são possíveis, técnica e comercialmente, utilizando-se cobrimentos inferiores aos considerados para o concreto (HELENE, 1986).

O cobrimento tem a finalidade de proteger fisicamente a armadura e propiciar um meio alcalino elevado que evite a corrosão por passivação do aço. Essa proteção depende, essencialmente das características e propriedades intrínsecas dos materiais considerados. Portanto, a diferentes "concretos" devem corresponder diferentes cobrimentos, mantido um mesmo nível de proteção (HELENE, 1986).

Para a argamassa armada, a qualidade da argamassa é essencial na proteção das armaduras contra corrosão, dependendo enfaticamente da relação água/cimento. Sendo assim, as argamassas empregadas em argamassa armada devem ter fator água/cimento baixos $(k 0,45)$, com adensamento eficiente e ser objeto de cura especialmente cuidadosa (HANAI, 1992). Tomando-se estes cuidados, a argamassa 
se mostra eficiente tanto como um componente construtivo, como um material de reparo/reforço.

REINHORN \& PRAWEL (1991) verificaram que um revestimento de argamassa armada acrescenta resistência e ductilidade em paredes de alvenaria nãoarmada. Os ensaios foram realizados em paredes de alvenaria de tijolo cerâmico, cujas dimensões eram de 20,33 x 8,89 x 6,35 cm, sendo que 2 não estavam revestidas e 5 estavam revestidas com argamassa armada utilizando-se telas de diferentes espaçamentos. Os modelos possuíam dimensões de 64,8 x 64,8 x 20,3 (Figura 3.1).

A argamassa de assentamento utilizada foi a indicada pela ASTM C 270-68 no traço de 1:1:1 apresentando resistência à compressão de 12,41 MPa.

A argamassa de revestimento usada foi preparada com traço de 1:2 (em volume) com fator $\mathrm{a} / \mathrm{c}=0,48$, resistência à compressão de 25,24 $\mathrm{MPa}$ e à tração de 3,56 $\mathrm{MPa}$. Os espaçamentos das telas variavam de $0,32 \mathrm{~cm}$ a $5,08 \mathrm{~cm}$ Na Tabela 3.1, estão sucintamente apresentadas as características dos modelos ensaiados.
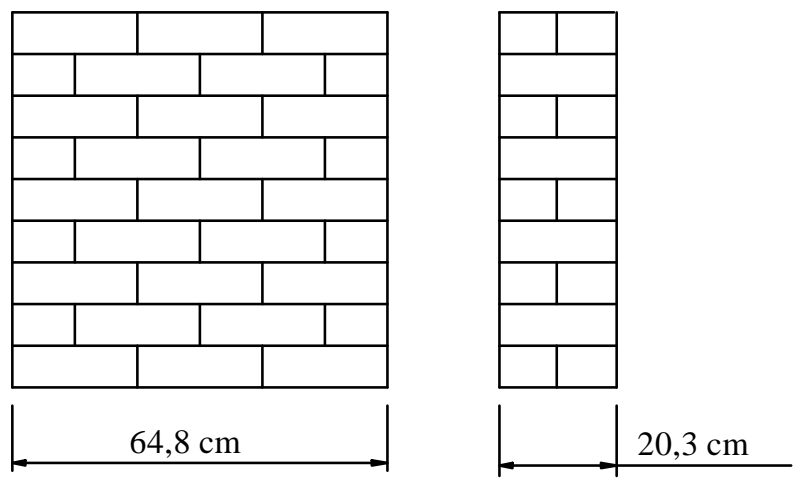

Figura 3.1 - Parede não revestida.

Tabela 3.1 - Revestimentos de argamassa armada

\begin{tabular}{ccccc}
\hline corpo-de-prova & $\mathrm{N}^{\mathrm{o}}$ de modelos & $\begin{array}{c}\text { espessura } \\
(\mathrm{cm})\end{array}$ & $\begin{array}{c}\text { tamanho da } \\
\text { malha }(\mathrm{mm})\end{array}$ & $\begin{array}{c}\text { diâmetro dos } \\
\text { fios }(\mathrm{mm})\end{array}$ \\
\hline B1-SBM & 2 & - & - & - \\
SZ1-SBF & 1 & 1,55 & $12,7 \times 12,7$ & 1,06 \\
SZ2-SBF & 1 & 1,55 & $25,4 \times 25,4$ & 1,52 \\
SZ3-SBF & 1 & 1,55 & $50,8 \times 50,8$ & 1,90 \\
SZ4-SBF & 1 & 1,27 & $6,4 \times 6,4$ & 0,68 \\
SZ5-SBF & 1 & 1,27 & $3,2 \times 3,2$ & 0,48 \\
\hline
\end{tabular}


O revestimento foi aplicado depois de 14 dias da execução das paredes e os ensaios realizados depois de 28 dias. As telas eram fixadas por arames que atravessavam as paredes em pontos espaçados de aproximadamente 20,32 cm (Figura 3.2).

Observou-se que as paredes que possuíam telas com uma malha fina, a penetração da argamassa era mais difícil. O ensaio realizado foi o de compressão diagonal aplicando-se carregamento dinâmico nos corpos-de-prova analisados. O esquema do ensaio pode ser visto na Figura 3.3. A Figura 3.4 representa o gráfico força $\mathrm{x}$ deslocamento dos modelos ensaiados.
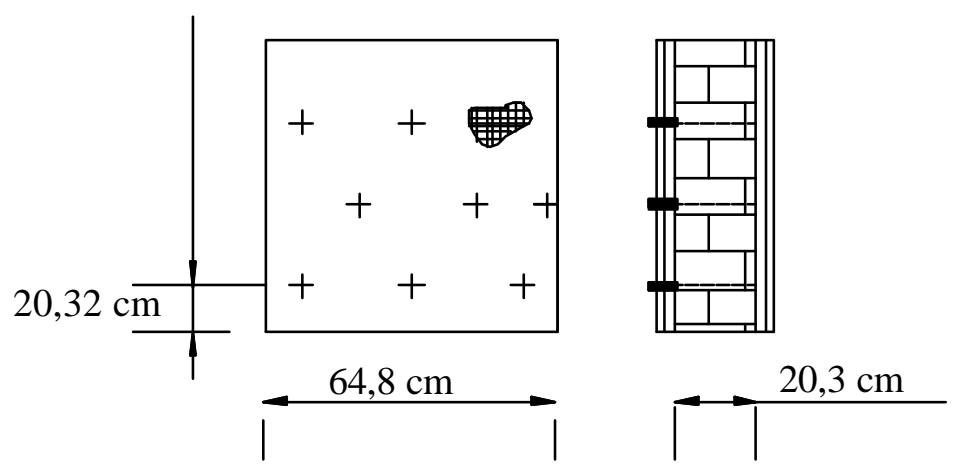

Figura 3.2 - Parede revestida.

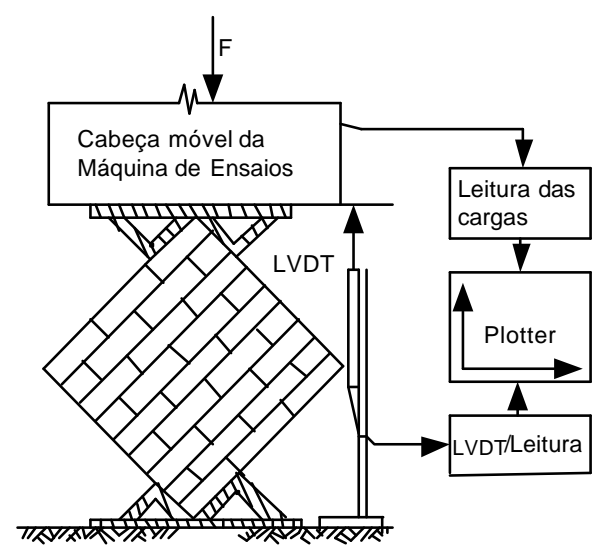

Figura 3.3- Esquema do ensaio de compressão diagonal. 


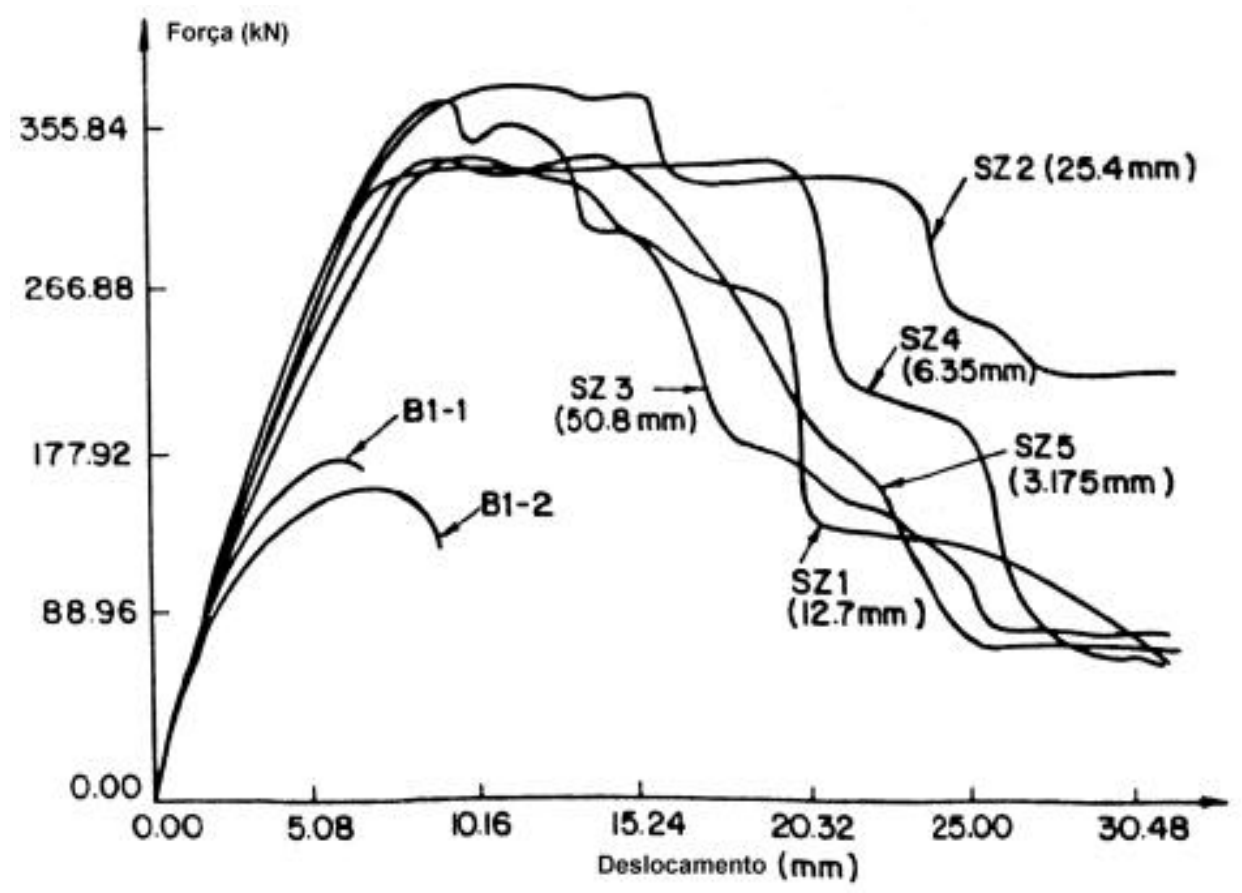

Figura 3.4 - Resultados dos ensaios - extraída de REINHORN \& PRAWEL (1991).

Analisando-se o gráfico da Figura 3.4, observa-se que nas paredes revestidas ganharam resistência e ductilidade. Depois do aparecimento considerável de fissuras, ocorria a separação entre as placas de argamassa armada e a alvenaria. As placas de revestimento rompiam à compressão com um esmagamento localizado nos cantos, condição também apresentada em ensaios realizados por JIA apud REINHORN (1985) ${ }^{2}$.

SINGH et al. (1988) realizaram ensaios em colunas de blocos cerâmicos de alvenaria encamisados com argamassa armada. O objetivo do ensaio era verificar a força da primeira fissura e força de ruptura.

As colunas foram envoltas com telas, fixadas por conectores em $\mathrm{U}$ e, algumas delas simplesmente amarradas. Foi aplicada então, argamassa rica com traços 1:1,5 e 1:2,5 para aderência entre a tela e as colunas. As 15 colunas ensaiadas em 5 situações diferentes, possuíam dimensões de 22,5 x 22,5 x $90 \mathrm{~cm}$.

\footnotetext{
2 JIA,Z.H. (1984) Seismic retrofit of structural masonry walls apud REINHORN,A.M.;PRAWEL,S.P.
} (1985). p. 167. 
Os modelos foram ensaiados entre 6 a 7 semanas depois de revestidos. Todos os corpos de prova foram ensaiados à compressão axial. Na Tabela 3.2 estão descritas as condições das colunas para ensaio.

Tabela 3.2 - Descrição dos corpos-de-prova ensaiados

\begin{tabular}{cccc}
\hline \multirow{2}{*}{ Corpo-de-prova } & \multicolumn{2}{c}{ revestimento } & \multirow{2}{*}{ telas } \\
\cline { 2 - 3 } & espessura & traço & - \\
P1, P2, P3 & - & - & - \\
A4, A5, A6 & $1 \mathrm{~cm}$ & $1: 6$ & - \\
B4, B5, B6 & $1 \mathrm{~cm}$ & $1: 2$ & - \\
A1, A2, A3 & 2 a $2,5 \mathrm{~cm}$ & $1: 6$ & 2 camadas $-\phi 1 \mathrm{~mm}$ \\
B1, B2, B3 & 2 a $2,5 \mathrm{~cm}$ & $1: 2$ & $\phi 5 \mathrm{~mm}$ \\
\hline
\end{tabular}

Como era esperado, a carga de ruptura foi mais baixa para as colunas não revestidas e mais alta (mais que o dobro) para as colunas revestidas com argamassa armada com traço de 1:2. Comparando-se os resultados das colunas A1-A3 e B1-B3 verifica-se uma grande diferença no valor da carga de ruptura, enquanto que entre as colunas A4-A6 e B4-B6 essa diferença é menor.

As primeiras fissuras nas colunas não revestidas foram observadas quando 0 valor da carga aplicada atingia $75 \%$ a $80 \%$ da carga máxima. Fissuras verticais atravessavam as juntas da argamassa de assentamento e dos blocos, enquanto que fissuras horizontais eram observadas apenas nas juntas dos blocos. Nas colunas revestidas apenas com argamassa, as fissuras ocorreram quando se atingia $65 \%$ a 75\% da carga máxima. Neste caso, as fissuras abriam-se mais rapidamente e pedaços de argamassa descolavam das colunas.

O quadro de fissuras apresentado nas colunas revestidas de argamassa armada era totalmente diferente das outras situações analisadas. Estas ocorreram de $55 \%$ a $65 \%$ da carga máxima nas colunas A1-A3, e de $40 \%$ a 50\% nas colunas B1-B3. Embora as fissuras aparecessem com cargas bem próximas que nas outras situações, eram superficiais, predominantemente verticais e ocorriam no centro e topo das colunas. As aberturas das fissuras centrais aumentavam consideravelmente de acordo com a carga aplicada e estendiam-se até quase o final do comprimento das colunas. O gráfico da Figura 3.5 e a Tabela 3.3 apresentam os resultados obtidos nos ensaios. 


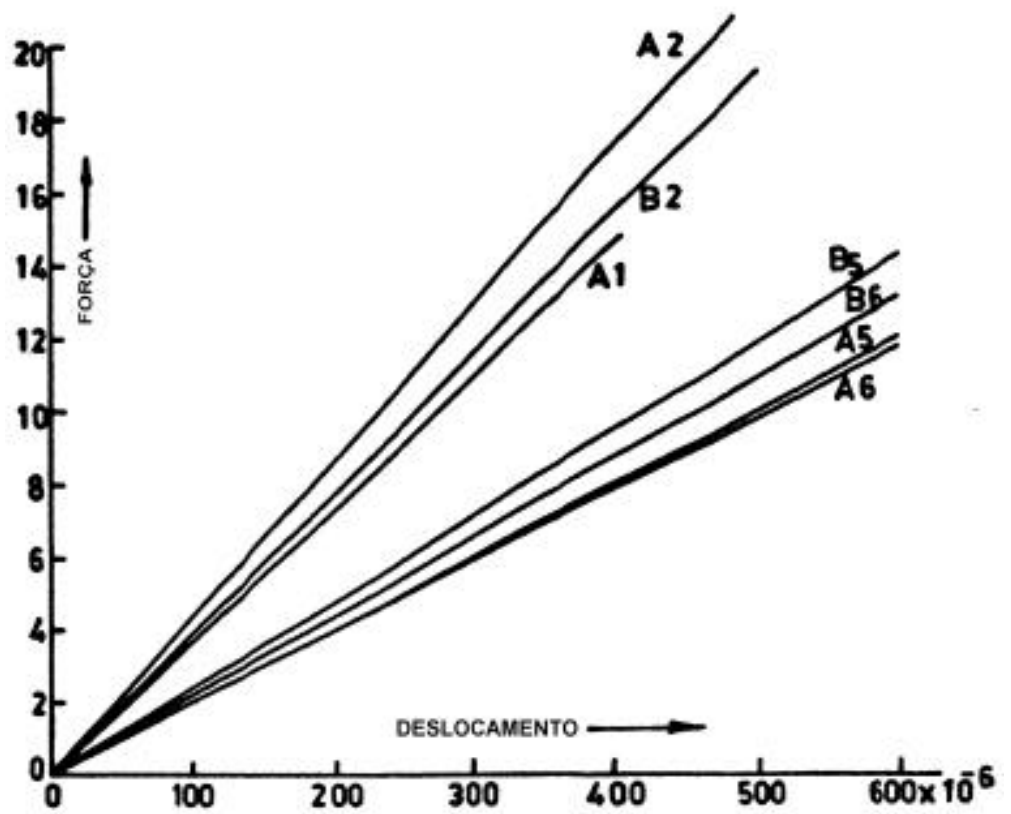

Figura 3.5 - Gráfico força x deslocamento dos ensaios realizados, extraído de SINGH et al. (1988).

Tabela 3.3 - Resultados dos ensaios (SINGH et al.,1988).

\begin{tabular}{|c|c|c|c|c|}
\hline corpo-de-prova & $\begin{array}{l}\text { carga da } 1^{\mathrm{a}} \\
\text { fissura }(\mathrm{T})\end{array}$ & $\begin{array}{c}\text { carga de } \\
\text { ruptura }(\mathrm{T})\end{array}$ & média & $\begin{array}{c}\text { aumento de } \\
\text { carga }(\%)\end{array}$ \\
\hline P1 & 10 & 13,5 & \multirow{3}{*}{12,7} & \multirow{3}{*}{ - } \\
\hline $\mathrm{P} 2$ & 9,5 & 11,5 & & \\
\hline P3 & 10,25 & 13 & & \\
\hline A4 & 10 & 13 & \multirow{3}{*}{13,7} & \multirow{3}{*}{8} \\
\hline A5 & 10 & 15,5 & & \\
\hline A6 & 12 & 12,5 & & \\
\hline B4 & 12 & 15,5 & \multirow{3}{*}{15,8} & \multirow{3}{*}{24,6} \\
\hline B5 & 12 & 17 & & \\
\hline B6 & 12 & 15 & & \\
\hline A1 & 12 & 20 & \multirow{3}{*}{19,5} & \multirow{3}{*}{53,5} \\
\hline $\mathrm{A} 2$ & 12 & 21 & & \\
\hline $\mathrm{A} 3$ & 12 & 17,5 & & \\
\hline B1 & 14 & 29 & \multirow{3}{*}{29,4} & \multirow{3}{*}{131} \\
\hline B2 & 12 & 29,75 & & \\
\hline B3 & 12 & 29,5 & & \\
\hline
\end{tabular}


SINGH et al. (1988) concluíram com este estudo que:

a) O encamisamento de colunas de alvenaria com argamassa armada pode aumentar mais que o dobro a carga de ruptura;

b) Uma ruptura prematura pode ocorrer, se a malha não envolver adequadamente as colunas e a argamassa não penetrar entre as aberturas para proporcionar aderência entre os componentes;

c) A ruptura ocorre com a expansão lateral das colunas, com conseqüente colapso do encamisamento.

CAVALHEIRO \& MÜLLER (1991) estudaram a influência do revestimento na resistência de pequenas paredes de blocos cerâmicos comuns. Os autores ressaltam que os blocos cerâmicos comuns, tipo vedação (furos na horizontal), têm sido empregados empiricamente em paredes com função resistente de prédios de baixa altura, causando incertezas quanto à segurança estrutural destes. Analisam também, principalmente o efeito do revestimento na resistência à compressão axial e no módulo de deformação de pequenas paredes, quantificando os acréscimos nestas características.

Foram executadas para cada uma das duas possibilidades de assentamento dos blocos - sobre a menor face e a maior face - com furos na horizontal, 2 séries de 9 pequenas paredes: uma sem revestimento e outra com revestimento dos dois lados, totalizando, assim, 36 corpos de prova de pequenas paredes. A argamassa utilizada tanto para assentamento como para revestimento foi de 1:2:11 (cimento:cal:areia) em volume e apresentou aos 28 dias resistência média de 0,70 MPa.

Para cada tipo de assentamento foram confeccionados, igualmente, 15 prismas de 2 blocos superpostos e 15 prismas de 3 blocos superpostos, num total, portanto, de 60 prismas, sendo 24 ensaiados aos 7 dias e 36 aos 28 dias de idade.

Quanto às unidades, foram ensaiadas 15 em cada posição, num montante de 30 blocos. Para cada pequena parede foram moldados 2 corpos de prova de argamassa de assentamento, para ruptura na data de ensaio da parede.

Os resultados obtidos estão demonstrados na Tabela 3.4 onde estão apresentados as características de deformabilidade das pequenas paredes com e sem revestimento. 
O módulo de deformação longitudinal foi calculado com base na média das variações de encurtamento, correspondentes a iguais variações de carga.

Quanto à quantificação do acréscimo de resistência obtido quando a pequena parede (PPs) é revestida, as PPs com blocos assentados na menor face aumentaram em $22 \%$ a resistência de ruptura. Este valor é aproximadamente o mesmo obtido para as pequenas paredes com blocos comprimidos na maior face (24\%). O revestimento aumentou em $70 \%$ o módulo de deformação das PPs mais estreitas e em apenas 32\% nas de blocos assentados com a face maior. Desta forma, o revestimento aumentou a rigidez e a resistência das pequenas paredes, porém não na mesma proporção.

Tabela 3.4 - Resultados obtidos nos ensaios de pequenas paredes.

Influência do revestimento na resistência e na deformação das pequenas paredes.

\begin{tabular}{|c|c|c|c|c|c|c|c|c|c|}
\hline \multicolumn{2}{|c|}{ Pequena parede } & \multirow{2}{*}{$\begin{array}{c}\begin{array}{c}\text { Resistên- } \\
\text { cia média }\end{array} \\
\mathrm{f}_{\mathrm{ppa}}\end{array}$} & \multicolumn{2}{|c|}{$\begin{array}{l}\text { Módulo de } \\
\text { deformação } \\
\text { médio }\end{array}$} & \multicolumn{5}{|c|}{ Relações adimensionais médias } \\
\hline Assentamento & Tipo & & $\mathrm{E}_{\mathrm{ppa}}$ & $\mathrm{CV}$ & fppa & $f_{\text {ppa }}$ & $f_{p p a}$ & $\operatorname{Eppa}(\mathrm{CR})$ & $\mathrm{fppa}(\mathrm{CR})$ \\
\hline dos blocos & & $(\mathrm{MPa})$ & $(\mathrm{MPa})$ & $(\%)$ & $\mathrm{fb}$ & $\overline{f_{p(2)}}$ & $\overline{f_{p}(3)}$ & $\overline{\mathrm{Eppa}(\mathrm{SR})}$ & fppa(SR) \\
\hline Face menor & SR & 1,38 & 546 & 10,1 & 0,75 & 0,83 & 0,90 & 1,70 & 1,22 \\
\hline (pé) & $\mathrm{CR}$ & 1,68 & 927 & 12,6 & 0,92 & 1,01 & 1,10 & & \\
\hline Face maior & SR & 1,11 & 568 & 7,5 & 0,44 & 0,70 & 0,67 & 1,32 & 1,24 \\
\hline (deitado) & $\mathrm{CR}$ & 1,38 & 749 & 11,9 & 0,55 & 0,87 & 0,84 & & \\
\hline \multicolumn{10}{|c|}{$\mathrm{f}_{\mathrm{b}}$ : resistência média à compressão dos blocos; } \\
\hline \multicolumn{10}{|c|}{$\mathrm{f}_{\mathrm{p}(2)}$ : resistência média à compressão dos prismas de 2 blocos; } \\
\hline \multicolumn{10}{|c|}{$\mathrm{f}_{\mathrm{p}(3)}$ : resistência média à compressão dos prismas de 3 blocos; } \\
\hline \multicolumn{10}{|c|}{$\mathrm{f}_{\mathrm{ppa}}$ : resistência média à compressão das pequenas paredes; } \\
\hline \multicolumn{10}{|c|}{$\mathrm{E}_{\mathrm{ppa}}$ : módulo de deformação longitudinal médio das pequenas paredes; } \\
\hline \multicolumn{10}{|c|}{ SR e CR: sem e com revestimento, respectivamente. } \\
\hline
\end{tabular}

Como nas pequenas paredes ensaiadas os blocos de vedação utilizados eram de baixa resistência à compressão e com furos posicionados horizontalmente, a fissuração nas paredes não revestidas pareceu ter iniciado, na maioria das vezes, a partir de um furo em direção ao vinco lateral mais próximo (Figura 3.6a). Em alguma destas PPs não revestidas, da série mais esbelta, observou-se nas faces 
laterais fissuras verticais entre os furos (Figura 3.6b) estendendo-se, posteriormente, à argamassa. Estas fissuras possivelmente foram originadas da tração indireta ocorrida na parede central do bloco face à compressão deste.

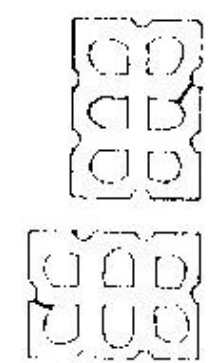

(a)

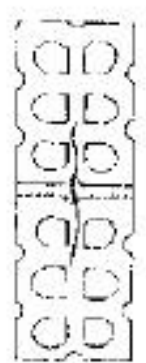

(b)

Figura 3.6 - Fissuras observadas nas faces laterais dos blocos das paredes nãorevestidas - extraída de CAVALHEIRO \& MÜLLER (1991).

Nas paredes revestidas, além de fissuras em direção ao vinco Figura 3.7.a 26.a) foram percebidas, em maior número de vezes, nas faces laterais, fissuras verticais entre furos (Figura 3.7.b) ou nas partes inferior e superior destes (Figura 3.7.c), como se o bloco fosse um conjunto de pequenos tubos comprimidos diametralmente. Esta mesma hipótese, pode esclarecer a fissuração que vai do furo em direção ao vinco, a qual é mais evidenciada ainda em blocos com furos perfeitamente circulares e contendo vincos. A Figura 3.8 indica um dos poucos casos em que houve descolamento do revestimento, possivelmente ocasionado por ocorrência de uma flexo-compressão originada por excentricidade não prevista da carga.

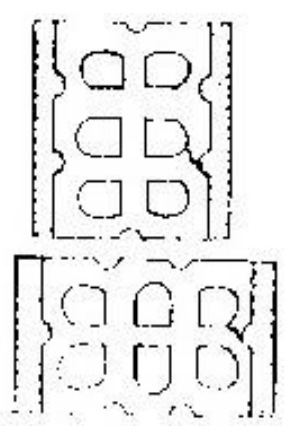

(a)

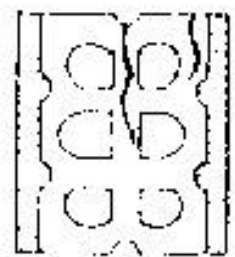

(b)

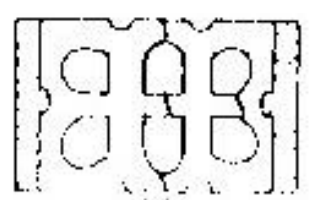

(c)

Figura 3.7 - Tipos de fissuras encontradas nas paredes revestidas - extraída de

CAVALHEIRO \& MÜLLER (1991). 


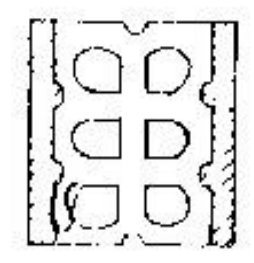

Figura 3.8 - Fissuras que ocasionavam o descolamento do revestimento - extraída de CAVALHEIRO \& MÜLLER (1991).

Nenhuma fissura foi observada, antes da ruptura, nas faces principais das pequenas paredes. Somente nas faces laterais pôde-se perceber o seu aparecimento e crescimento em um razoável número de corpos-de-prova. A ruptura em mais de $60 \%$ dos casos se deu de maneira brusca ("explosiva") denotando a fragilidade da forma de ruptura do material. Isto indica, por outro lado, que a resistência da argamassa adotada, apesar de baixa $(0,70 \mathrm{MPa})$, mostrou-se suficiente para a compressão axial sofrida, atribuindo-se a ruptura das pequenas paredes ao colapso dos blocos.

IRIMIES \& CRAINIC (1993) investigaram paredes de alvenaria danificadas e recuperadas com injeção de pasta de cimento nas fissuras e reforçadas pela aplicação de revestimentos resistentes armados.

A metodologia de recuperação consistia em preencher as fissuras com pasta de cimento e depois aplicar um revestimento de $30 \mathrm{~mm}$ de espessura nas duas faces da parede. A argamassa do revestimento foi reforçada com telas de aço com fios $\phi 6$ $\mathrm{mm}$, espaçados de $250 \mathrm{~mm}$ e resistência de $280 \mathrm{MPa}$.

A outra alternativa investigada foi a de aplicar o revestimento por meio de uma bomba (argamassa projetada) nas duas faces da parede, mas sem o reparo nas fissuras. O revestimento era de $30 \mathrm{~mm}$ de espessura e reforçado com telas de aço com fios de $\phi 4 \mathrm{~mm}$ espaçados de $200 \mathrm{~mm}$, com resistência de $500 \mathrm{MPa}$. Nenhum conector foi usado para fixar a tela na parede de alvenaria. Foram construídos seis modelos e submetidos a cargas laterais até a ruína. 

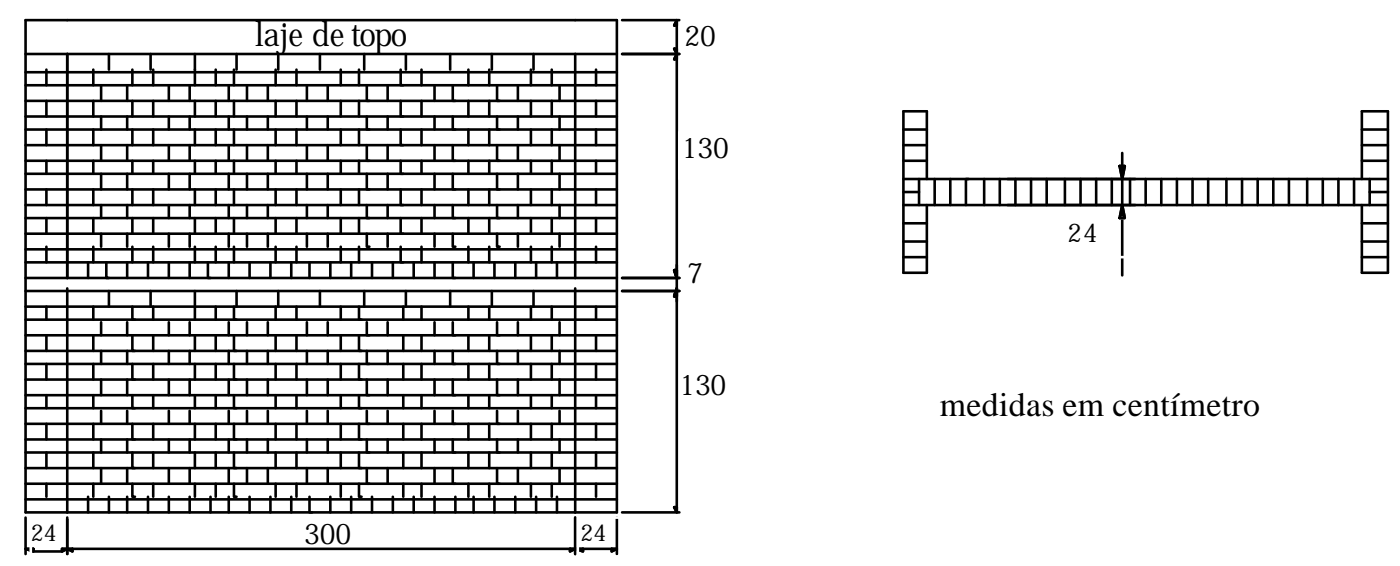

medidas em centímetro
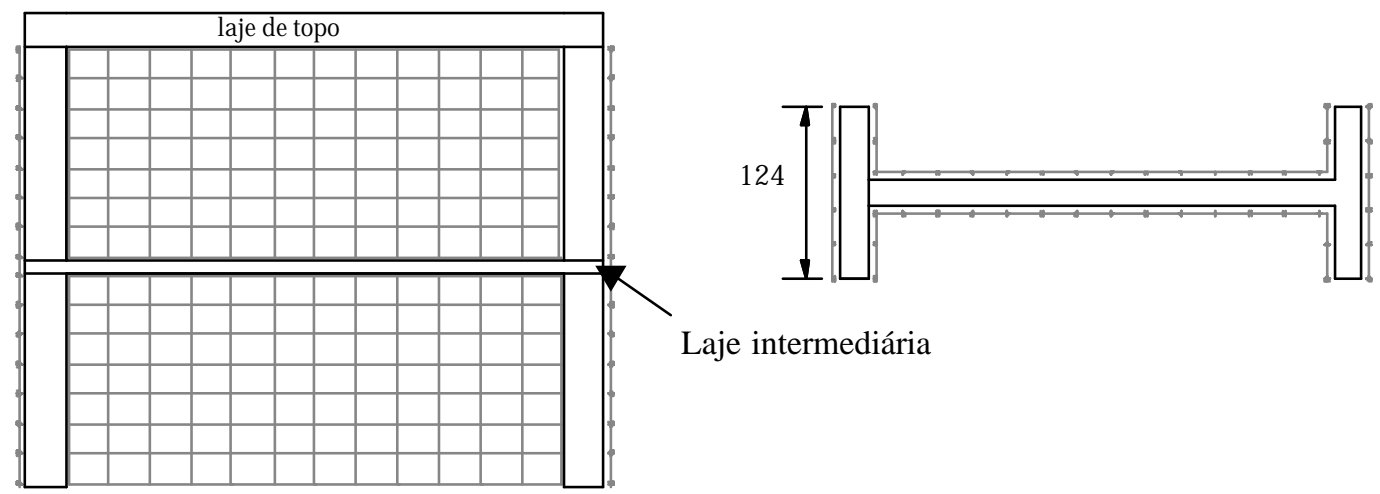

Figura 3.9 - Descrição dos modelos ensaiados (com telas) - extraída de IRIMIES \& CRAINIC (1993).

Os modelos foram construídos com tijolos cerâmicos maciços e apresentaram resistência média à compressão igual a $10 \mathrm{MPa}$. A argamassa de assentamento era de cimento, cal e areia no traço de 1:2,8:13 (em volume) com resistência à compressão de 1,00 MPa. As paredes foram construídas com flanges para que o comportamento das telas pudessem ser avaliados sob forças de cisalhamento elevadas. As paredes P1, P2 e P3 foram previamente danificadas e depois recuperadas. O modelo $\mathrm{P} 2 \mathrm{~s}$ foi recuperado com pasta de cimento nas fissuras e aplicação de revestimento, o modelo $\mathrm{P} 3 \mathrm{~s}$ foi recuperado com aplicação de argamassa projetada e duas paredes do modelo P1s foram recuperados por injeção de pasta de cimento nas fissuras, mas sem aplicação de revestimento.

O carregamento vertical aplicado foi constante enquanto se variavam (aumentando) as forças laterais. A força vertical aplicada proporcionava uma tensão de 0,25 MPa no topo da parede. A configuração das fissuras nas paredes pode ser observada na Figura 3.10. 


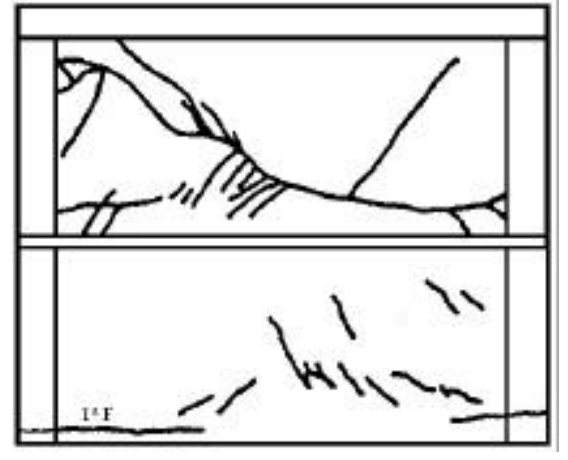

P1
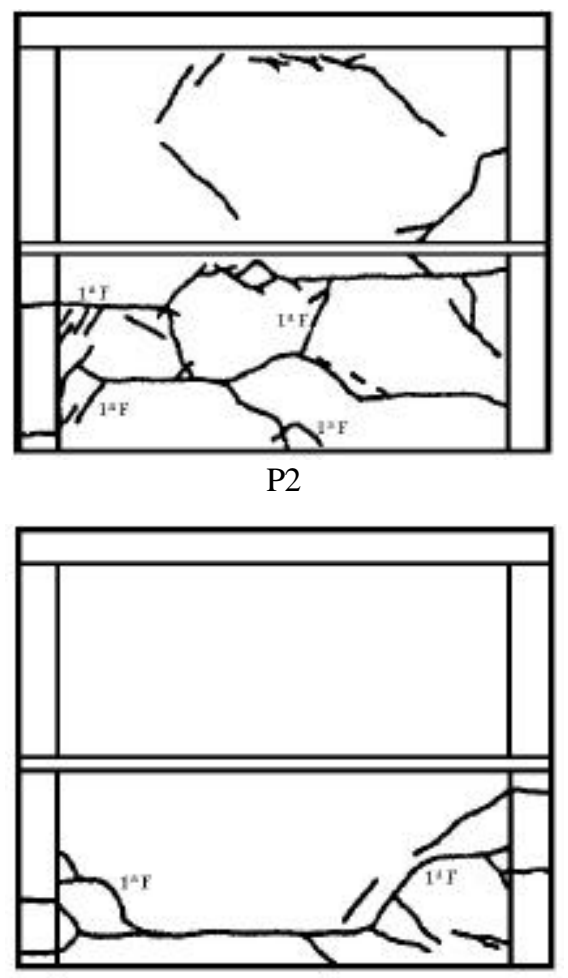

P3

(a) paredes sem danos.

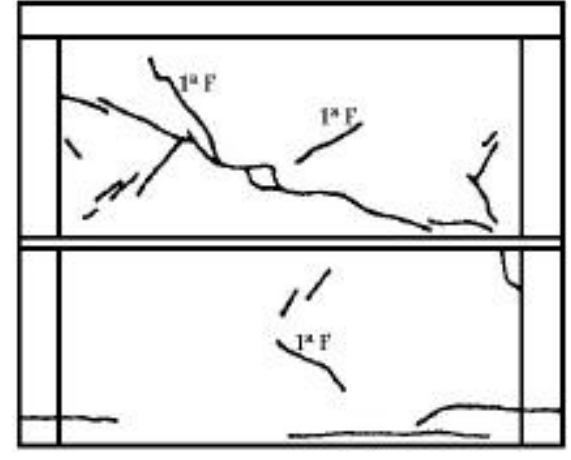

P1s

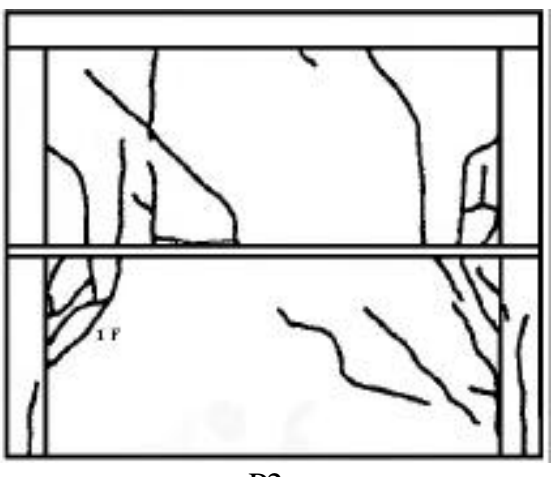

$\mathrm{P} 2 \mathrm{~s}$

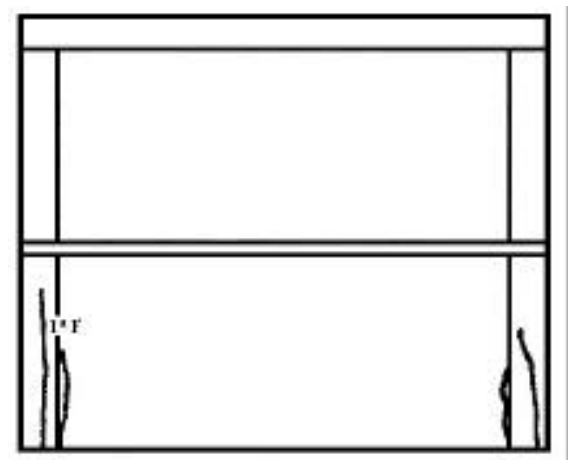

P3s

(b) paredes reabilitadas

Figura 3.10 - Fissuração das paredes ensaiadas - extraída de IRIMIES \& CRAINIC (1993).

Como resultado observou-se que o comportamento das paredes ensaiadas sem danos prévios foi igual no que se refere ao aparecimento das primeiras fissuras. De modo geral apareciam fissuras horizontais nas flanges e fissuras diagonais nos planos das paredes.

Foram também observadas fissuras nas juntas de argamassa. Verificou-se que depois do aparecimento das fissuras, a força aplicada não sofria nenhum acréscimo, 
permanecia constante. Depois de danificadas as paredes foram reabilitadas e ensaiadas novamente .

As paredes reabilitadas com preenchimento das fissuras com pasta de cimento (P1s) romperam-se com a mesma força que atingiram antes de serem recuperadas. $\mathrm{O}$ comportamento foi similar ao das paredes ensaiadas sem danos.

Quanto aos dois métodos de reabilitação utilizados, ambos proporcionaram aumento na rigidez da parede. Durante os ensaios, observou-se uma distorção na base das paredes, que depois de restringida ocasionou uma concentração de fissuras na flange comprimida.

Fissuras verticais apareceram no revestimento na face externa da flange comprimida causando destacamento da alvenaria, como também nos blocos, nas juntas das flanges e no encontro das flanges com o plano da parede.

$\mathrm{O}$ comportamento da parede reabilitada com argamassa projetada $(\mathrm{P} 3 \mathrm{~s})-$ sem preenchimento das fissuras com pasta de cimento - foi igual ao das paredes reabilitadas com o preenchimento das fissuras com pasta de cimento (P1s).

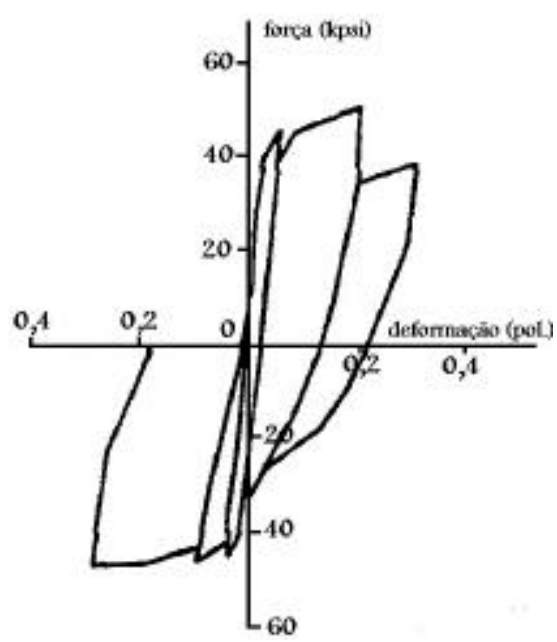

P1

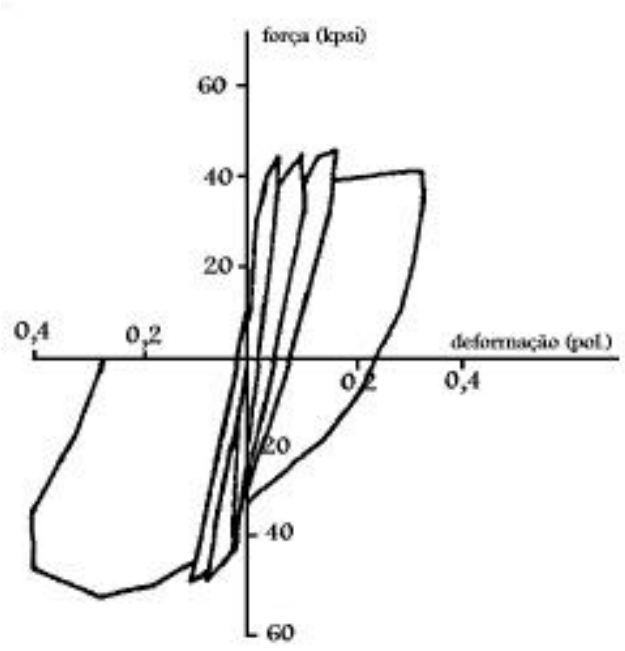

P1s

Figura 3.11 Gráfico força x deslocamento das paredes P1 e P1s. 


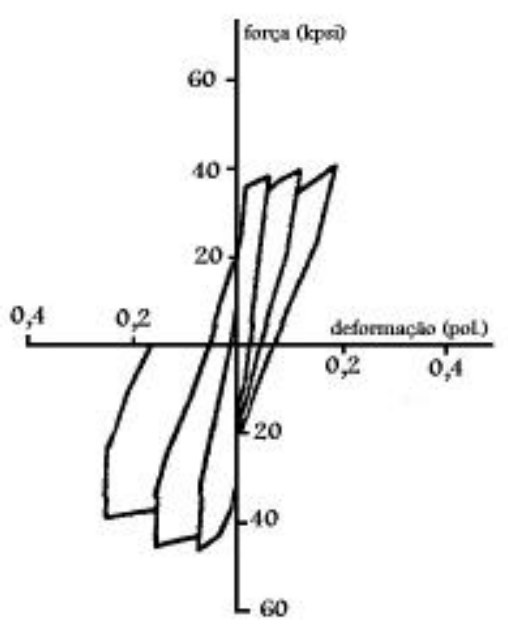

P2

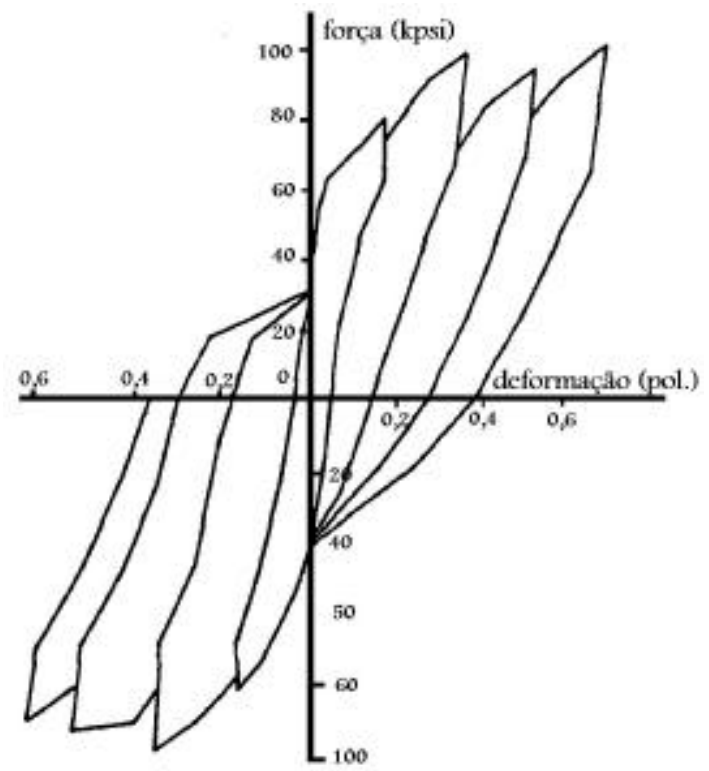

$\mathrm{P} 2 \mathrm{~s}$

Figura 3.12 Gráfico força x deslocamento das paredes P2 e P2s.

JABAROV et al. (1985) realizaram o mesmo estudo em paredes de alvenaria de tijolo com aberturas. O modelo depois de danificado foi rebocado com revestimento de aproximadamente $25 \mathrm{~mm}$ de espessura e reforçado com telas de aço ou barras posicionadas na diagonal.

Duas paredes paralelas com aberturas eram submetidas a forças estáticas laterais. Os modelos tinham dimensões de 5,6 m de altura por 7,0 $\mathrm{m}$ de comprimento, e $38 \mathrm{~cm}$ de espessura. As paredes estavam unidas por uma laje de concreto de $10 \mathrm{~cm}$ de espessura, tanto no primeiro como no segundo andar, onde eram aplicadas as cargas laterais.

Depois de danificadas, as paredes sem revestimento receberam uma camada de argamassa nas paredes $\mathbf{1}$ e $\mathbf{2}$ de cada andar dos modelos. Barras posicionadas na diagonal eram colocadas nas paredes 1 e 2 (Figura 3.13) e cobertas pelo revestimento de argamassa. Depois de ensaiada nessa condição, a parede $\mathbf{3}$ foi reforçada com tela soldada de 200 x $200 \mathrm{~mm}$ fixada junto com o revestimento. Nessa última situação, em alguns incrementos era aplicada uma força dinâmica para conhecimento das características dinâmicas do modelo (freqüência e taxa de diminuição da amplitude). 


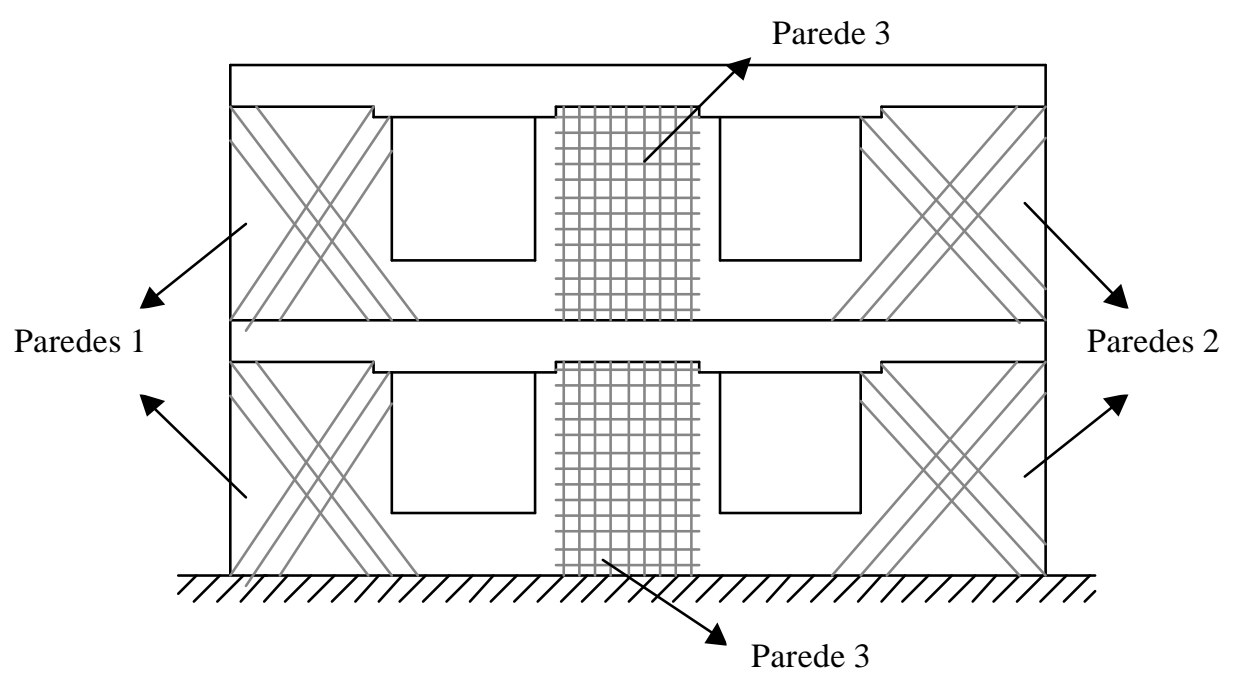

Figura 3.13 - Reforço utilizados nas paredes - adaptada de JABAROV et al. (1985).

JABAROV et al. concluíram que a resistência e a rigidez de paredes reforçadas com revestimentos depende da espessura do revestimento, da resistência da argamassa e da taxa de armadura utilizada. A configuração das fissuras nas paredes ensaiadas está demonstrada nas figuras a seguir.

Observou-se que nas paredes não-revestidas, as primeiras fissuras apareceram aproximadamente a $2 / 3$ da carga de ruptura. As fissuras se prolongavam na diagonal e a carga máxima atingida foi de $910 \mathrm{kN}$.

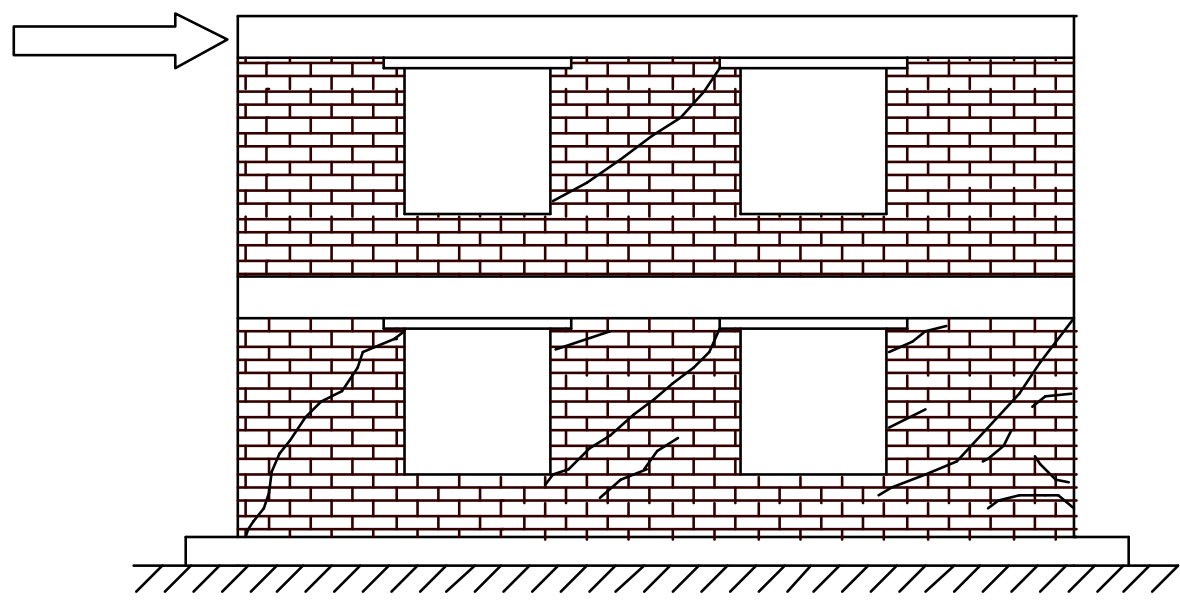

Figura 3.14 - Modelo ensaiado sem revestimento - extraída de JABAROV et al. (1985). 
Depois de reforçadas as paredes 1 e 2 , o valor da força lateral aumentou para $1175 \mathrm{kN}$. Pequenas fissuras foram observadas aproximadamente a 1/3 da carga máxima alcançada. Na terceira condição ensaiada - (parede 3) reforçada com telas soldadas - a carga atingida foi 2,9 vezes maior que o valor atingido nas paredes sem revestimento.

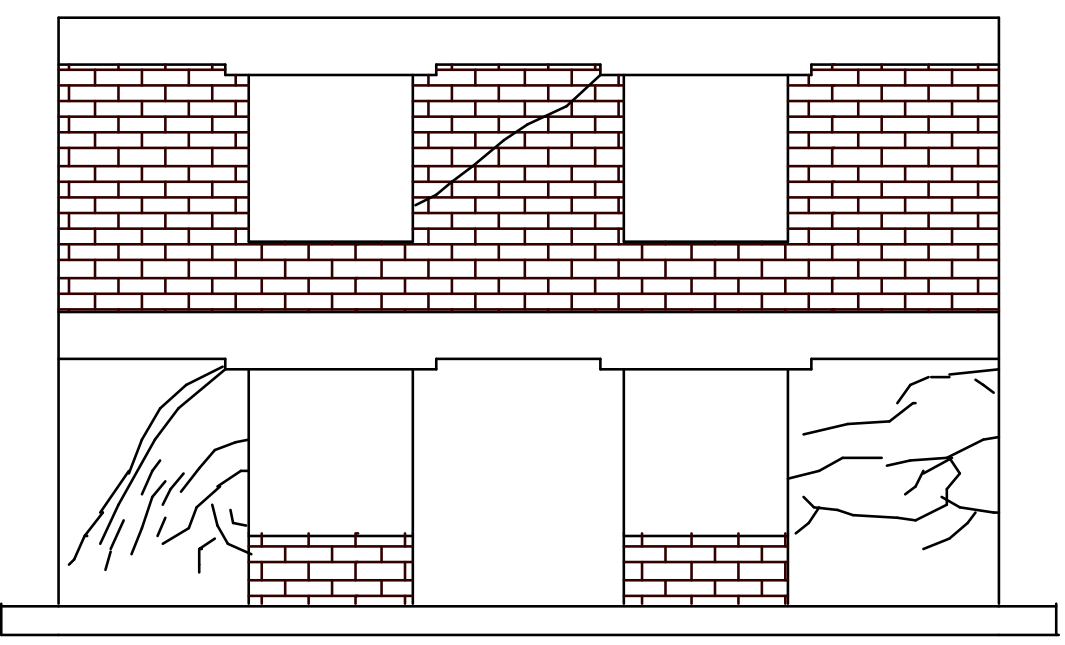

Figura 3.15 - Modelo ensaiado com reforço nas paredes 1 e 2 (barras diagonais) extraída de JABAROV et al. (1985).

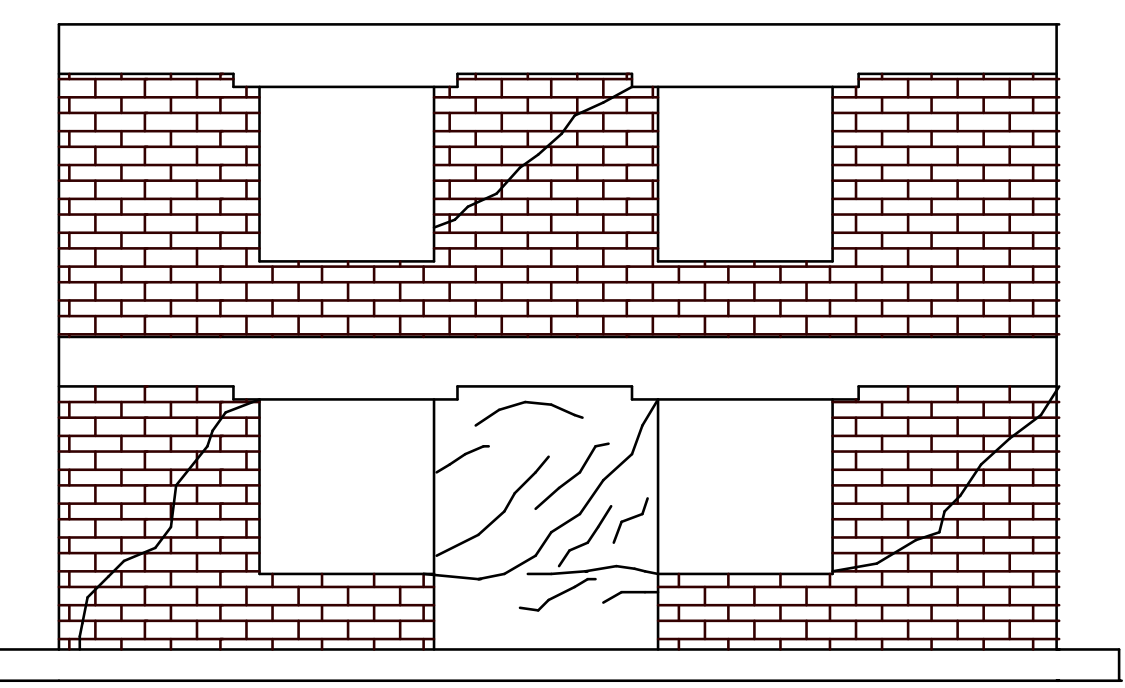

Figura 3.16 - Modelo ensaiado com reforço na parede 3 (telas soldadas) - extraída de JABAROV et al. (1985).

KAHN, L F. (1984) estudou a influência do revestimento armado no desempenho sísmico da alvenaria não-armada. Para isso, foram confeccionados 17 
painéis de alvenaria não-armada de tijolos maciços, dos quais 15 foram revestidos com argamassa projetada no traço de 1:3 (cimento:areia). O revestimento era aplicado mecanicamente (projetado) sobre as superfícies dos painéis e reforçados com telas soldadas. Conectores foram usados em alguns modelos revestidos intencionando-se obter um melhor comportamento alvenaria + revestimento.

O revestimento de cada painel foi reforçado com telas soldadas. Nove painéis de parede simples foram construídos para avaliar a aderência do revestimento na superfície da alvenaria seca, úmida e com uma camada de epoxy antes da concretagem. Seis painéis foram confeccionados com paredes duplas revestidas (com telas) e com conectores perfurados na alvenaria. Dois dos modelos de parede dupla foram revestidos sem a presença das telas soldadas. Foi também confeccionado um modelo de paredes simples e parede dupla para serem ensaiados sem revestimento.

O esquema do ensaio foi baseado na ASTM E-519 'Standard method of test for diagonal tension (shear) in masonry assemblages". A carga era aplicada ao longo de uma das diagonais. Depois que a carga máxima foi atingida, as deformações foram aumentando até a força alcançar a metade da máxima já obtida. Depois que a carga chegava a zero, o painel era rotacionado à $90^{\circ}$ e submetido a forças de compressão aplicada na outra diagonal.

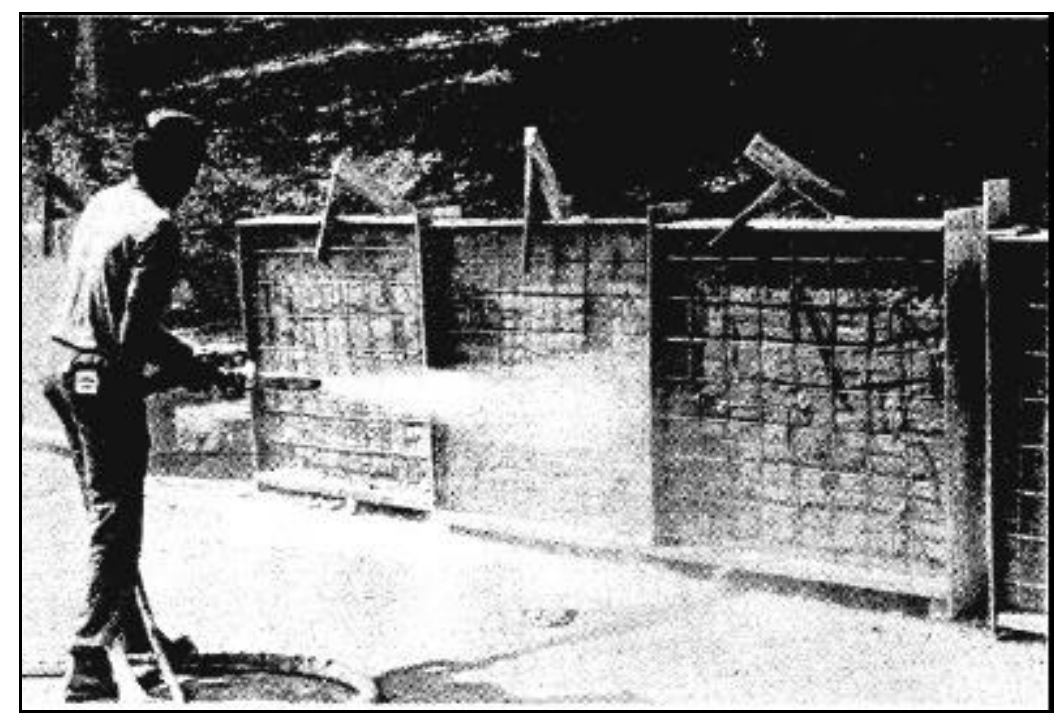

Figura 3.17 - Aplicação do revestimento nos painéis - extraída de KAHN, L F. (1984). 
Com os resultados obtidos, KAHN concluiu que a aplicação de um revestimento armado em uma parede de alvenaria não armada mostrou ser uma técnica eficaz no aumento da resistência ao cisalhamento e da capacidade de deformação.

Em todos os painéis, paredes simples ou paredes duplas, a alvenaria fissurou diagonalmente atravessando os tijolos.

Os conectores não melhoraram o comportamento do conjunto alvenaria + revestimento. Os painéis com revestimento armado apresentaram aumento significativo na resistência da parede depois da primeira fissura, como também aumentou-se a capacidade de deformação em relação aos painéis sem revestimento. Os painéis revestidos com argamassa projetada, mas sem telas, não apresentaram bom comportamento resistente pós-pico.

ALCOCER, S. M. et al. (1996) estudaram o efeito de revestimentos resistentes armados no desempenho de paredes de alvenaria de vedação submetidas a solicitações sísmicas. Telas soldadas foram usadas no revestimento, unidas à alvenaria de tijolos maciços por meio de pregos. Os modelos foram confeccionados em escala real e as paredes ensaiadas estavam confinadas por pilares e vigas de concreto. Foram construídos dois tipos de modelos para serem ensaiados.

Um dos modelo era de dois andares com dimensões de $500 \mathrm{~cm}$ de comprimento por $500 \mathrm{~cm}$ de altura. Os tijolos apresentaram resistência à compressão axial de 5,3 MPa e de compressão diagonal de 0,59 MPa. Este modelo foi danificado e depois recuperado preenchendo-se as fissuras com argamassa de cimento, substituindo-se os tijolos quebrados e aplicando-se um revestimento de argamassa no traço 1:4 (cimento areia) reforçado com telas. A argamassa de revestimento apresentou resistência de $10 \mathrm{MPa}$. Pregos de $40 \mathrm{~mm}$ de comprimento foram utilizados para fixação das telas (150 mm x $150 \mathrm{~mm}$ - $\$ 3,43 \mathrm{~mm}$ ), como também, tampas metálicas de garrafa que serviam de espaçadores entre a parede e a tela.

O outro modelo constituía-se de paredes com dimensões de $250 \mathrm{~cm}$ de comprimento por $250 \mathrm{~cm}$ de altura. Foram confeccionados cinco paredes que foram reforçadas com o mesmo tipo de revestimento utilizado no modelo de dois andares. Os tijolos tinham dimensões de 240 × 125 × $60 \mathrm{~mm}$. A argamassa de assentamento utilizada foi no traço de 1:4 com resistência de 9,8 MPa. Os tijolos apresentaram resistência à compressão axial de 5,2 $\mathrm{MPa}$ e compressão diagonal de 0,69 $\mathrm{MPa}$. 
Neste caso não foram usados espaçadores, sendo que a tela foi colocada diretamente na parede.

Nas paredes M1 e M2, pregos de $64 \mathrm{~cm}$ de comprimento foram espaçados de $300 \mathrm{~mm}$ em uma face da parede e $450 \mathrm{~mm}$ na outra face. A parede M1 dispunha de armadura horizontal conforme especificam as normas de execução de alvenaria do México (DDF 1995 - Departamento del Distrito Federal - Reglamento de construcciones para el Distrito Federal). As paredes M2 e M3 tinham aproximadamente duas e três vezes mais a quantidade de armadura horizontal que a M1 respectivamente. As resistências da argamassa de revestimento das paredes M1, M2 e M3 foram 12,2, 7,7 e 14,1 respectivamente. A parede MA não foi revestida, mas possuía a mesma quantidade de armadura horizontal que a parede M1, enquanto que a parede M0 foi revestida mas não possuía armadura horizontal.

Depois de realizados os ensaios foi verificado que esse método de reabilitação aumenta a resistência sísmica de paredes de alvenaria. Os danos causados em todas as paredes foi caracterizado por fissuras inclinadas nas superfícies dos painéis. A parede M0 (sem armadura horizontal) apresentou uma concentração de fissuras ao longo da sua diagonal, sendo que as demais paredes apresentaram uma distribuição mais uniforme das fissuras.

No modelo de dois andares a maioria dos danos ocorreu no primeiro andar. As fissuras diagonais neste andar foram mais concentradas quando a alvenaria não estava revestida e foram amplamente distribuídas quando a superfície foi revestida. O mesmo fenômeno aconteceu com as demais paredes. A parede M1 apresentou fissuras inclinadas bem distribuídas e rompeu por cisalhamento. A parede M2 rompeu prematuramente devido a fissuras e esmagamento do revestimento na parte central do modelo ( a resistência da argamassa de revestimento era baixa). A parede M3 apresentou fissuras também bem distribuídas e pequenas fissuras horizontais nas extremidade. Nas figuras ${ }^{3}$ apresentadas a seguir estão esquematizadas as configurações de fissura dos modelos ensaiados.

\footnotetext{
${ }^{3}$ Figuras extraídas de ALCOCER, S. M. et al. (1996).
} 


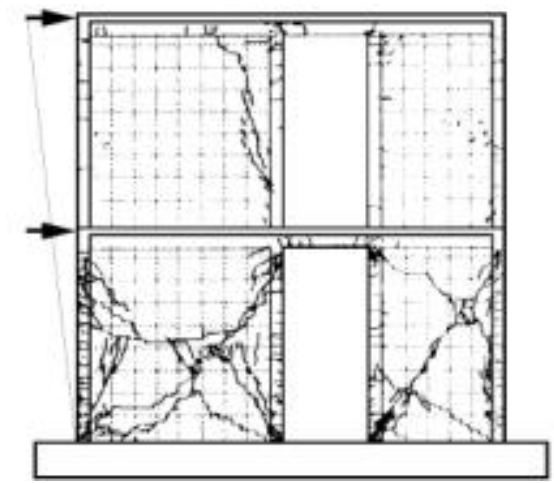

Figura 3.18 - Modelo sem revestimento. Figura 3.19 - Modelo reabilitado.

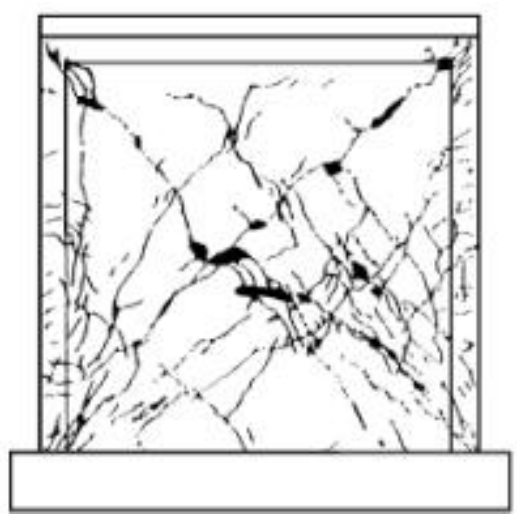

Figura 3.20 - Modelo M0.

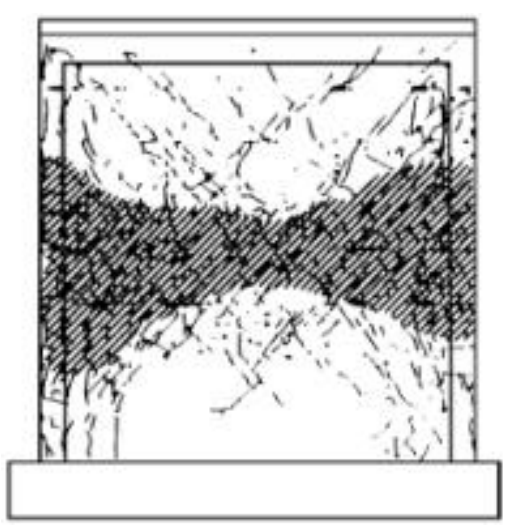

Figura 3.22 - Modelo M2.
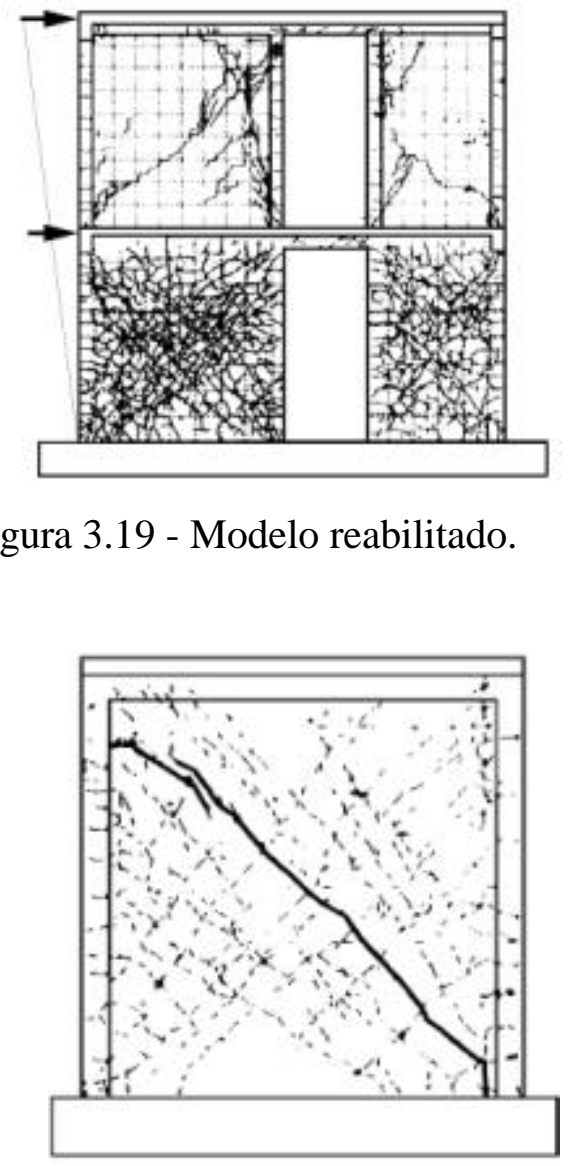

Figura 3.21 - Modelo M1.

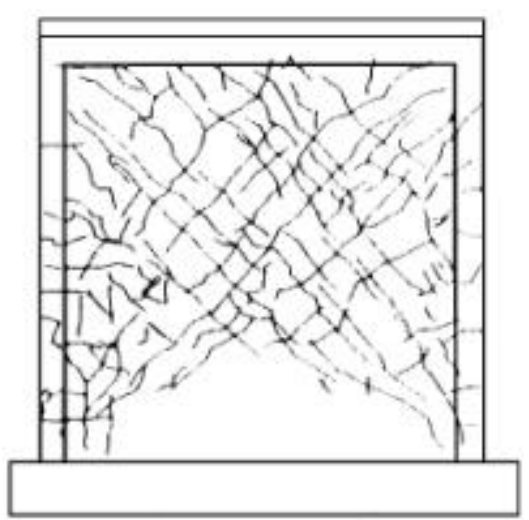

Figura 3.23 - Modelo M3.

Concluiu-se que a técnica de reabilitação proporcionou às estruturas analisadas um significativo aumento na resistência ao cisalhamento, na rigidez e na capacidade de deformação. Baseado nas observações realizadas durante os ensaios e análise dos resultados pode-se dizer que: as fissuras e o mecanismo de ruptura dos modelos eram 
devidos às deformações por cisalhamento; os modelos com revestimentos reforçados com telas apresentaram uma distribuição uniforme de fissuras diagonais, quando comparados com os modelos sem revestimento; a rigidez inicial dos modelos reabilitados foi de $2 / 3$ do valor da parede original. A rigidez inicial das paredes revestidas sem dano algum não foi afetada pela quantidade de armadura horizontal.

EHSANI \& SAADATMANESH (1996) estudaram a reabilitação de paredes de alvenaria não-armada com aplicação de camadas de compósitos de fibras ${ }^{4}$, considerando-as como revestimento e verificando sua influência no aumento da resistência.

Antes da aplicação do método de reabilitação proposto é necessário aplicar jatos de areia na superfície da parede, para remover partículas soltas, substituir as unidades danificadas e preencher as fissuras com argamassa. Depois, camadas telas de fibras de aproximadamente $90 \mathrm{~cm}$ de largura são aplicadas na parede em tiras verticais e pressionadas sobre o epoxy aplicado na superfície da parede. Depois disso, outra camada de epoxy é aplicada sobre as tiras de telas de fibras e, finalmente, a parede é coberta com uma camada protetora de raios ultravioleta. A aplicação dessa técnica está demonstrada na Figura 3.24.

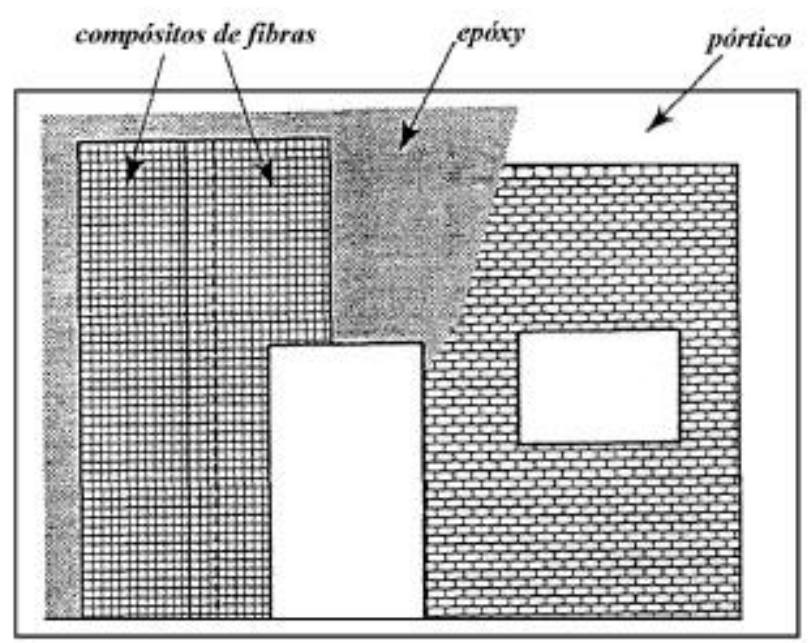

Figura 3.24 - Exemplo de aplicação dos compósitos de fibras - extraída de EHSANI \& SAADATMANESH (1996).

\footnotetext{
${ }^{4}$ Os compósitos de fibras aqui mencionados são em formato de telas.
} 
O comportamento da parede de alvenaria não-armada à flexão foi examinado por meio de ensaios de vigas. As vigas eram de tijolos de barro maciços com dimensões de $81 / 2$ " de altura, 4" de espessura e 57" de comprimento.

Dois tipos de epoxy foram empregados. O primeiro era composto por dois componente à base de epoxy com consistência similar à da pasta de cimento. $\mathrm{O}$ segundo tipo era também composto por dois componentes à base de epoxy, mas com viscosidade mais baixa que o primeiro.

Dois tipos de argamassa de assentamento foram usados, os tipos $\mathrm{M}$ e $\mathrm{M}^{*}$ (ASTM C-270). A primeira no traço de 1:1/4:3 (cimento:cal:areia) com resistência a compressão de $32 \mathrm{MPa}$ e, a segunda no traço de 1:1/4:5 (cimento:cal:areia) com resistência à compressão de $28 \mathrm{MPa}$. Três tipos de telas (vidro, carbono e aço) com diferentes resistências foram usadas para verificação do modo de ruptura. O gráfico tensão-deformação dos três componentes utilizados para comparação está demonstrado a seguir.

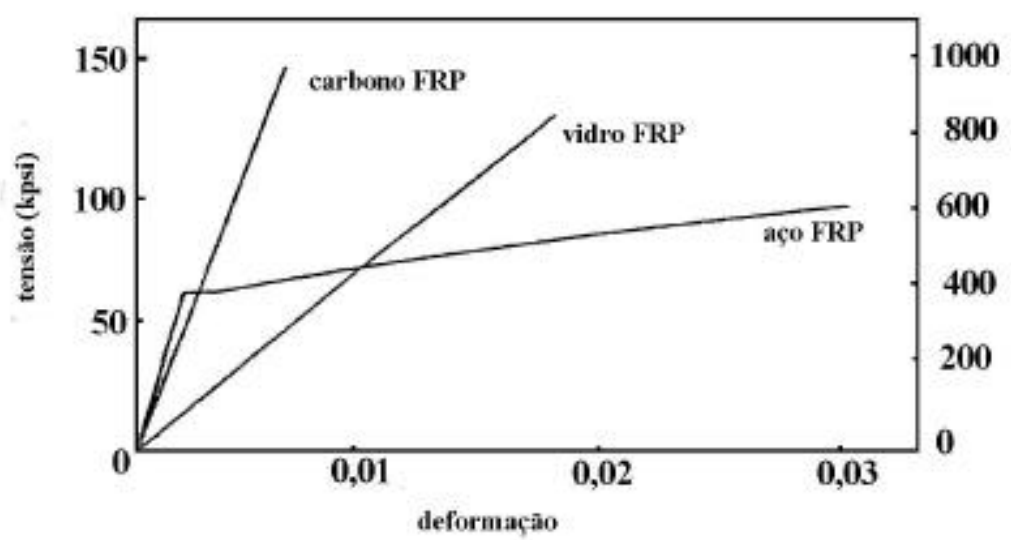

Figura 3.25 - Gráfico tensão - deformação dos compósitos analisados - EHSANI \& SAADATMANESH (1996).

Ensaios de cisalhamento direto foram realizados com os mesmos tipos de fibras. Os modelos ensaiados foram confeccionados com três tijolos cerâmicos revestidos com a aplicação das camadas de fibras. A dimensão dos modelos foram de 4,5" de largura por 8" de comprimento. 
Com os resultados obtidos observou-se que a resistência à flexão, cisalhamento e a ductilidade aumentam significadamente os seus valores com o uso de compósitos de fibras.

As vigas reforçadas e ensaiadas à flexão resistiram a cargas de 24 vezes o valor do seu peso próprio. Os modelos ensaiados por cisalhamento direto resistiram a forças elevadas e romperam apresentando uma ductilidade satisfatória. O modo de ruptura foi determinado pela resistência dos compósitos, ou seja, os compósitos de fibras menos resistentes rompiam antes dos tijolos, enquanto que os mais resistentes mantinham-se íntegros até a alvenaria alcançar sua capacidade resistente.

Com todo esse embasamento teórico adquirido conclui-se que a técnica de aplicação de revestimentos resistentes é eficaz na recuperação e reforço de estruturas de alvenaria. Todavia, ressalta-se a necessidade de mais pesquisas nessa área para melhor esclarecimento do uso da técnica, como o estabelecimento de métodos de dimensionamento do reforço, a indicação de situações típicas em que ela pode ser usada, modo de aplicação, vantagens e desvantagens, como também os procedimentos para quantificar o acréscimo da resistência em relação à espessura do revestimento. 


\section{METODOLOGIA APLICADA PARA O DESENVOLVIMENTO DA PESQUISA}

Embora inúmeras pesquisas estejam voltadas ao estudo das técnicas de reabilitação de estruturas danificadas, ainda não existe um conjunto suficiente de metodologias específicas de análise do comportamento estrutural da peça reabilitada nem diretrizes que orientem o projetista durante o processo de redimensionamento e reprojeto.

Portanto, apesar de várias obras terem sido reabilitadas com sucesso, ainda há vários fatores que merecem ser investigados para avaliar melhor o comportamento da estrutura reabilitada. O melhor desenvolvimento e a exploração de novas possibilidades de uma técnica já aplicada com sucesso em alguns casos específicos também contribuirá ao domínio completo desse campo de atividade.

Sendo assim, o diagnóstico das causas e dos mecanismos de evolução dessas falhas, as formas de manifestação e as medidas de prevenção, principalmente as de recuperação, vêm sendo estudados por pesquisadores de todo o mundo, de forma a acrescentar técnicas adequadas para execução de reparos ou reforços nas estruturas.

A técnica de reforço em estudo consiste na aplicação de revestimentos resistentes de argamassa armada em paredes de alvenaria, objetivando estudar o comportamento conjunto tipo sanduíche dos materiais (considerando a alvenaria como núcleo), desenvolvendo métodos de análise teórica e experimental, por meio de estudos de caso de paredes de alvenaria com e sem revestimento.

A metodologia aplicada para verificação da validade da técnica foi subdividida em duas partes: uma análise experimental - onde foram realizados ensaios físicos de paredes de alvenaria submetidas a diferentes solicitações - e uma análise teórica que consistiu da aplicação de procedimentos analíticos para avaliar o desempenho dessas 
paredes, em alguns casos complementada por uma análise numérica. A análise numérica, em geral, teve o objetivo tão somente de constatar a distribuição de tensões e a ordem de grandeza dos esforços que surgem em paredes de alvenaria quando submetidas a solicitações iguais às estudadas na análise experimental.

\subsection{Análise experimental}

\subsubsection{Ensaios de compressão axial}

A análise experimental teve início com os ensaios de compressão axial cuja metodologia foi baseada na NBR-8949 - Paredes de alvenaria estrutural: ensaio à compressão simples. Os blocos e os prismas (com e sem revestimento) foram ensaiados de acordo com a NBR 7186 - Bloco Vazado de concreto simples para alvenaria com função estrutural e a NBR 8215 - Prismas de blocos de concreto para alvenaria estrutural - preparo e ensaio à compressão, respectivamente.

Inicialmente, realizou-se uma série de ensaios-piloto, de caráter exploratório, que serviria de orientação para os demais ensaios. Neste estudo preliminar foram ensaiadas 3 paredes de alvenaria estrutural à compressão simples, nas seguintes situações: parede sem revestimento (situação 1), parede não danificada com revestimento de argamassa armada (situação 2) e parede danificada e recuperada com revestimento de argamassa armada (situação 3).

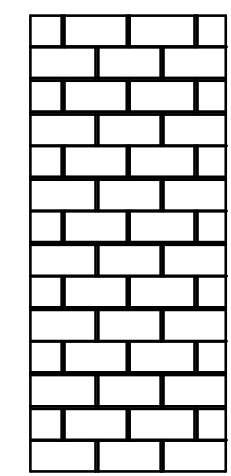

Figura 4.1 - Situação 1

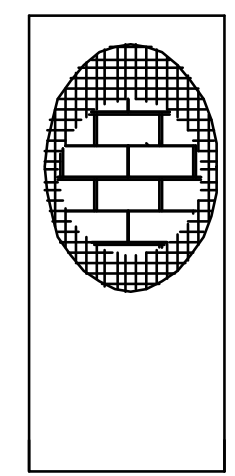

Figura 4.2 - Situação 2

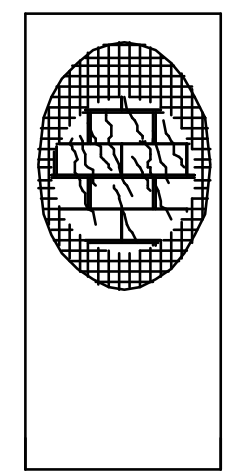

Figura 4.3 - Situação 3

As paredes foram confeccionadas com blocos vazados de concreto, com resistência nominal de 4,5 $\mathrm{MPa}$ e dimensões nominais de 40 x 20 x $15 \mathrm{~cm}$. A argamassa de assentamento utilizada foi de cimento, cal e areia no traço de 1:0,5:3 (em volume). 
O revestimento resistente aplicado, tanto na situação 2 como na situação 3 , foi de argamassa de cimento e areia de traço 1:1,5;1,5 (cimento, areia fina; areia grossa, em volume), aplicada manualmente. O revestimento, com espessura total de $1,5 \mathrm{~cm}$, foi armado com uma tela soldada (EQ - 120) de fios de 2,77 mm de aço CA-60B, espaçados $50 \mathrm{~mm}$. A tela de aço foi posicionada junto às faces da parede, sendo fixada por meio de fios de arame recozido, que foram passados por furos realizados nos blocos com brocas de vídia.

Os modelos tinham dimensões de 120 x $260 \mathrm{~cm}$ (largura x altura). Foram moldados dois corpos-de-prova da argamassa de assentamento a cada quarto da parede. As paredes foram ensaiadas aplicando-se cargas distribuídas por meio de quatro macacos hidráulicos uniformemente espaçados com capacidade individual de $250 \mathrm{kN}$. Os encurtamentos longitudinais e a flecha lateral foram registrados no final do período de cada incremento de carga, que corresponde a $10 \%$ do valor da carga de ruptura provável.

O posicionamento dos transdutores de medição de deslocamento está esquematizado na Figura 4.4. Na Tabela 4.1 apresentam-se os principais resultados obtidos nos ensaios das paredes e dos corpos-de-prova da argamassa de assentamento e da argamassa de revestimento.

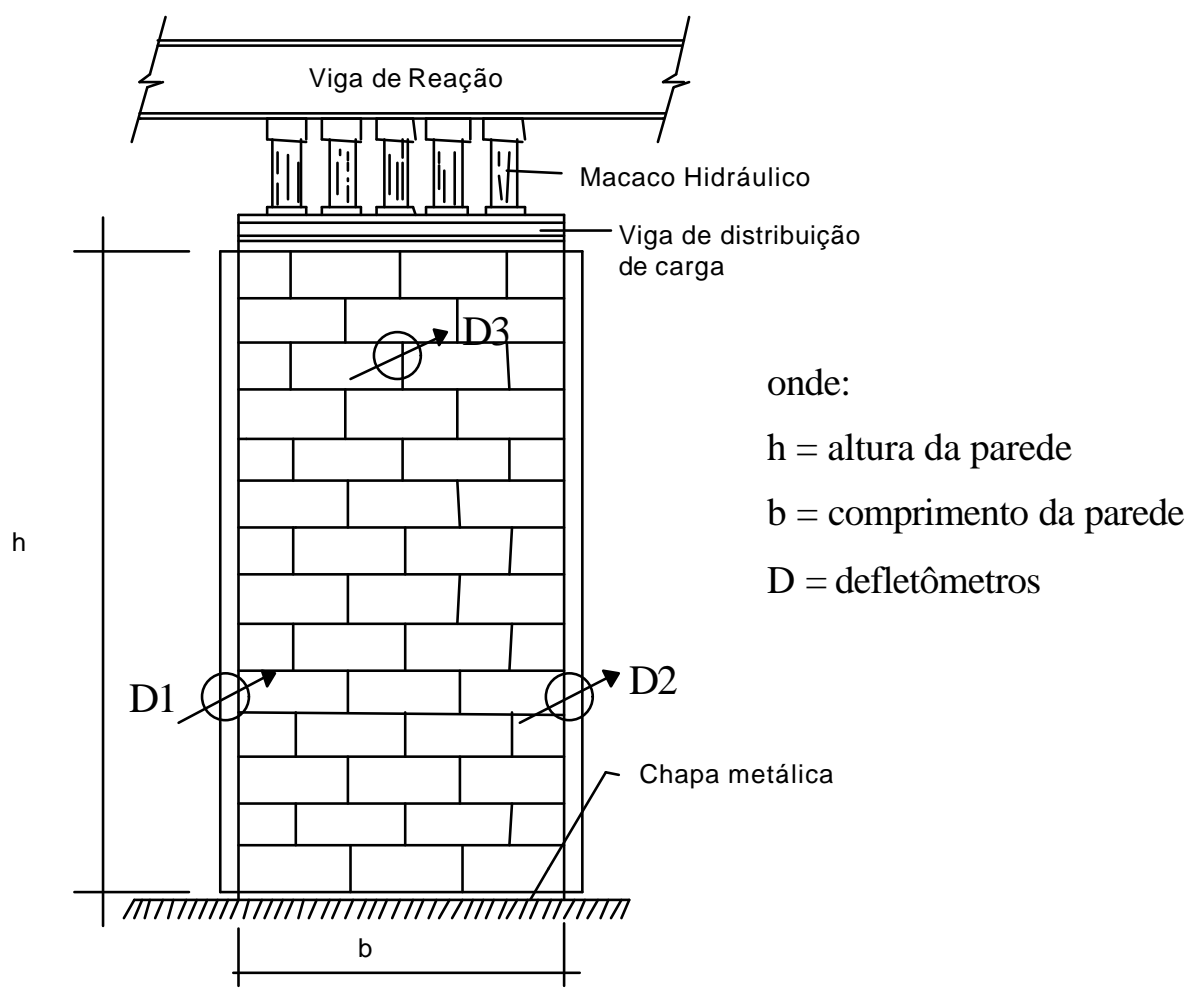

Figura 4.4 - Esquema do ensaio à compressão simples de paredes de alvenaria. 


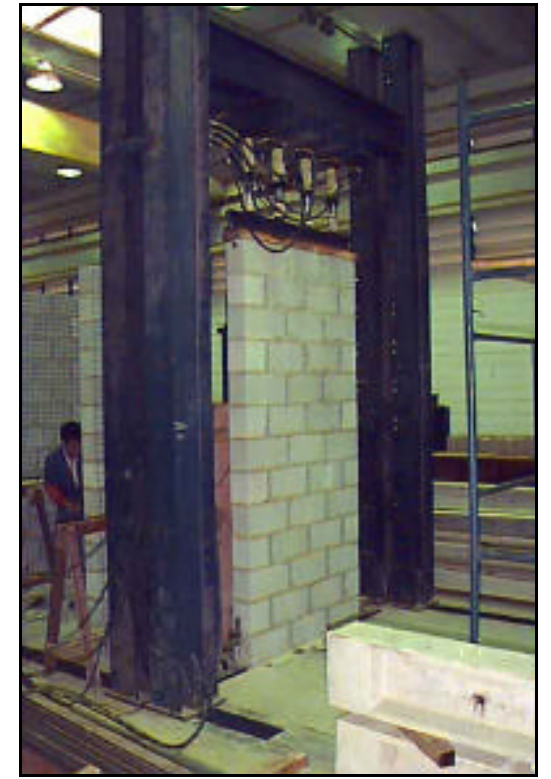

Figura 4.5 - Vista do ensaio.

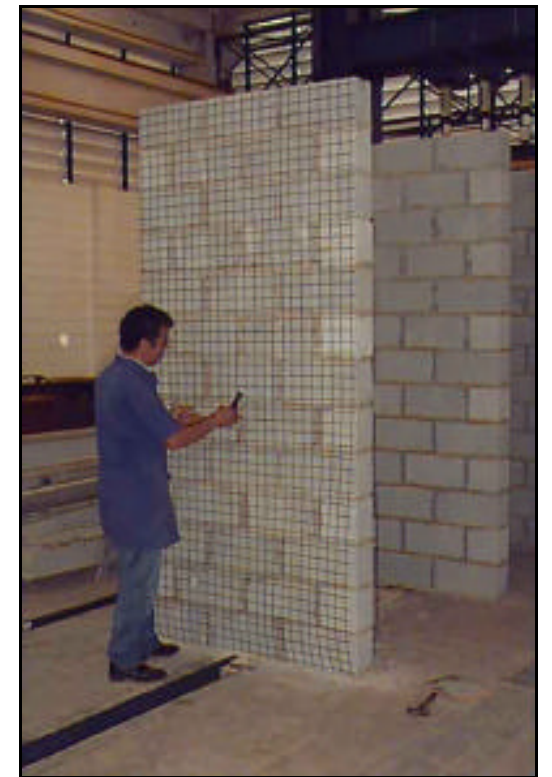

Figura 4.6 - Colocação das telas.

Tabela 4.1 - Resumo dos resultados dos ensaios.

\begin{tabular}{|c|c|c|c|c|c|}
\hline Parede & $\begin{array}{l}\text { Condição de } \\
\text { revestimento }\end{array}$ & $\begin{array}{c}\mathrm{f}_{\text {arg }} \\
(\mathrm{MPa}) \\
\end{array}$ & $\begin{array}{c}\mathrm{f}_{\mathrm{cr}} \\
(\mathrm{MPa}) \\
\end{array}$ & $\begin{array}{c}\mathrm{f}^{\prime} \mathrm{p} \\
(\mathrm{MPa}) \\
\end{array}$ & $\begin{array}{l}\mathrm{F}_{\max } \\
(\mathrm{kN}) \\
\end{array}$ \\
\hline $\mathrm{P} 1$ & sem revestimento & 29 & - & 4,2 & 242 \\
\hline $\mathrm{P} 2$ & com revestimento & 33 & 8 & 5,3 & 418 \\
\hline P3 & sem revestimento & 27 & - & 4,1 & 361 \\
\hline $\mathrm{P} 1 \mathrm{r}$ & $\begin{array}{l}\text { fissurada e } \\
\text { recuperada com } \\
\text { revestimento }\end{array}$ & 38 & 11 & 5,4 & $900 *$ \\
\hline \multicolumn{6}{|c|}{$\begin{array}{l}\text { Observações: } \\
\mathrm{f}_{\text {arg }} \text { - resistência da argamassa de assentamento } \\
\mathrm{f}_{\mathrm{cr}} \text { - resistência da argamassa de revestimento } \\
\mathrm{f}_{\mathrm{p}} \text { - resistência do prisma } \\
\mathrm{F}_{\max } \text { - força máxima aplicada na parede durante o ensaio } \\
* \text { Ensaio interrompido sem ruptura da parede }\end{array}$} \\
\hline
\end{tabular}

Como se pode notar, a resistência da argamassa de assentamento foi maior do que a usualmente adotada na prática. Isto ocorreu porque se utilizou cimento de alta resistência inicial para que os ensaios fossem realizados a curto prazo, mas o resultado foi muito superior ao esperado.

Por outro lado, pode-se considerar que a resistência da argamassa empregada no revestimento foi muito baixa. Neste caso, o emprego de uma argamassa pouco 
resistente foi proposital, pois esperava-se uma contribuição significativa do revestimento na resistência da parede, e isso poderia fazer que a capacidade de carga do pórtico de reação utilizado no ensaio fosse atingida sem alcançar a ruptura da parede. De fato, mesmo com o revestimento de argamassa pobre, o ensaio da parede P1r na situação 3 (parede recuperada), a capacidade do pórtico de reação foi atingida sem ruptura da parede.

A parede P1 (sem revestimento) foi ensaiada na situação 1, com 5 dias de idade, atingindo a ruptura com a força máxima de $242 \mathrm{kN}$. Observou-se o aparecimento de fissuras no plano médio da parede, inicialmente junto à parte superior, e depois também nas juntas dos blocos na região superior.

A parede P3 (sem revestimento) foi ensaiada na situação 1, com 7 dias de idade, atingindo a ruptura com a força máxima de $361 \mathrm{kN}$, quando se observou uma deformação lateral excessiva, acusada pelo transdutor de deslocamento posicionado para medir a flecha lateral.

A parede P2 foi ensaiada na situação 2 (parede revestida, sem quaisquer danos prévios), com 16 dias de idade relativa ao assentamento dos blocos e 6 dias de idade relativa ao revestimento. A ruptura foi atingida com a força máxima de $418 \mathrm{kN}$, maior que a da parede P1, com fissuras que se estenderam no plano médio a partir da parte superior. Todavia, suspeita-se que o fendilhamento excessivo decorreu da deformação transversal exagerada de uma prancha de madeira (que chegou a partirse) colocada entre o perfil de aço e a parede, provocando uma ruptura prematura.

A parede P1r representa a situação 3, uma vez que a parede P1, depois de ensaiada até a ruptura, foi revestida com uma camada de argamassa armada com uma tela soldada EQ-120. A idade da parede era de 26 dias, e a do revestimento, de 10 dias. A força máxima aplicada durante o ensaio foi de $900 \mathrm{kN}$, o qual foi interrompido por ter-se atingido a capacidade máxima do pórtico de reação.

Em nenhuma das paredes revestidas chegou-se a observar o aparecimento de fissuras nos revestimentos.

No gráfico da Fig. 4.1 mostra-se o diagrama força $\mathrm{x}$ encurtamento médio das paredes relativo aos 4 ensaios realizados. 


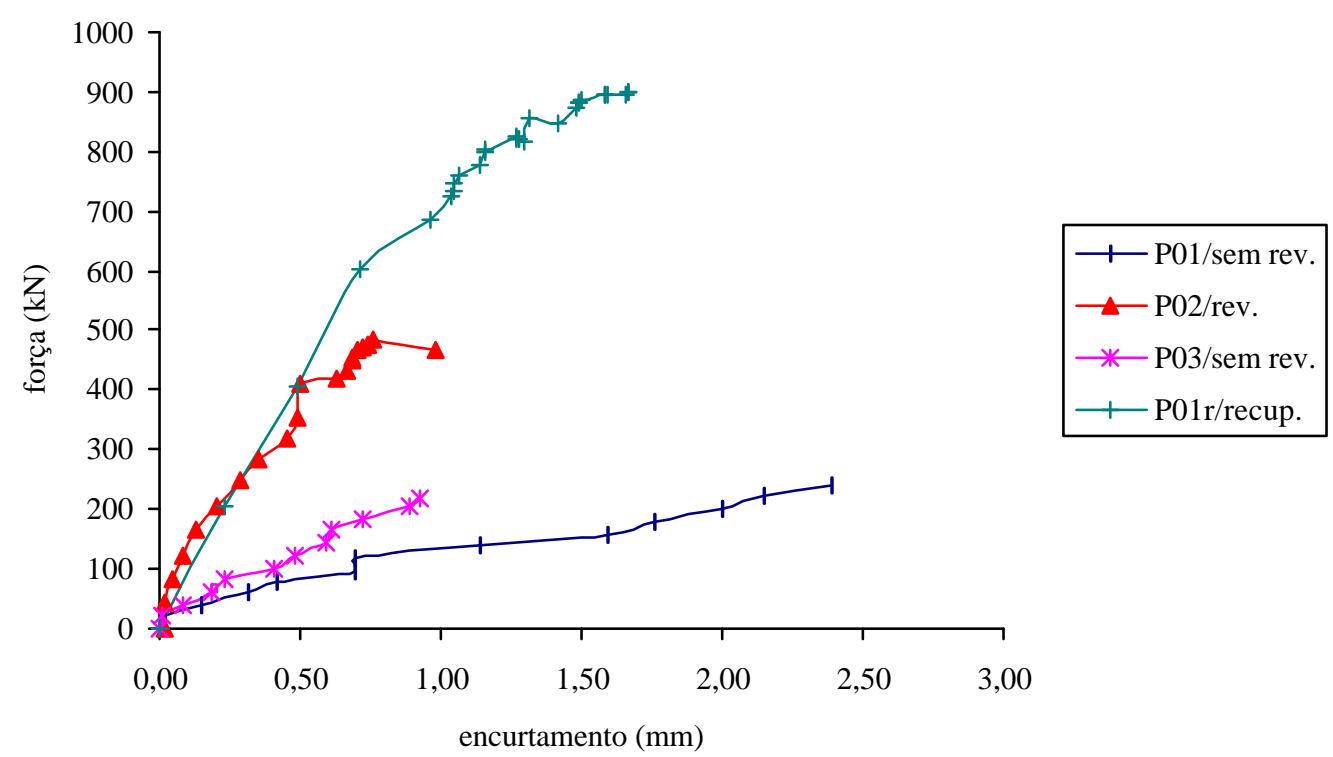

Figura 4.7 - Diagramas Força x Encurtamento médio da parede.

Pelos resultados apresentados na Tabela 4.1 e na Figura 4.7, os seguintes aspectos podem ser destacados:

a) a aplicação de um revestimento armado aumenta a resistência à compressão da parede, podendo ser utilizado tanto como um recurso de projeto ou de reabilitação;

b) a aplicação do revestimento aumenta a rigidez da parede, tornando-a menos deformável por compressão;

c) os resultados particulares desta série-piloto de ensaios mostraram que uma parede, como a parede P1r, mesmo recuperada com um revestimento de argamassa de baixa resistência à compressão, teve sua resistência multiplicada por 3,7 sem ocorrência de fissuras no revestimento; essa mesma parede teve sua rigidez aumentada, alcançando uma rigidez similar à da parede revestida sem danos previamente introduzidos;

d) embora não tenha havido condições para uma avaliação da ductilidade da parede, pode-se dizer que a evolução dos encurtamentos observados na parede P2 apontam para a melhoria da ductilidade, principalmente quando 
houver condições mais adequadas para a ação da armadura distribuída de telas de aço e uma argamassa de revestimento de melhor qualidade.

Diante desses resultados constatou-se que a exploração da técnica descrita possibilita o desenvolvimento de métodos de reabilitação que se incorporem ao conhecimento empírico existente, especialmente no que se refere à utilização de revestimentos resistentes de argamassa armada.

Foi realizada ainda uma segunda série-piloto de ensaios, em condições semelhantes, utilizando-se vários tipos de revestimentos. Nesta série foram construídos 16 modelos com dimensões de $80 \times 160 \mathrm{~cm}$ (Figura 4.8). Em todas as paredes revestidas a espessura do revestimento era de $1,5 \mathrm{~cm}$. Os revestimentos utilizados foram:

a) argamassa fraca - paredes revestidas com argamassa de traço 1:3,5:10. A denominação "fraca" foi dada considerando-se que o módulo de elasticidade da argamassa de revestimento é menor que o módulo de elasticidade da parede sem revestimento (bloco + argamassa).

$$
\mathrm{E}_{\mathrm{pa}}=9.365 \mathrm{MPa} \quad \mathrm{E}_{\text {arg.fr. }}=4.300 \mathrm{MPa}
$$

b) argamass forte - paredes revestidas com argamassa de traço 1:3. A denominação "forte" foi dada considerando-se que o módulo de elasticidade da argamassa de revestimento é maior que o módulo de elasticidade da parede sem revestimento (bloco + argamassa).

$$
\mathrm{E}_{\mathrm{pa}}=9.365 \mathrm{MPa} \quad \mathrm{E}_{\text {arg.f }}=21.710 \mathrm{MPa}
$$

c) telas soldadas - paredes revestidas com argamassa "forte" + telas soldadas. As telas utilizadas eram telas de aço soldadas de fios de $2,77 \mathrm{~mm}$, espaçados $50 \mathrm{~mm}$, as quais foram posicionadas junto às faces da parede. A relação água/cimento adotada na argamassa forte foi de 0,45 .

d) telas soldadas + conectores 1 - paredes revestidas com argamassa "forte" + telas soldadas (nas faces e também e nas juntas da parede). As telas utilizadas eram telas de aço soldadas de fios de 2,77 mm de aço CA-60B, espaçados $50 \mathrm{~mm}$, as quais foram posicionadas junto às faces da parede $\mathrm{e}$ nas juntas horizontais de argamassa. As telas posicionadas nas camadas 
horizontais de argamassa serviriam como conectores (para evitar o destacamento das placas, como foi observado nos ensaios anteriores) e para conter as fissuras nos septos dos blocos provocadas pela expansão da argamassa de assentamento. A relação água/cimento adotada na argamassa forte foi de 0,45 .

e) telas soldadas + conectores 2 - paredes revestidas com argamassa "forte" + telas soldadas + conectores. ). As telas utilizadas eram telas de aço soldadas de fios de 2,77 mm de aço CA-60B, espaçados $50 \mathrm{~mm}$, as quais foram posicionadas junto às faces da parede e fixadas por "ganchos" (fios de aço de $5 \mathrm{~mm}$ de aço CA-60B). Os conectores eram constituídos por tubos de PVC que traspassavam a espessura dos blocos, depois preenchidos com a mesma argamassa do revestimento e com os fios de $5 \mathrm{~mm}$ para evitar o destacamento das placas. A relação água/cimento adotada na argamassa forte foi de 0,45 .

f) fibras de polipropileno - paredes revestidas com argamassa "fraca" + fibras de polipropileno. As fibras utilizadas eram fibriladas da marca HAREX, em volume de $0,25 \%$.

g) fibras de aço - paredes revestidas com argamassa "forte" + fibras de aço. As fibras utilizadas no volume de $0,50 \%$ eram retas, com extremidades em gancho (RC 65/30 BN), marca DRAMIX, comprimento igual a $30 \mathrm{~mm}$ e $\phi_{\mathrm{t}}$ $=0,45 \mathrm{~mm}$.

Ressalta-se que essa série foi interrompida depois de ensaiadas as paredes P01, P04, P05 (sem revestimento) e P12 (revestida com argamassa "fraca"), quando se percebeu que apesar da utilização de modelos menores a capacidade de carga do pórtico de reação utilizado (instalado na laje de reação do LE-EESC) foi praticamente atingida, impossibilitando os ensaios nas demais paredes revestidas, que provavelmente romperiam com cargas bem mais elevadas que as primeiras o que levou à interrupção dos ensaios até a instalação de uma nova Máquina Universal de Ensaios, recém adquirida. Depois de instalado o equipamento hidráulico servocontrolado, e que permite a realização dos ensaios com deformação controlada com 
capacidade de até $3000 \mathrm{kN}$, a série-piloto foi reiniciada, ensaiando-se as demais paredes.

Com isso, o cronograma de ensaios dos modelos foi prejudicado e as paredes foram construídas sem um dispositivo adequado para transporte. Além disso, os resultados mostraram-se contraditórios e de grande variabilidade, o que motivou uma revisão da metodologia de ensaio.
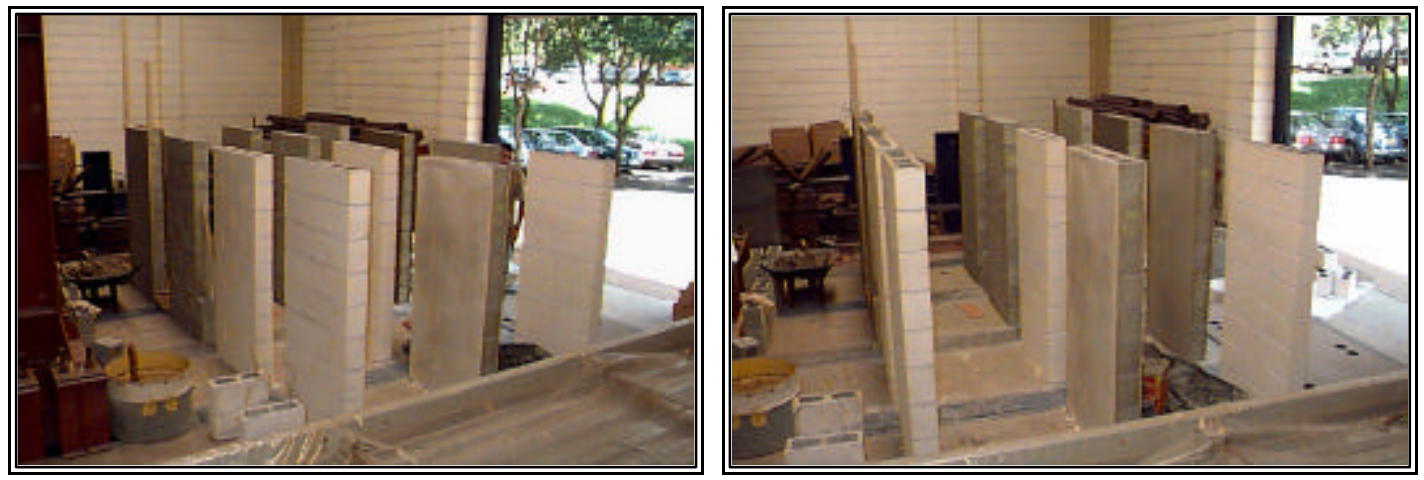

Figura 4.8 - Vista dos modelos da $2^{\mathrm{a}}$ série de ensaios.

Com o término da segunda série de ensaios-piloto, foi possível definir alguns parâmetros para os ensaios seguintes de compressão axial. Tentou-se nessa fase eliminar o maior número de variáveis para se obter resultados mais precisos e consequentemente se alcançar uma análise mais exata. A primeira providência tomada foi a redução da dimensão dos modelos. Essa decisão deve-se ao fato de que na segunda série de ensaios-piloto a variabilidade dos resultados foi elevada, devido em grande parte a excentricidades acidentais na aplicação do carregamento. Outro fator também levado em consideração foi a deficiência de aderência entre o revestimento e o núcleo. A parede revestida funciona como uma camisa, mas o efeito do confinamento não existe.

Sendo assim, a série final de ensaios foi programada. Os corpos-de-prova tinham dimensões de 39 × $81 \mathrm{~cm}$ com camada de argamassa no topo e na base do modelo para melhor regularização. Foram idealizados gabaritos de chapas de aço para confecção dos corpos-de-prova objetivando uma maior precisão durante o assentamento.

Apesar do procedimento de ensaio ter sido baseado na NB 8949 algumas modificações foram feitas como: a colocação de chapas de aço nas extremidades da 
parede para uma distribuição mais eficiente do carregamento, sem uso de placas de madeira ou papelão, e a colocação de relógios comparadores em torno de toda a parede para registro dos encurtamentos e verificação da excentricidade da carga aplicada. O gabarito e a situação de medição estão esquematizados a seguir.
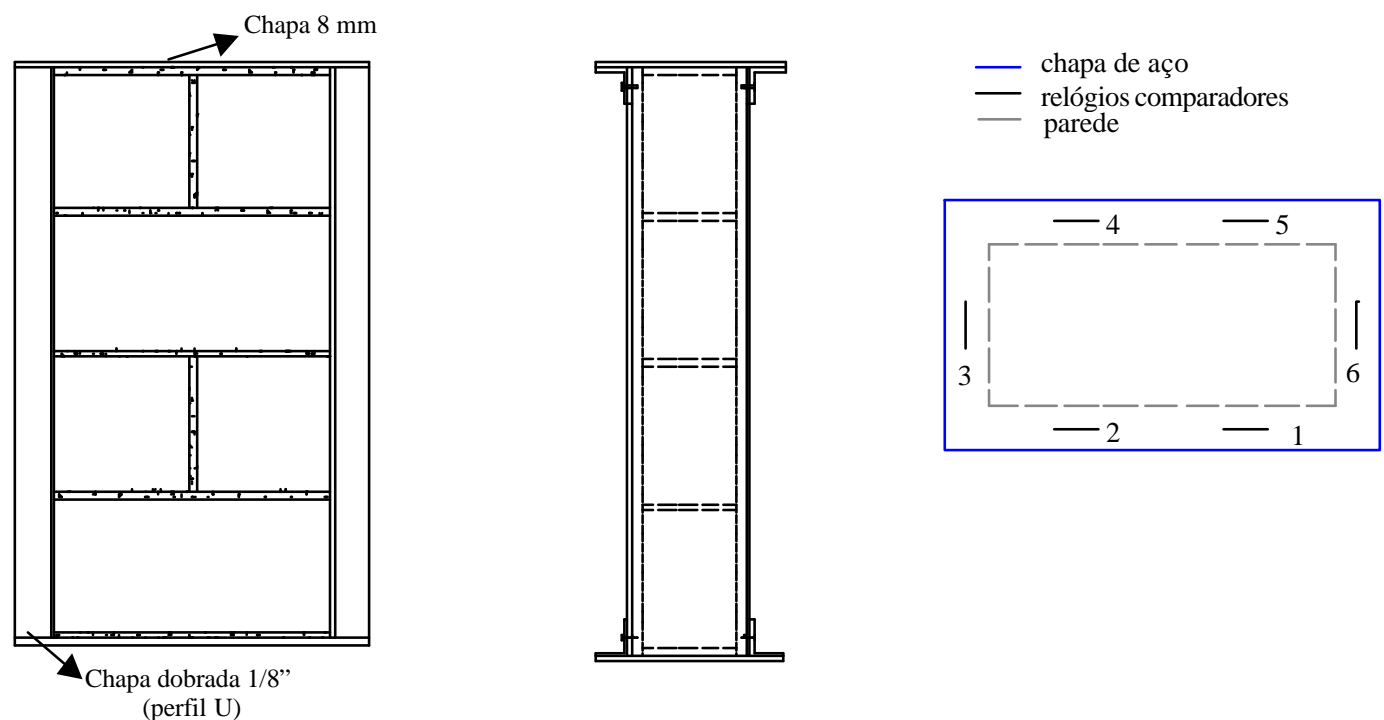

Figura 4.9 - vista de frente. Figura 4.10 - vista lateral. Figura 4.11 - vista de cima.

Cada corpo-de-prova (paredinha) foi executado, transportado e ensaiado da seguinte maneira:

a) Montava-se parcialmente o gabarito, unindo a chapa de aço da base com os perfis laterais de chapa dobrada, por meio de parafusos;

b) Aplicava-se uma camada de argamassa de assentamento sobre a chapa da base, a partir da qual assentava-se os blocos de concreto, tomando-se como guia os perfis laterais do gabarito;

c) No topo da paredinha aplicava-se uma última camada de argamassa de assentamento, ajustando-se logo em seguida a chapa de aço de topo, que também era aparafusada nos perfis laterais, fechando-se desta forma o gabarito;

d) Após o período de cura ao ar, o conjunto todo (gabarito+paredinha) eram transportado para a Máquina Universal de Ensaios;

e) Uma vez posicionada a paredinha para o ensaio à compressão axial, os perfis laterais eram removidos, mantendo-se as chapas de aço de topo e de base intocadas; 
f) O ensaio das paredinhas à compressão axial era realizado com dois ciclos de pré-carregamento, durante os quais se procurava observar a existência de excentricidades significativas;

g) Em seguida era realizado o carregamento até o colapso, programando-se a Máquina Universal para incremento de deslocamento do pistão à razão de $0,005 \mathrm{~mm} / \mathrm{s}$ (ensaio com deformação controlada).

Antes de ser realizada a série final foi ensaiado um modelo como referência, para testar tanto o gabarito, quanto o procedimento de ensaio programado. Ilustrações do ensaio realizado são apresentadas nas figuras a seguir.

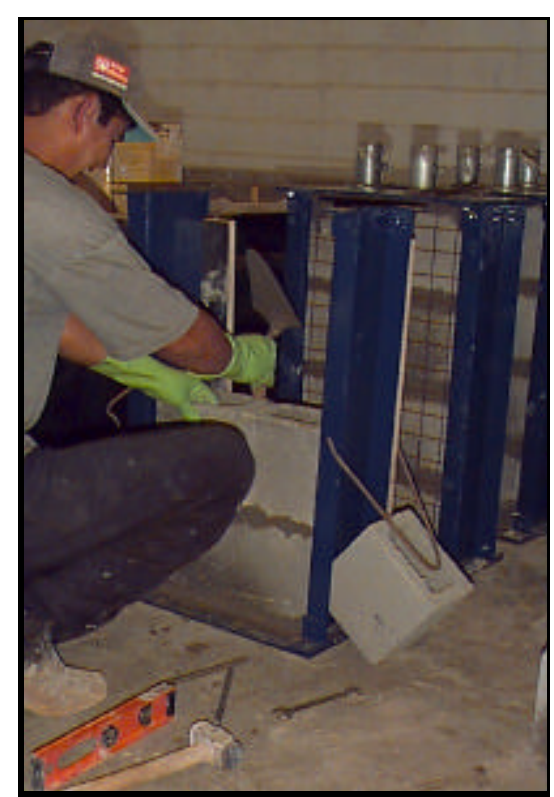

Figura 4.12 - Execução das paredes com o gabarito.

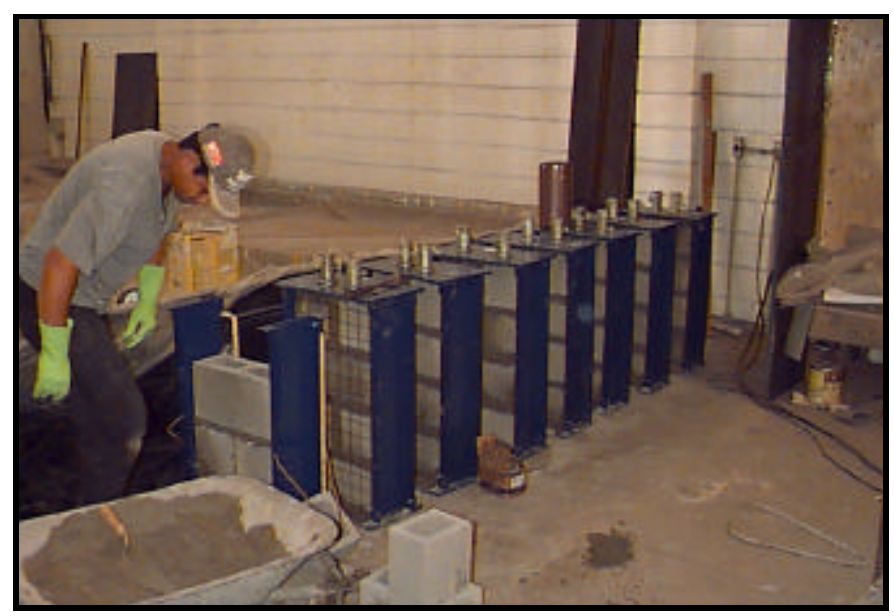

Figura 4.13 - Vista das paredinhas sendo confeccionadas. 

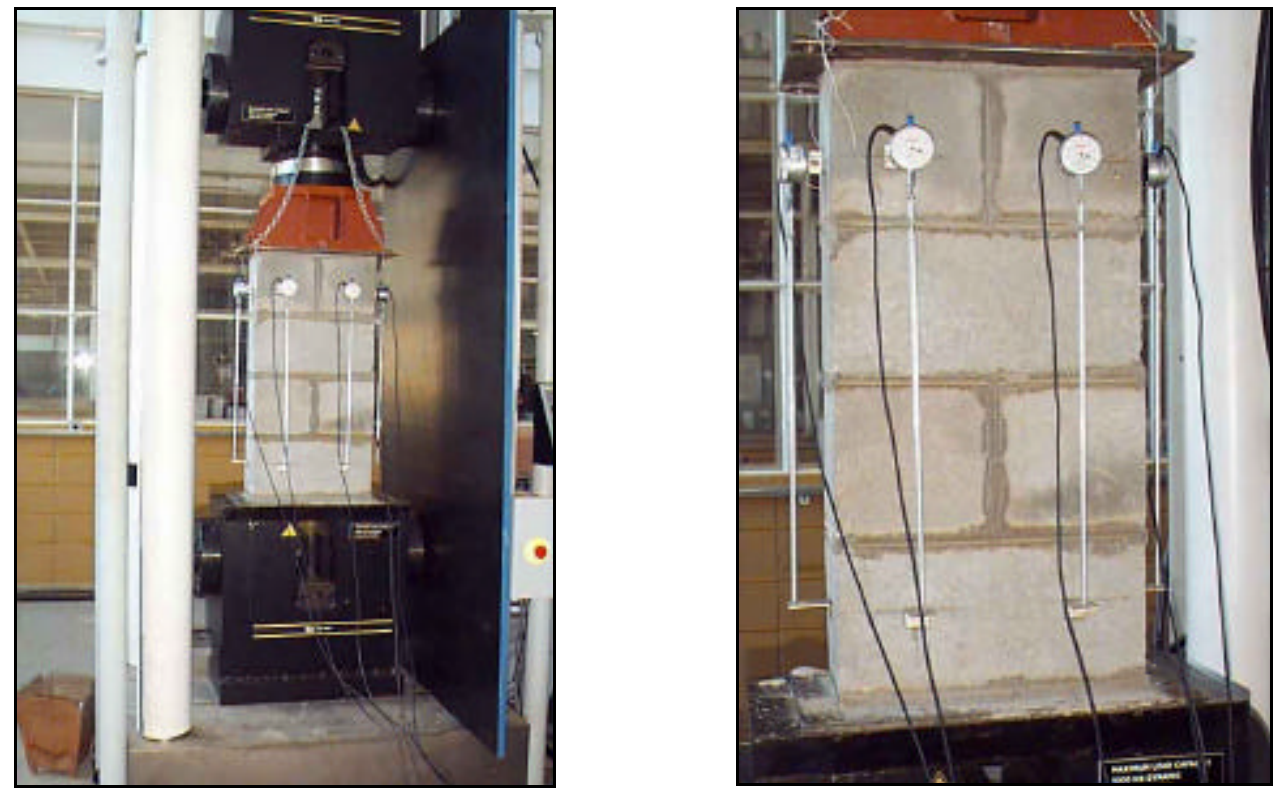

Figura 4.14 - Esquema do ensaio.

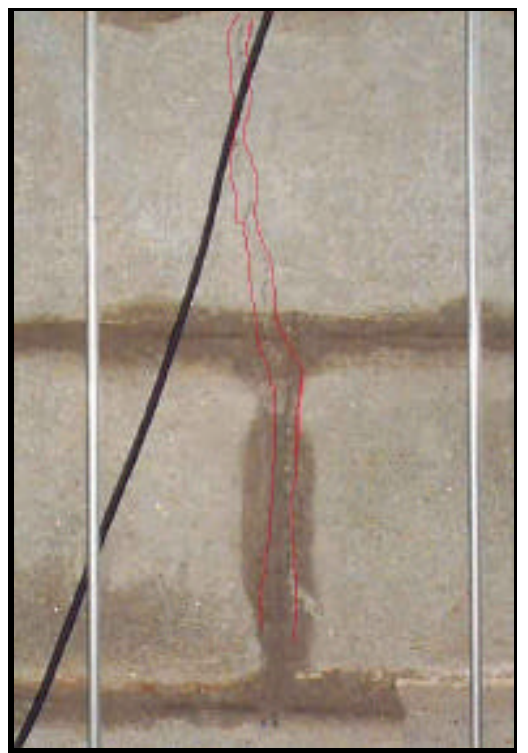

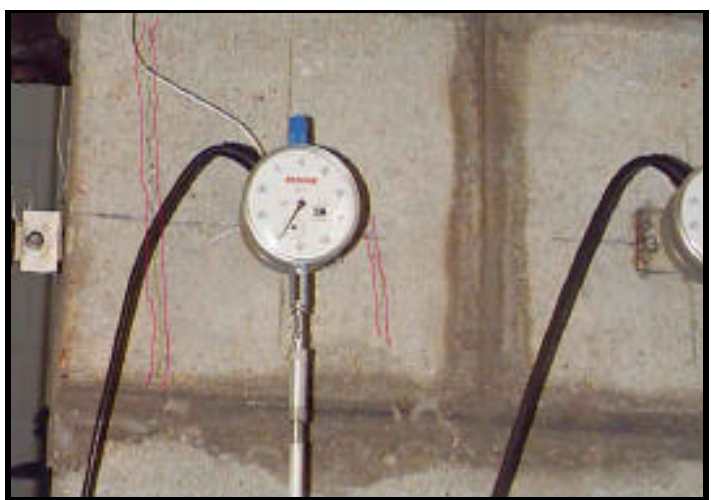

Figura 4.15 - Fissuras nos blocos.

Figura 4.16 - Fissura na argamassa prolongada no bloco.

A argamassa de assentamento utilizada foi preparada com o traço de 1:0,5:5 (ASTM C270) e apresentou resistência de $8 \mathrm{MPa}$. Durante o ensaio, a carga máxima aplicada foi de $288 \mathrm{kN}$ sendo que a primeira fissura foi observada com um carregamento de $270 \mathrm{kN}$. A fissura se apresentou verticalmente no bloco da terceira fiada. Com o aumento da carga a fissura se prolongou acompanhando a junta de argamassa, atravessando o bloco inferior. Houve também destacamento do material do bloco na parte longitudinal da parede e fissuras nos septos dos blocos. 
Analisando-se o gráfico força $\mathrm{x}$ deslocamento deste modelo observa-se que a medição do encurtamento no relógio $\mathrm{n}^{\mathrm{o}} 6$ foi prejudicada. Provavelmente isso ocorreu devido a uma fissura no septo do bloco que coincidiu com a cantoneira de apoio do relógio. Observa-se também claramente que, apesar de todos os cuidados, houve uma excentricidade no carregamento, podendo-se notar que a região onde se localizavam os relógios 4 e 5 foi mais comprimida.

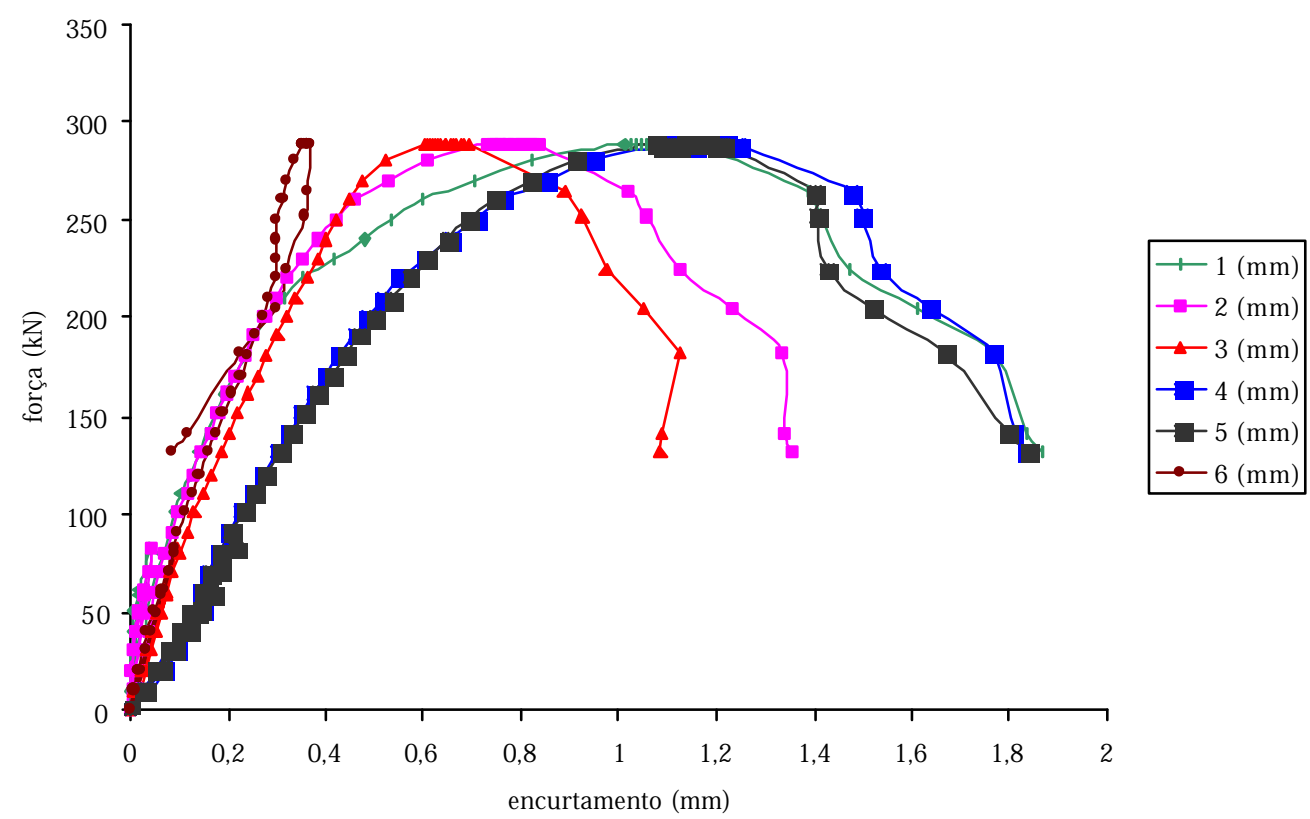

Figura 4.17 - Gráfico força x encurtamento da paredinha piloto.

Os resultados dos ensaios de blocos e prismas apresentaram valores médios de eficiência de $\eta=0,9$. A resistência à compressão dos prismas foi de $f_{p}=8 \mathrm{MPa}$ e a dos blocos de 9,5 MPa. Após este ensaio-piloto foram realizados os ensaios efetivos de paredinhas com os tipos de revestimento descritos anteriormente. Os resultados dessa série final estão descritos no Capítulo 5.

\subsubsection{Ensaios de compressão diagonal}

A outra série de ensaios programada foi a de ensaios de paredinhas submetidas à compressão diagonal em modelos com dimensões de 79 x $79 \mathrm{~cm}$. O procedimento de ensaio foi baseado na ASTM E 519 (1993) — Standard test method for diagonal 
tension (shear) in masonry assemblages — também com pequenas modificações. O aparato utilizado para aplicação da carga foi modificado para melhor distribuição do carregamento. Os furos dos blocos que ficavam em contato com as sapatas foram preenchidos por graute no traço de 1:0,1:3:1,7 para que não rompessem durante o ensaio possibilitando assim, a medição dos esforços de tração no plano médio da parede. Um outro gabarito, desta vez de madeira, foi idealizado de modo que servisse tanto para assentamento da parede como para seu transporte. O gabarito e o esquema do ensaio estão demonstrados seguir:

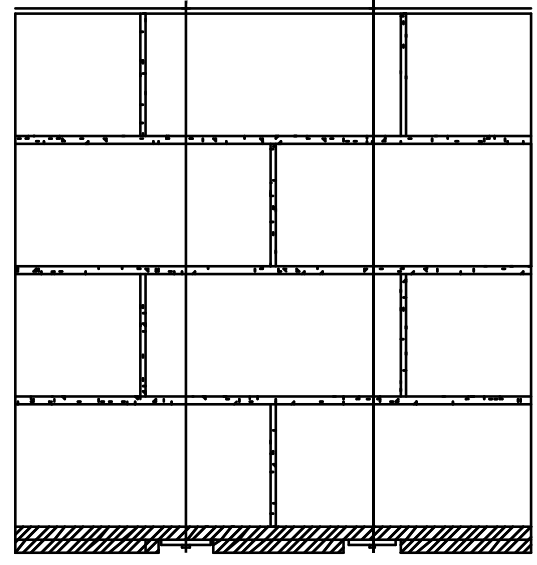

Figura 4.18 - Gabarito de madeira

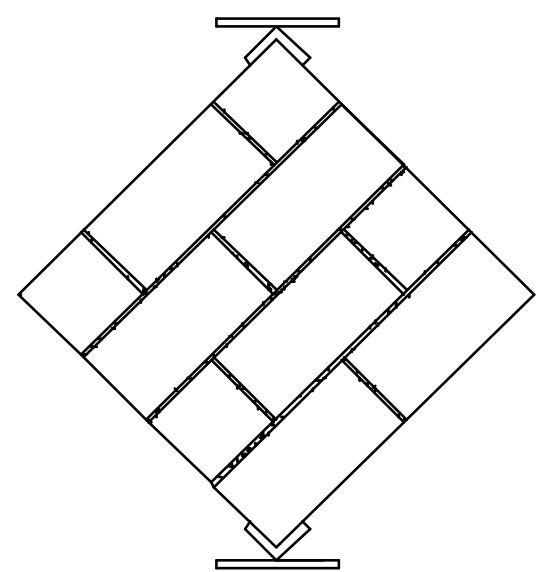

Figura 4.19 - Esquema do ensaio. para assentamento e transporte.
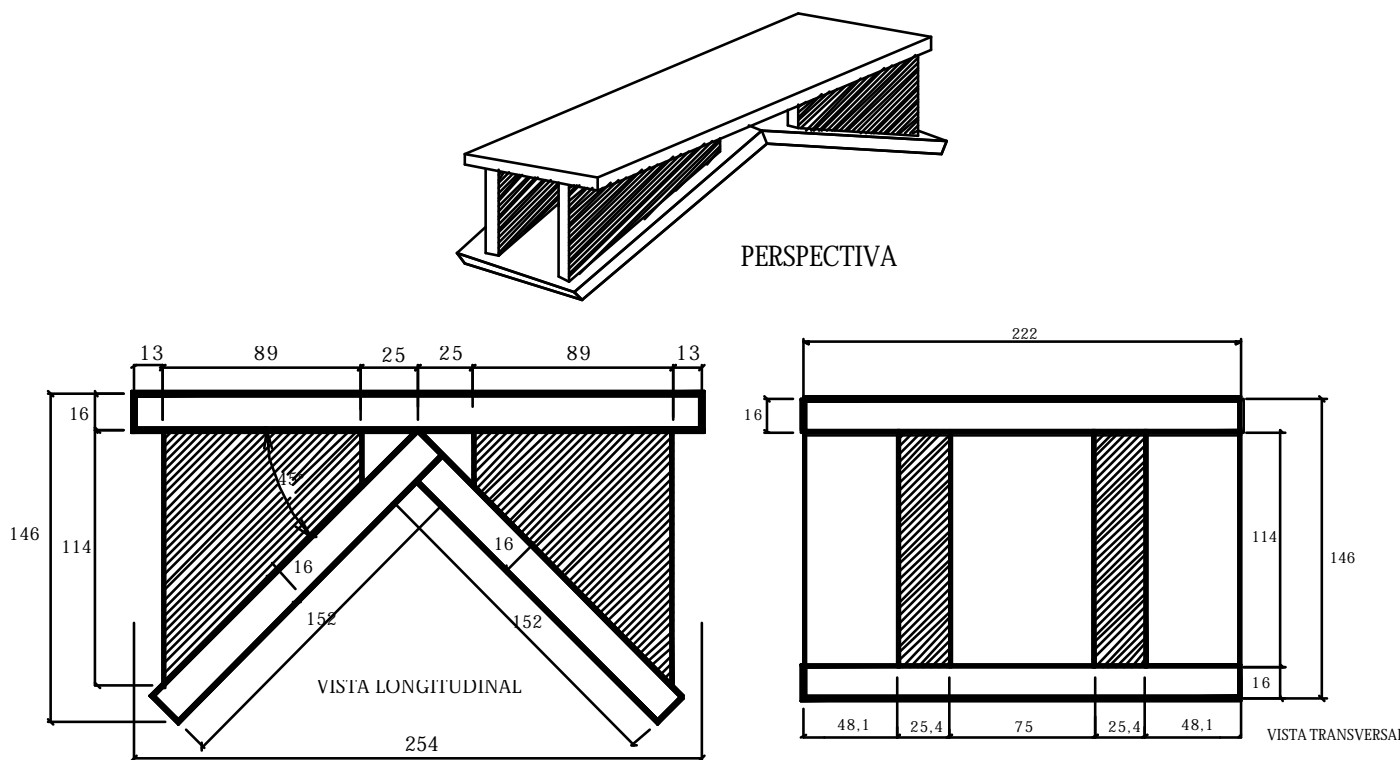

Figura 4.20 - Dimensão das sapatas.

Assim como foi realizado um ensaio-piloto da série final da compressão axial, também foi feito um ensaio-piloto de compressão diagonal. O traço da argamassa de 
assentamento foi 1:0,5:5, a qual apresentou resistência de $8 \mathrm{MPa}$ aos 28 dias. Para que a parede não sofresse nenhum tipo de dano no transporte, ela foi transportada pré-comprimida usando-se uma empilhadeira para colocá-la na posição final de ensaio.

As sapatas de aplicação de carga foram centradas na máquina de ensaio, de tal maneira a fazer coincidir a diagonal da paredinha com o eixo vertical do acionador hidráulico e assim eliminar a ocorrência de excentricidades que poderiam alterar os resultados do ensaio. Além disso, foi verificada a posição final da paredinha utilizando a régua de nível antes da fixação dos suportes para medição das deformações.

Foram medidas as deformações diagonais, tanto na vertical como na horizontal. As distâncias adotadas para medir as deformações (base de medida) tanto nas diagonais verticais como horizontais foram de $750 \mathrm{~mm}$.

A velocidade de carregamento foi de $0,002 \mathrm{~mm} / \mathrm{s}$. Não foram realizadas descargas, o carregamento foi contínuo e aplicado ao longo de uma das diagonais. Antes do transporte do modelo foi colocada massa plástica nas sapatas de apoio para regularização do seu contato com os blocos. O esquema de transporte e ensaio estão representados a seguir.

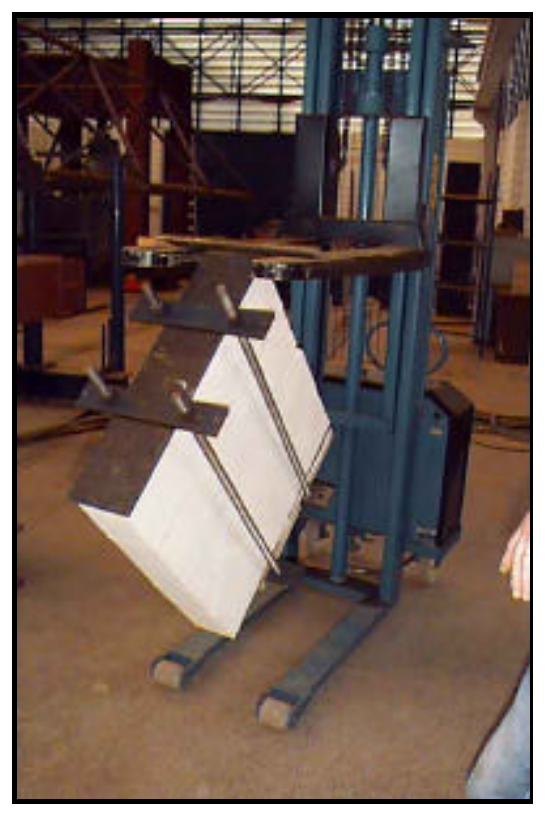

Figura 4.21 - Transporte do modelo.

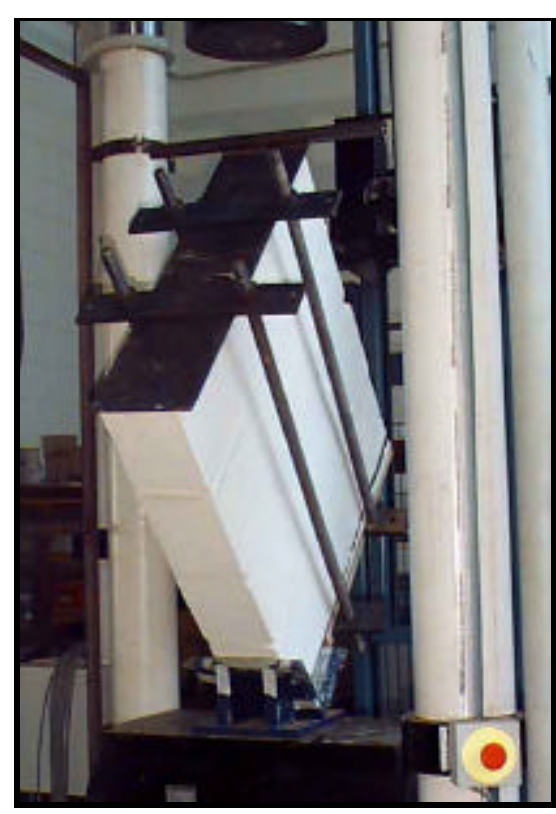

Figura 4.22 - Modelo no equipamento de ensaio. 


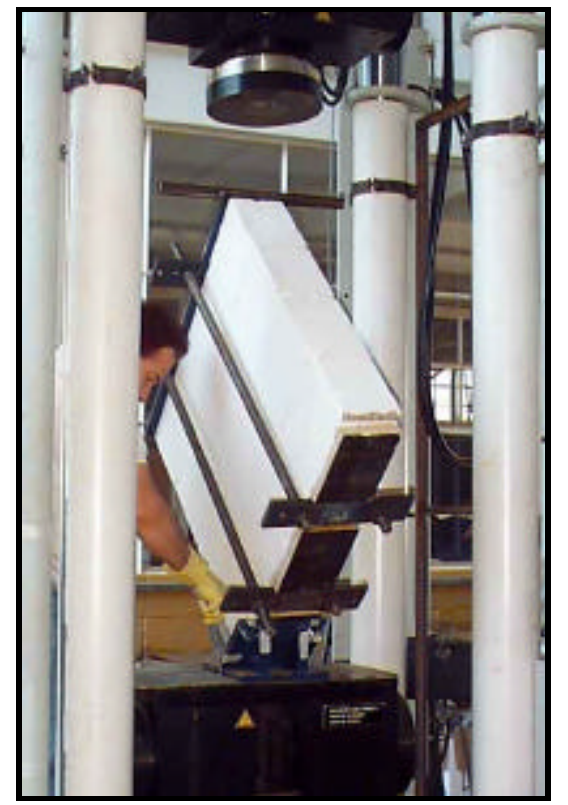

Figura 4.23 - Colocação de massa plástica na sapata de apoio.

A ruptura se deu com um carregamento de $58 \mathrm{kN}$. A forma de ruptura do modelo foi por deslocamento integral em uma das juntas horizontais. Essa forma de ruptura foi citada por alguns autores da bibliografia consultada, como SINHA e HENDRY, citados por SABBATINI (1984). Segundo estes autores o tipo de ruptura nos ensaios de compressão diagonal pode ocorrer em duas formas: por cisalhamento na interface tijolo-argamassa ou por fissuras de tração diagonal nos tijolos e juntas de argamassa. Ressaltam também que o tipo de ruptura depende das resistências relativas dos principais constituintes de alvenaria (alvenaria e argamassa).

Já PAGE (1981) relata que quando a parede está submetida às forças horizontais e verticais, fica caracterizado um estado biaxial de tensões, onde geralmente a maior tensão principal é a compressão, e a menor tensão principal é a tração. Nestas condições a alvenaria não só depende destas tensões principais, mas também de uma terceira variável, que é a orientação da junta de argamassa em relação à direção das tensões principais. Isto é característico dos materiais anisotrópicos (caso da alvenaria), devido ao fato de estar constituída por dois componentes (blocos e argamassa) com propriedades diferentes. Dependendo da orientação das juntas em relação à da tensão aplicada, a ruptura pode ocorrer só nas juntas ou de várias formas, envolvendo a argamassa e as unidades de alvenaria. 
Ressalta-se que na descrição dos ensaios finais são apresentados os cálculos da tensão de cisalhamento, deformação e módulo de rigidez utilizando-se as expressões recomendadas pela norma ASTM E-519. O gráfico força x deslocamento do ensaiopiloto realizado está apresentado a seguir.

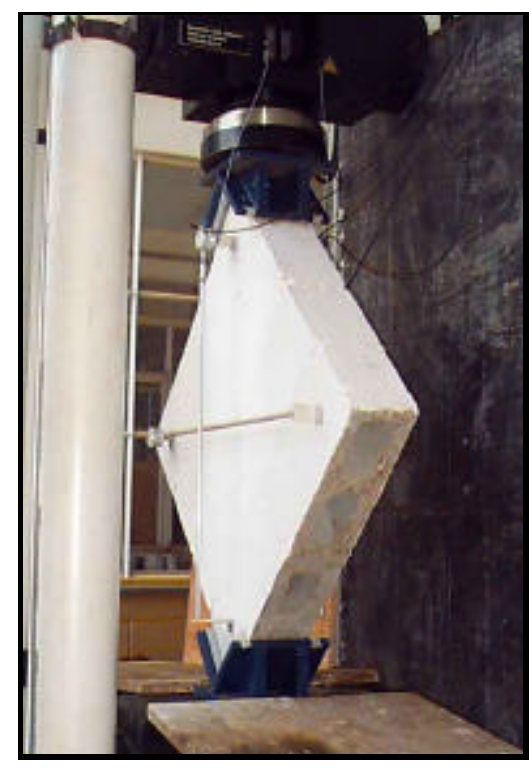

Figura 4.24 - Esquema do ensaio.

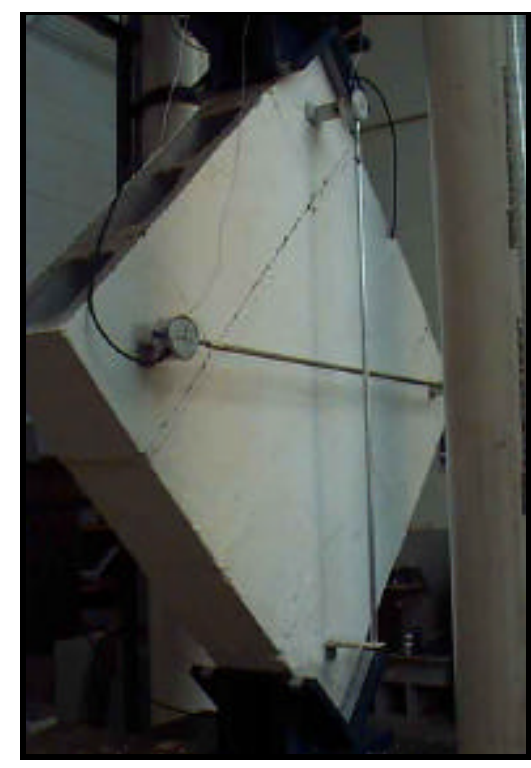

Figura 4.25 - Ruptura na interface tijoloargamassa.

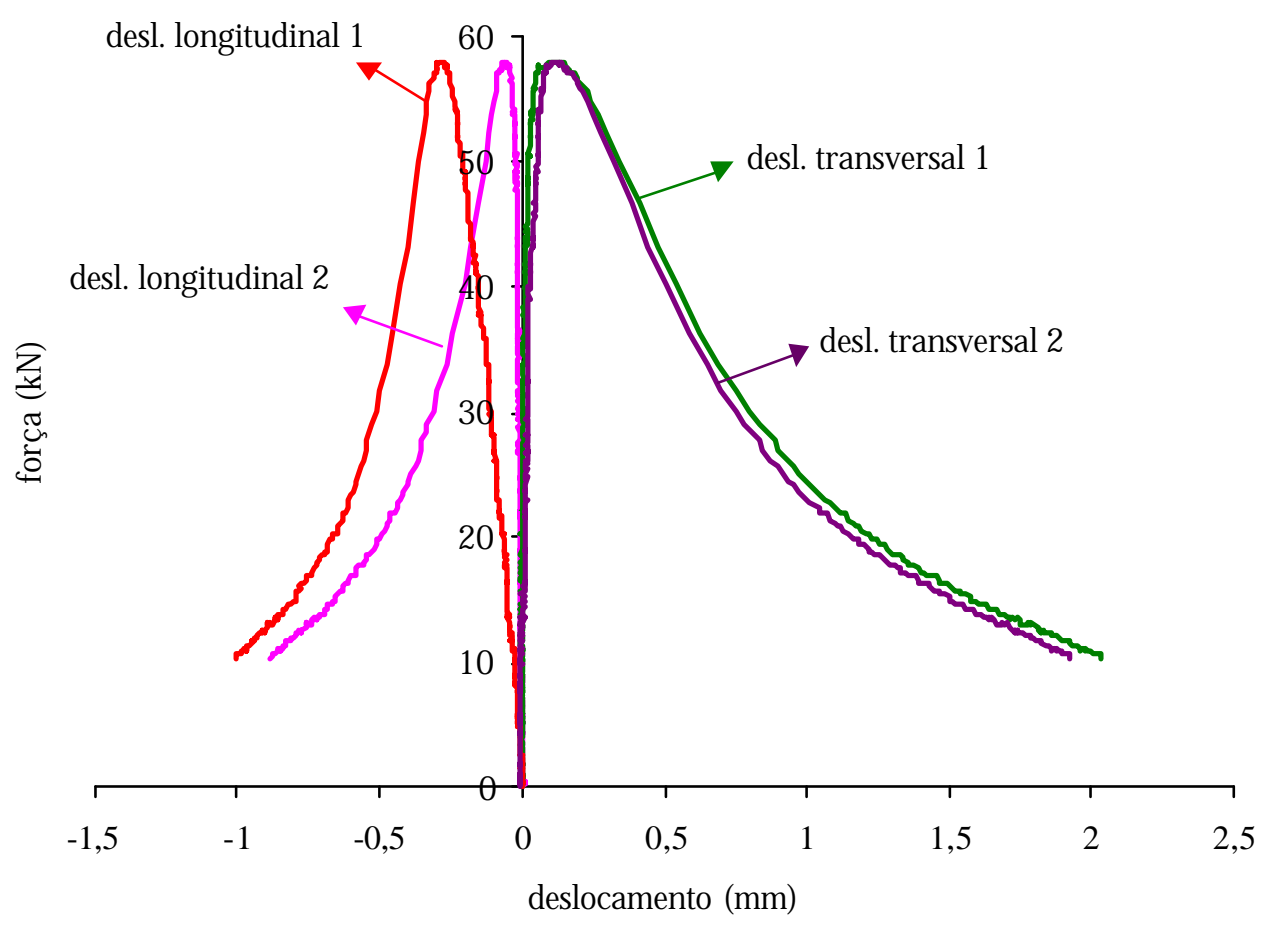

Figura 4.26 - Gráfico força x deslocamento da paredinha piloto. 
Após este ensaio-piloto foram realizados os ensaios efetivos de paredinhas com os tipos de revestimento descritos anteriormente. Os resultados dessa série final estão descritos no Capítulo 6.

\subsubsection{Ensaio de flexão}

Os ensaios de flexão foram realizados em paredes com dimensões de 80 x 160 $\mathrm{cm}$. Optou-se por fazer um cálculo teórico para a parede sem revestimento que serviria de referência para as demais paredes revestidas. Os revestimentos utilizados foram apenas os revestimentos com telas de aço soldadas, nas mesmas combinações usadas nas séries de compressão axial e compressão diagonal. Foram confeccionados dois modelos de cada tipo de revestimento, totalizando seis modelos analisados. Os ensaios foram baseados na norma NBR 14322 - Paredes de alvenaria estrutural - verificação da resistência à flexão simples ou à flexo-compressão.

Os primeiros modelos foram ensaiados aplicando-se a carga no meio do vão (situação 1). Como se observou um comportamento satisfatório durante o ensaio e a ruptura se dava por flexão, o esquema de ensaio foi modificado. O carregamento foi colocado nos terços do vão dos apoios (situação 2) tentando-se forçar a ruptura por cisalhamento e verificar se haveria o escorregamento das placas de revestimento. $\mathrm{O}$ esquema dos ensaios realizados estão representados nas Figura 4.27 e Figura 4.28. Os resultados dessa série final estão descritos no Capítulo 7.

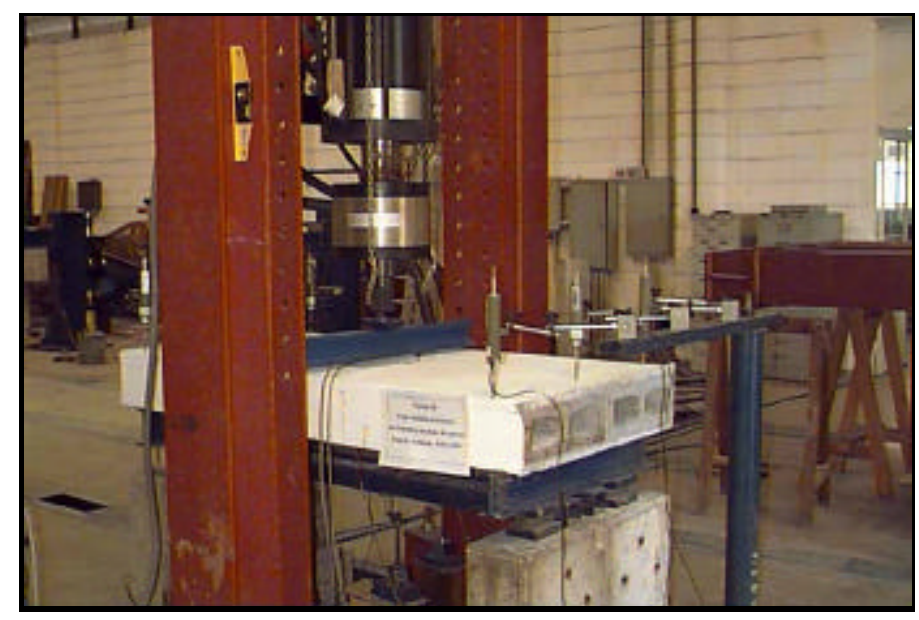

Figura 4.27 - Ensaio com carga aplicada no vão. 


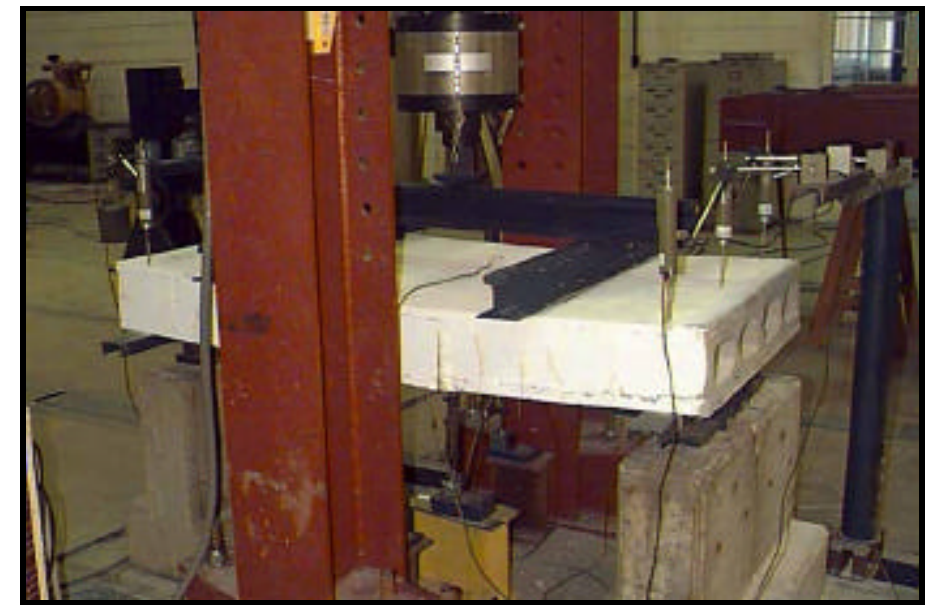

Figura 4.28 - Ensaio com carga aplicada nos terços do vão.

Depois de realizadas as séries de ensaios de paredinhas submetidas à compressão axial, compressão diagonal e flexão pôde-se observar os principais fenômenos ocorridos e analisar alguns parâmetros importantes como a resistência, a fissuração, a forma de ruína e o comportamento pós-pico.

\subsubsection{Ensaios de protótipos com abertura}

Após a realização de ensaios de compressão axial, compressão diagonal e flexão foi então idealizada uma série de ensaios que consistiu de painéis com dimensões de $180 \times 200 \mathrm{~cm}$ e uma abertura de $80 \times 60 \mathrm{~cm}$ (Figura 4.29), os quais foram submetidos a forças distribuídas numa região pequena do topo da parede. Foram ensaiados painéis em três situações diferentes: paredes íntegras, reabilitadas e reforçadas.

A decisão de ensaiar painéis com aberturas se deu pela intenção de criar situações de desvio de tensões no plano da parede, provocando esforços de compressão, tração e cisalhamento. Nestas situações, pretende-se observar a eficiência de um dos tipos de revestimento (em particular, aquele em que se usa telas soldadas) na reabilitação e melhoria do desempenho de paredes em condições próximas às dos casos reais. 


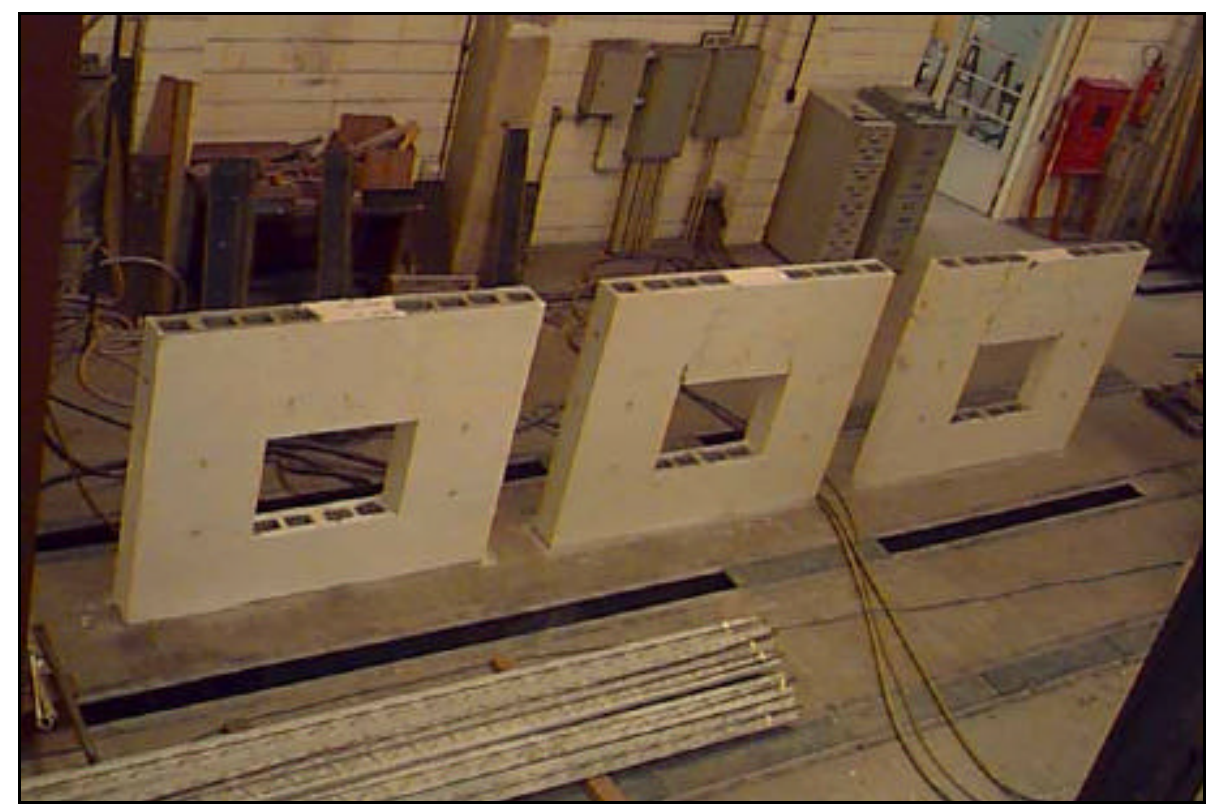

Figura 4.29 - Vista dos protótipos com abertura.

Para determinação do tamanho dos protótipos, carregamento a ser aplicado, instrumentação do modelo e conhecimento do comportamento provável de ruptura, foram realizadas análises numéricas simplificadas em painéis com as mesmas dimensões e características mecânicas que pudessem simular aproximadamente os modelos a serem ensaiados. Enfatiza-se mais uma vez que a análise numérica realizada nesta parte do trabalho, com auxílio do programa computacional ANSYS 5.5, tem por objetivo tão somente observar a distribuição de tensões e a ordem de grandeza dos esforços que surgem nas paredes íntegras ou danificadas, submetidas a diversos tipos de solicitação. Ressalva-se também mais uma vez que neste projeto de pesquisa enfatiza-se a obtenção de dados experimentais, e portanto, na comparação dos resultados experimentais com os resultados teóricos, os valores numéricos não servirão para calibração de modelos teóricos, mas deverão ser considerados na análise comportamental dos modelos estudados.

\subsection{Análise teórica}

\subsubsection{Comportamento de paredes submetidas à compressão axial}

Como se sabe, a boa resistência à compressão axial das paredes de alvenaria é uma das principais características que tornam atrativo o sistema construtivo de 
paredes portantes. No entanto, a previsão da capacidade portante de uma simples parede de alvenaria é uma tarefa complexa que envolve uma boa dose de empirismo.

Embora tenham havido grandes avanços no conhecimento teórico do comportamento das estruturas de alvenaria, a tecnologia ainda carece de metodologias de cálculo mais refinadas que permitam, como no caso do presente trabalho, uma análise de resultados experimentais mais elucidativa. Assim, espera-se que a discussão apresentada no Capítulo $\mathbf{5}$ venha trazer novos elementos a este assunto.

Tal complexidade na análise teórica do comportamento de uma parede submetida à compressão axial deve-se, resumidamente, aos seguintes aspectos particulares:

a) os blocos de alvenaria (cerâmicos, ou de concreto, como é o caso desta pesquisa) são constituídos de material de comportamento não-linear e sujeitos à micro e à macrofissuração. Embora esses materiais possam apresentar comportamento elástico-linear em condições de baixa solicitação, eles passam a perder progressivamente a resistência e a rigidez à medida que se aumenta a solicitação. No limite da sua capacidade resistente, a ruína se dá pela instabilidade que acontece internamente ao corpo de tais materiais, ocorrendo descontinuidades e grandes deslocamentos entre os fragmentos de material. Após atingida a resistência máxima, o comportamento do material e a sua tenacidade passam a depender das ligações internas ainda existentes que possam proporcionar resistência residual e capacidade de absorção de energia;

b) como os blocos são peças separadas, que nas paredes são montadas e unidas por meio de camadas de argamassa de assentamento, estas também interferem no comportamento do conjunto, isto é, a parede é um elemento estrutural composto, constituído de diferentes materiais, que atuam em distintas condições de tamanho, disposição e condições de solicitação e deformação;

c) a resistência de uma parede não fica diretamente condicionada à resistência da argamassa de assentamento medida em ensaios de compressão axial, porque ela, na parede, trabalha em camadas de pequena espessura que sofrem o efeito positivo do confinamento. Assim, numa parede de alvenaria sujeita à compressão 
axial, a argamassa de assentamento é comprimida na direção do carregamento e sofre uma expansão lateral, a qual é restringida pelas tensões de aderência com os blocos. Nestas condições, sob pressões de confinamento lateral ela apresenta uma resistência superior àquela medida em corpos-de-prova não confinados. Ao mesmo tempo, os blocos são solicitados por tensões de tração transversais correspondentes a estas mesmas pressões de confinamento;

d) as juntas verticais podem introduzir focos de concentração de tensões e também constituir caminhos preferenciais para a fissuração;

e) outro aspecto a ser observado é que os blocos podem ser vazados, como é o caso dos blocos utilizados neste trabalho, que têm vazamentos verticais. Além de exigir as devidas considerações no cálculo da deformabilidade, este fato introduz uma complexidade ainda maior no comportamento estrutural de uma parede, porque os blocos passam a ser constituídos de partes delgadas, influindo a capacidade resistente, e as áreas de contato entre bloco e argamassa ficam mais reduzidas;

f) no caso de blocos vazados, como a superfície de contato com a argamassa de assentamento é menor, o efeito de concentração tensões é maior, assim como as conseqüências de falhas localizadas de assentamento e de materiais estranhos na argamassa de assentamento, o que pode levar a uma ruptura prematura. É de se supor também que os mecanismos de redistribuição de tensões sejam menos eficientes e que a ruptura de uma parede de blocos vazados seja menos dúctil do que a de uma parede de blocos maciços de menor resistência;

g) a capacidade resistente de uma parede passa então a ser determinada por um conjunto de fatores que não são necessariamente independentes entre si, o que torna a sua previsão complexa, como já se afirmou. A ruína pode se dar pelo fendilhamento dos septos transversais dos blocos (no caso de vazamentos verticais), pelo fendilhamento dos blocos na face maior da parede ou ainda pelo esmagamento ou cisalhamento da argamassa de assentamento. Se, por um lado, os materiais constituintes (concreto ou cerâmica dos blocos e argamassa de assentamento) estão sujeitos a instabilidades da sua estrutura interna, os componentes (blocos e camadas de argamassa de assentamento) também podem 
atingir condições de instabilidade, inclusive antes mesmo de se atingir a resistência potencial dos materiais. Por exemplo, se ocorrer o fendilhamento dos septos transversais em todo o plano da parede, de tal forma que as duas faces percam a ligação entre si, pode ocorrer a instabilidade dessas faces;

h) portanto, a capacidade resistente de uma parede de alvenaria sob compressão axial é menor do que o produto da resistência do material dos blocos pela sua área líquiida, mas ela pode, mesmo no caso de argamassa de assentamento menos resistentes qu o material dos blocos, ser maior do que o produto da resistência da argamassa de assentamento pela sua área líquiida. Para o cálculo da capacidade resistente de uma parede de alvenaria, o procedimento indicado pela NB-10837 introduz a resistência obtida em ensaios de prismas, que já leva em conta o comportamento conjunto dos blocos e da argamassa de assentamento, como se mostra na expressão a seguir. Nesta expressão, considera-se também um coeficiente de segurança igual a 5 e o efeito da esbeltez da parede, que de certa forma representa a sensibilidade do elemento a esforços de flexão e a efeitos de segunda ordem:

$$
\mathrm{P}_{\mathrm{adm}}=0,20 \mathrm{f}_{\mathrm{p}}\left[1-\left(\frac{\mathrm{h}}{40 \mathrm{t}}\right)^{3}\right] \mathrm{A}
$$

onde:

$$
\begin{aligned}
& \mathrm{P}_{\mathrm{adm}} \rightarrow \text { a carga vertical de compressão atuante; } \\
& \mathrm{f}_{\mathrm{p}} \rightarrow \text { resistência a compressão do prisma; } \\
& \mathrm{f}_{\mathrm{alv}, \mathrm{c}}=0,20 \mathrm{f}_{\mathrm{p}} \mathrm{R} \rightarrow \text { tensão de compressão axial atuante; } \\
& \mathrm{R}=1-\left(\frac{\mathrm{h}}{40 \mathrm{t}}\right)^{3} \rightarrow \text { fator de redução da resistência associado à esbeltez }
\end{aligned}
$$
(h/t), aplicável também à alvenaria armada.

i) de acordo com essa indicação da norma, a resistência de uma parede é menor do que a resistência do prisma, que por sua vez é menor do que a resistência do bloco; 
Pode-se dizer, a grosso modo, que uma parede de alvenaria submetida à compressão axial comporta-se como um elemento composto de diferentes componentes (blocos e camadas de argamassa) associados em série. Numa primeira aproximação, pode-se dizer que a deformabilidade de uma parede é dada pelo modelo de Reuss (MEHTA \& MONTEIRO, 1993):

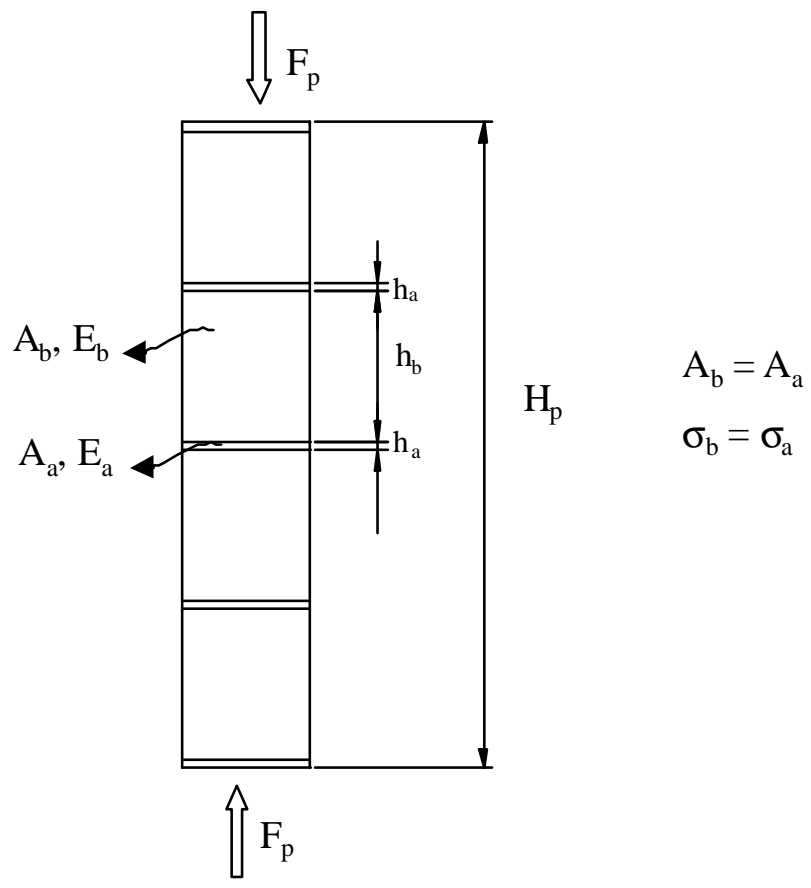

Figura 4.30 - Representação do Modelo de Reuss.

Como:

$$
\sigma=\varepsilon_{\mathrm{b}} \mathrm{E}_{\mathrm{b}}=\varepsilon_{\mathrm{a}} \mathrm{E}_{\mathrm{a}} \quad \text { e } \quad \Delta \mathrm{h}_{\mathrm{p}}=\Delta \mathrm{h}_{\mathrm{b}}+\Delta \mathrm{h}_{\mathrm{a}}=\mathrm{h}_{\mathrm{b}} \varepsilon_{\mathrm{b}}+\mathrm{h}_{\mathrm{a}} \varepsilon_{\mathrm{a}}
$$

Tem-se:

$$
\frac{H_{p}}{E_{p}}=\frac{h_{b}}{E_{b}}+\frac{h_{a}}{E_{a}}
$$

Ou ainda em termos de volume tem-se:

$$
\frac{V_{p}}{E_{p}}=\frac{V_{b}}{E_{b}}+\frac{V_{a}}{E_{a}}
$$

Sabe-se, no entanto, que o modelo de Reuss na forma apresentada não é capaz de reproduzir fielmente as condições de deformação da parede, pelo fato de que há 
juntas verticais entre os blocos e que a argamassa de assentamento já colocada não tem as mesmas propriedades medidas em corpos-de-prova. Além disso, tanto o material dos blocos como a argamassa de assentamento não apresentam comportamento linear. Todavia, o modelo de associação em série é ilustrativo da associação de blocos e camadas de argamassa e pode dar uma indicação da deformabilidade de uma parede nos primeiros estágios de carregamento, ou ainda, de estágios intermediários em serviço, se forem adotados valores de módulos de elasticidade secantes à $40 \%$ da tensão máxima.

Quando se acrescenta a uma parede de alvenaria revestimentos resistentes em ambas as faces, está se introduzindo mais um componente, que de alguma forma modificará o comportamento do elemento composto já existente. De modo também grosseiro, pode-se dizer que uma parede de alvenaria revestida corresponde a uma associação em série de blocos e camadas de argamassa de assentamento, a qual se associa em paralelo com chapas de argamassa de revestimento. Lembrando-se que o núcleo é considerado um material contínuo.

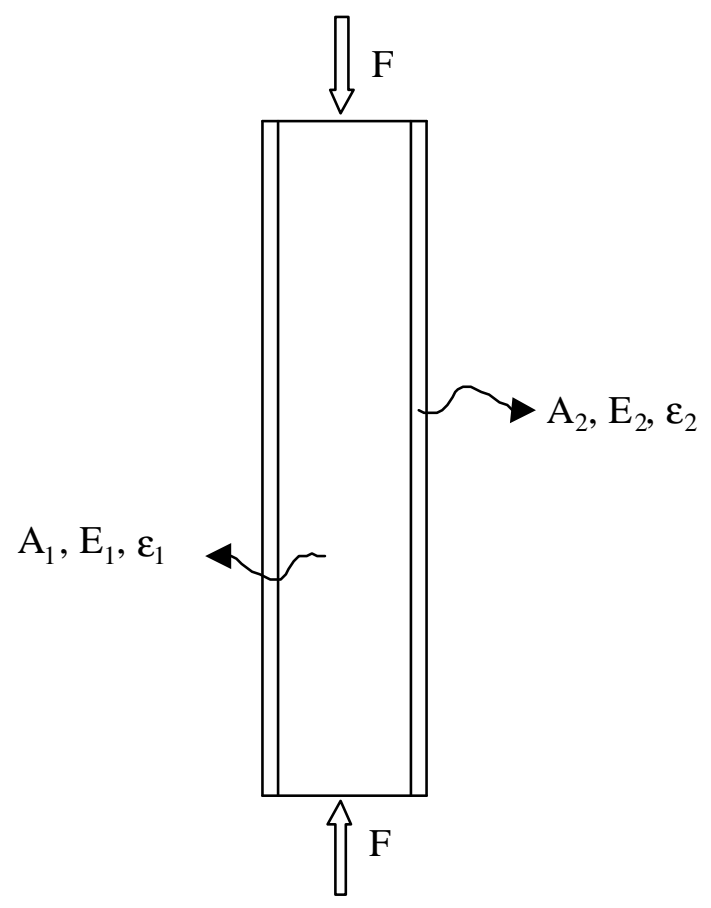

Figura 4.31 - Representação do modelo de Voigt. 
Como uma primeira aproximação, pode-se tentar estimar as propriedades de deformabilidade de uma parede de alvenaria empregando-se o modelo de Voigt (MEHTA \& MONTEIRO, 1993). Considerando o elemento composto tem-se:

$$
\begin{array}{lcc}
\mathrm{F}=\mathrm{F}_{1}+\mathrm{F}_{2} & \text { e } & \varepsilon=\varepsilon_{1}=\varepsilon_{2} \\
\varepsilon=\frac{\mathrm{o}_{\mathrm{eq}}}{\mathrm{E}_{\mathrm{eq}}} & \text { e } & \sigma_{\mathrm{eq}}=\frac{\mathrm{F}}{\mathrm{A}_{1}+\mathrm{A}_{2}}
\end{array}
$$

Logo:

$$
\mathrm{E}_{\mathrm{eq}}=\frac{\mathrm{E}_{1} \mathrm{~A}_{1}+\mathrm{E}_{2} \mathrm{~A}_{2}}{\mathrm{~A}_{1}+\mathrm{A}_{2}}
$$

É preciso lembrar, no entanto, que as propriedades dos materiais dos componentes não são variáveis independentes, pois:

a) a argamassa de assentamento influi na fissuração do bloco e aumenta portanto a sua deformabilidade;

b) o bloco introduz tensões de confinamento na argamassa de assentamento e portanto torna-a menos deformável que a argamassa moldada no corpo-de-prova;

c) o revestimento está aderido de forma diferenciada aos blocos e à camada de argamassa e isso altera o comportamento do conjunto;

d) a resistência da argamassa projetada não é a mesma medida nos ensaios de corpos-de-prova cilíndricos, por causa do processo de aplicação. É de se esperar que a resistência da argamassa projetada seja menor quando a técnica de projeção for menos eficiente, como é o caso das paredes neste trabalho, em que a argamassa foi aplicada manualmente com colher-de-pedreiro;

e) por outro lado, os materiais da parede são porosos e tendem a absorver água da argamassa de revestimento. Isto tende a aumentar a resistência da argamassa;

f) finalmente, as condições de cura da argamassa de revestimento nem sempre são as ideais, dada a grande superfície exposta e os inconvenientes de aplicação de água sobre as paredes, mesmo em laboratório. 


\subsubsection{Compressão diagonal}

O ensaio de compressão diagonal baseia-se num conceito semelhante ao dos ensaios tipo "split test", ou seja, de avaliação da resistência à tração por compressão transversal. Este conceito é empregado, por exemplo, na determinação da resistência à tração do concreto em ensaios de compressão diametral de corpos-de-prova cilíndricos.

No caso de paredes de alvenaria, conforme a ASTM E-519, este ensaio é utilizado também para avaliar a resistência ao cisalhamento. O estado de solicitação causado pelas forças de compressão diagonalmente opostas leva ao aparecimento de tensões principais $\sigma_{1}$ de tração em toda a parte central da parede e tensões principais $\sigma_{2}$ nulas. As tensões de cisalhamento surgem, portanto, com o seu valor máximo em direções a $45^{\circ}$, ou seja, paralelas às bordas da parede. Na Figura 4.32 e Figura 4.33 ilustra-se a distribuição das tensões $\sigma_{1}$ e $\tau_{\mathrm{xy}}$, respectivamente, no plano da parede, as quais foram obtidas em simulação feita sobre elemento plano (PLANE 42) e isotrópico com uso do programa ANSYS 5.5.

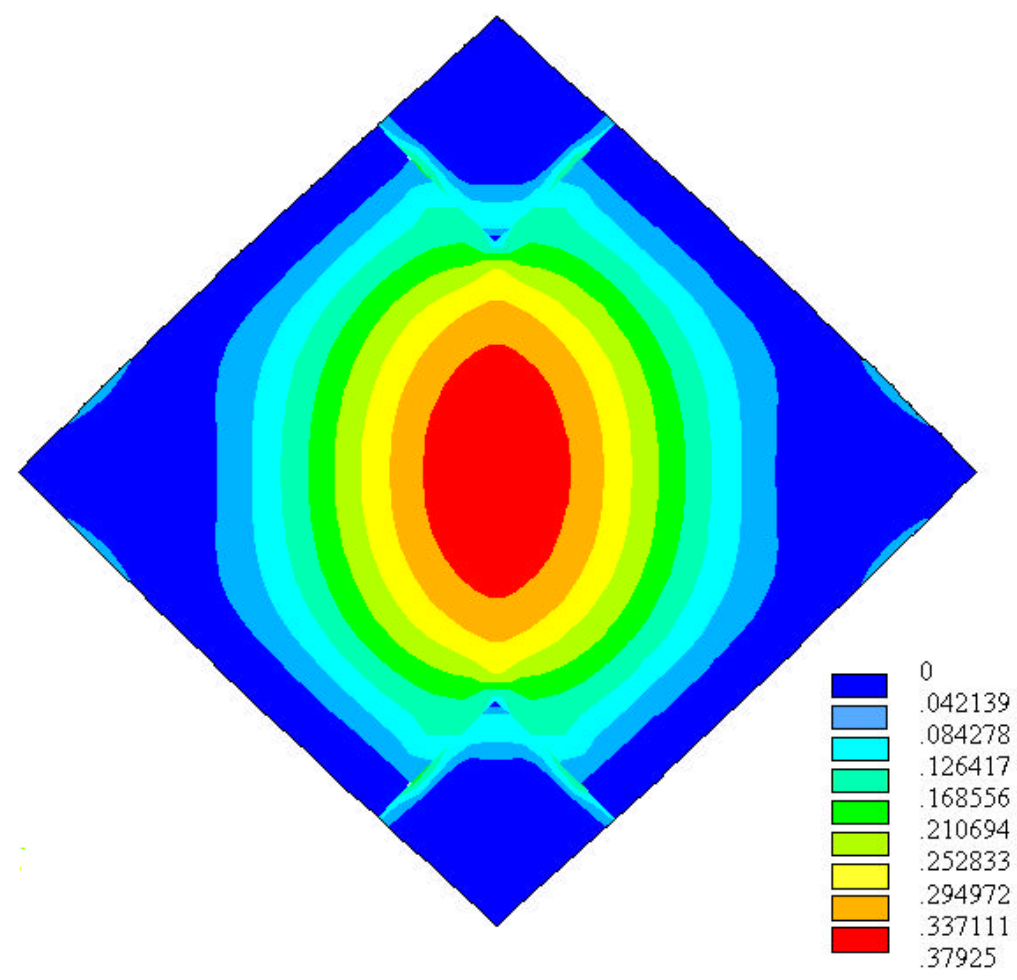

Figura 4.32 - Distribuição das tensões principais $\sigma_{1}\left(\mathrm{kN} / \mathrm{cm}^{2}\right)$ 


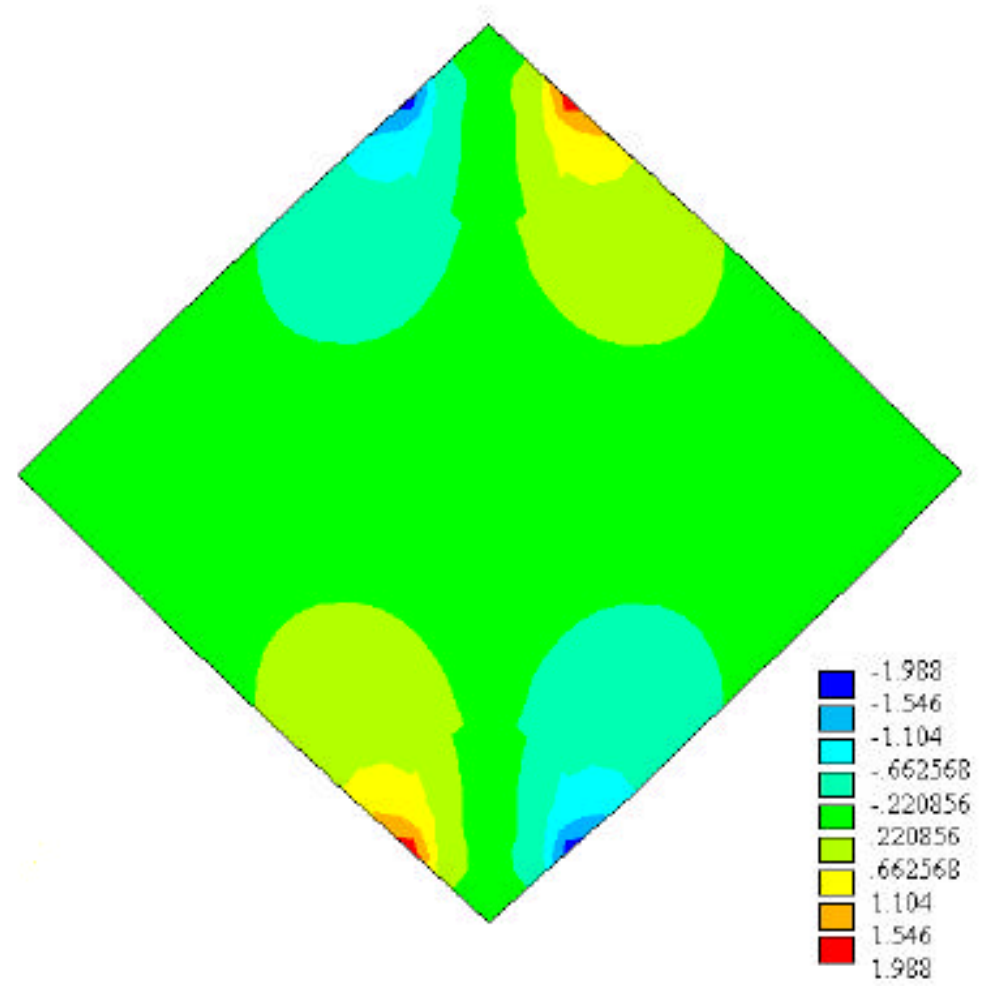

Figura 4.33 - Distribuição das tensões $\tau_{\mathrm{xy}}\left(\mathrm{kN} / \mathrm{cm}^{2}\right)$

Basicamente, dois tipos de ruptura podem ser esperados neste tipo de ensaio: a ruína por escorregamento dos blocos ao longo das camadas de assentamento, que se encontram a $45^{\circ}$ em relação à direção das forças aplicadas, e a ruína por tração diagonal, com o surgimento de fissuras verticais (que portanto cortarão diagonalmente os blocos) na parte central da parede.

A introdução de revestimentos resistentes certamente aumentará a capacidade resistente da parede, especialmente no caso de paredes armadas com telas soldadas. A análise dos resultados dos ensaios deverá revelar as alterações do modo de ruína e o acréscimo de resistência dado pelo aumento da área de seção transversal e a adição de armaduras.

\subsubsection{Flexão simples}

Os ensaios de flexão simples foram efetuados com o objetivo de se obter dados sobre o comportamento resistente de paredes revestidas submetidas a cargas perpendiculares ao seu plano. 
A metodologia de análise teórica dos resultados deste tipo de ensaio basicamente será a mesma empregada nas estruturas de concreto armado, considerando-se as particularidades do elemento estrutural composto.

Os resultados dessa análise são apresentados e discutidos no Capítulo 7.

\subsubsection{Análise numérica}

Desde o início deste trabalho de pesquisa foram realizadas várias análises em blocos, prismas e paredinhas. Inicialmente foram realizadas análises em blocos vazados com elementos sólidos submetidos à compressão axial. Com essas análises já se encontrou problemas como a não-uniformidade e assimetria das tensões. Foi então utilizado carregamento equilibrado para que os resultados fossem coerentes. A mesma tentativa foi realizada em prismas.

Partiu-se então para análises não-lineares em paredinhas, nas quais também se encontrou problemas de consistência. Atualmente pode-se dizer que a pretensão nessas tentativas foi inicialmente muito otimista, já que no programa utilizado não havia um critério de ruptura adequado à alvenaria, além da complexidade dos fenômenos e materiais envolvidos, como já se comentou no item anterior.

Como desde o início do plano pretendia-se realizar uma análise teórica simplificada, foram realizadas algumas modificações para as análises definitivas como o elemento utilizado (elemento sólido para paredes solicitadas à compressão axial e elemento plano para as paredes com abertura), tipo de análise considerada (linear) e propriedades dos materiais adotadas (módulo de elasticidade e coeficiente de Poisson).

A seguir, apresentam-se alguns dados gerais sobre os recursos utilizados nas análise numéricas incluídas no Capítulo 5 e Capítulo 8.

As simulações numéricas analisadas foram feitas em modelos com dimensões semelhantes às dos modelos ensaiados. A análise foi feita no regime elástico, através do Programa Computacional ANSYS 5.5 fundamentado no Método dos Elementos Finitos.

Para a simulação das paredinhas ensaiadas à compressão axial foi escolhido inicialmente, o elemento SOLID 95 usado para modelos tridimensionais de estruturas sólidas. O elemento é definido por 20 nós tendo 3 graus de liberdade em cada nó: 
translações nodais $\boldsymbol{x}, \boldsymbol{y}$ e $\boldsymbol{z}$ (Figura 4.34). Este elemento foi testado nas análises dos blocos e prismas. Segundo o manual do programa, os elementos que possuem nós intermediários não devem ser utilizados em análises não-lineares (pretensão inicial do trabalho) pois, a malha gerada tende a se distorcer. Utilizou-se também o elemento SOLID 65 (8 nós), este elemento se difere do SOLID 95 apenas pelo número de nós mas, pela bibliografia consultada constatou-se que os elementos sólidos com oito nós não apresentam bons resultados. Por isso tomou-se o cuidado de discretizar um malha bem refinada para se alcançar bons resultados entre os dois elementos utilizados. Sendo assim, obteve-se valores equivalentes de tensões entre os elementos de 8 e 20 nós e optou-se por realizar as análises com o elemento SOLID 65 (Figura 4.35) pela maior facilidade de execução.

Nessa análise foram consideradas diferentes propriedades de materiais para bloco, argamassa de assentamento e argamassa de revestimento, como também, valores equivalentes de módulos de elasticidade considerando a alvenaria como um único material (bloco + argamassa) . Os valores dessas propriedades foram obtidas experimentalmente em ensaios de blocos e corpos-de-prova da argamassa de assentamento e de revestimento.

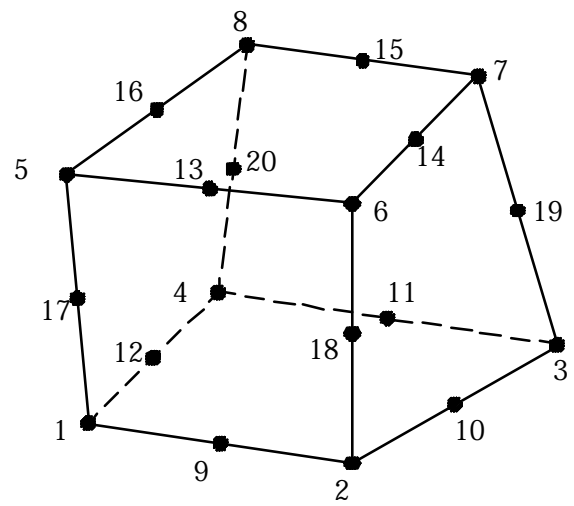

Figura 4.34 - Elemento SOLID 95

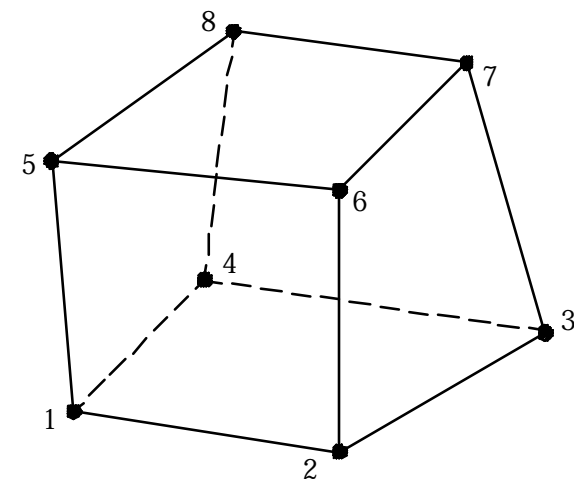

Figura 4.35 - Elemento SOLID 65

Foram também realizadas várias análises em diferentes tipos de protótipos para decisão do tamanho, instrumentação e carregamento a ser empregado nos ensaios de paredes com abertura. As simulações numéricas foram efetuadas em modelos com dimensões semelhantes às dos protótipos que iriam ser ensaiados. A análise foi feita no regime elástico utilizando-se um elemento bidimensional PLANE 42 (Figura 
4.36). O elemento escolhido para análise possui 4 nós com 2 graus de liberdade em cada nó (deslocamentos na direção $x$ e y). As propriedades dos materiais utilizadas nessas análises referem-se ao conjunto da parede (bloco + argamassa) considerando-

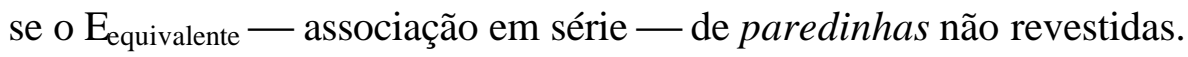

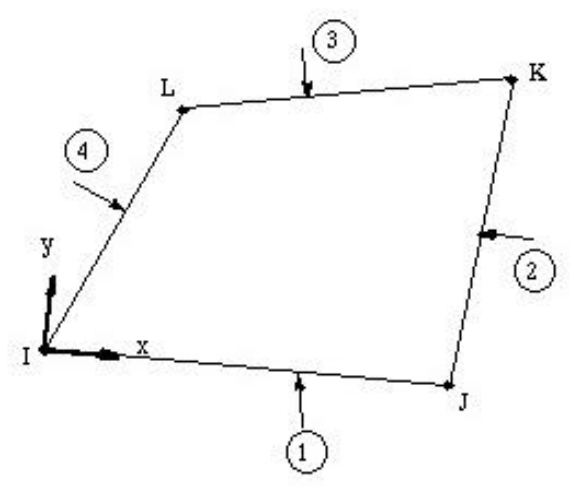

Figura 4.36 - Elemento bidimensional PLANE 42.

De modo geral, em todas as análises considerou-se $\boldsymbol{X}$ o eixo horizontal (ao longo do comprimento da parede) e $\boldsymbol{Y}$ o eixo vertical (ao longo da altura da parede) e z (ao longo da espessura) adotando-se a origem no vértice inferior esquerdo. As placas de ensaio foram consideradas infinitamente rígidas, restringindo-se os nós da base nas direções $\mathbf{x}, \mathbf{y}$ e $\mathbf{z}$; e no topo, nos nós onde o carregamento foi aplicado, estabeleceu-se restrição nas direções $\boldsymbol{x}$ e $\boldsymbol{z}$, mantendo-se os demais nós sem restrição. 